\author{
UNIVERSIDADE DE SÃO PAULO \\ FACULDADE DE ZOOTECNIA E ENGENHARIA DE ALIMENTOS
}

\title{
CELI APARECIDA CARDOSO
}

Avaliação de danos induzidos em ratos Wistar (Rattus norvergicus) expostos ao extrato aquoso de neem (Azadirachta indica) em mesmas concentrações utilizadas na lavoura de milho (Zea mays) para o controle da lagarta do cartucho (Spodoptera frugiperda).

Pirassununga/SP 


$$
\text { UNIVERSIDADE DE SÃO PAULO }
$$

FACULDADE DE ZOOTECNIA E ENGENHARIA DE ALIMENTOS

\section{CELI APARECIDA CARDOSO}

Avaliação de danos induzidos em ratos Wistar (Rattus norvergicus) expostos ao extrato aquoso de neem (Azadirachta indica) em mesmas concentrações utilizadas na lavoura de milho (Zea mays) para o controle da lagarta do cartucho (Spodoptera frugiperda).

\section{(VERSÃO CORRIGIDA)}

Tese apresentada à Faculdade de Zootecnia e Engenharia de Alimentos da Universidade de São Paulo, como parte dos requisitos para a obtenção do Título de Doutora em Ciências.

Área de Concentração: Biociência Animal

Orientadora: Prof. $\stackrel{\text { a }}{\text { Dr }} \stackrel{\text { a }}{\text {. Daniele dos }}$ Santos Martins 
Ficha catalográfica elaborada pelo

Serviço de Biblioteca e Informação, FZEA/USP,

com os dados fornecidos pelo(a) autor(a)

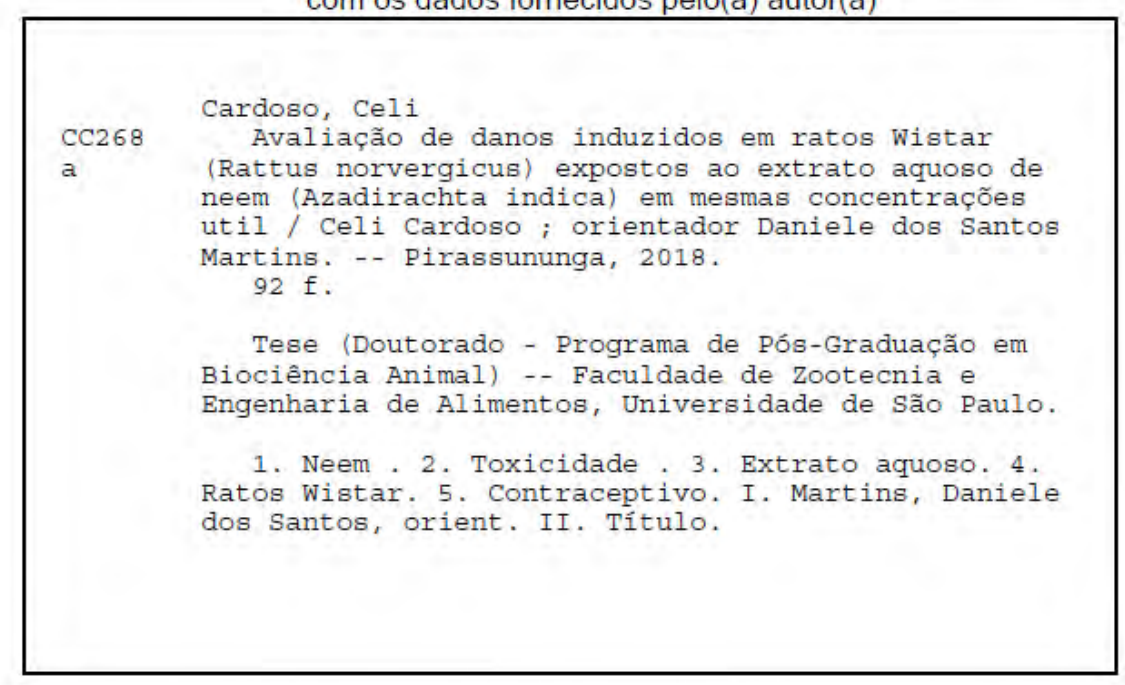

Permitida a cópia total ou parcial deste documento, desde que citada a fonte - o autor 


\section{FOLHA DE APROVAÇÃO}

Nome: Celi Aparecida Cardoso

Título: Avaliação de danos induzidos em ratos Wistar (Rattus norvergicus) expostos ao extrato aquoso de neem (Azadirachta indica) em mesmas concentrações utilizadas na lavoura de milho (Zea mays) para o controle da lagarta do cartucho (Spodoptera frugiperda).

Data da Aprovação:

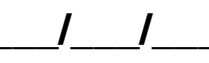

\section{BANCA EXAMINADORA}

Prof.(a)Dr.(a)

Instituição

Prof.(a) Dr.(a)

Instituição

Prof.(a) Dr.(a)

Instituição

Prof.(a) Dr.(a)

Instituição

Prof.(a) Dr.(a)

Instituição 


\section{Dedicatória}

Dedico este trabalho a minha adorada família, que me apoiou desde o primeiro instante. Sem vocês nenhuma conquista valeria a pena!

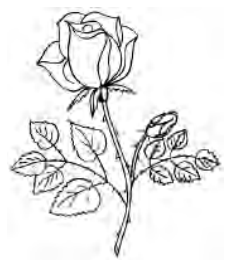

"A grandeza da vida não consiste em não cair nunca, mas em nos levantarmos cada vez que caímos". 


\section{Agradecimentos}

Primeiramente a Deus, pois sem Ele nada teria conseguido.

Á todos que de alguma forma contribuíram para que concluísse este trabalho.

Foram muitas as pessoas que estiveram ao meu lado durante essa caminhada. Talvez eu não consiga expressar toda a minha gratidão por meio de palavras...

Quero agradecer à minha orientadora, Prof. a Doutora Daniele dos Santos Martins, pela sua disponibilidade, mesmo em período de férias, e incentivo que foram fundamentais para realizar e prosseguir este estudo. Saliento o apoio incondicional prestado, a forma interessada, extraordinária e pertinente como acompanhou a realização deste trabalho. As suas críticas construtivas, as discussões e reflexões foram fundamentais ao longo de todo o percurso. Não posso esquecer a sua grande contribuição para o meu crescimento como ser humano e profissional. Serei eternamente grata por todo o apoio!

As minhas Queridas, Dani Passarelli, Lindsay Baltel, Márcia Monteiro e Flávia Munin, que além de contribuírem para a realização do trabalho me presentearam com amizade e carinho que foram fundamentais para minha caminhada neste doutorado. Além de conhecimento trouxeram luz a minha vida.

Aos igualmente queridos Sandra, China, Everson, Julia, Arina, Luciana e Renata B. Pulz que sempre se dispunham a ajudar de alguma maneira de forma amiga e carinhosa.

As queridas amigas Márcia e Gabi que sempre tinham palavra doces e quitutes deliciosos para aquecer o coração e o estômago.

As colegas de doutorado Mariana e Nayla pela colaboração.

Aos Professores Dr. Armindo Antônio Alves, Dr. Adriano Carregaro e Dr. Ricardo Strefezzi, muito obrigada! Ao Professor Dr. César Gonçalves de Lima (Césinha) pela colaboração com as análises estatísticas.

Ao Centro Pluridisciplinar de Pesquisas Químicas, Biológicas e Agrícolas (CPQBA) da Universidade de Campinas (Unicamp).

A minha amiga e colega de laboratório Camila Alampe, muito obrigada! 


\section{RESUMO}

\section{CARDOSO, C. A. Avaliação de danos induzidos em ratos Wistar expostos}

ao extrato aquoso de neem (Azadirachta indica) em mesmas concentrações utilizadas na lavoura de milho (Zea mays) para o controle da lagarta do cartucho (Spodoptera frugiperda). 2018. $92 \mathrm{f}$. Tese (Doutorado) - Faculdade de Zootecnia e Engenharia de Alimentos,

As dificuldades técnicas atuais para o manejo e controle de pragas que atacam as lavouras em nosso país, vêm incentivando a busca por métodos de controle alternativos e/ou complementares aos convencionais, destacando-se o potencial dos inseticidas botânicos. O Neem é uma planta nativa da Índia pertencente à família Meliaceae, conhecida popularmente como Nim ou Neem e tem sido usada por séculos no Oriente como: planta medicinal no tratamento de inflamações, infecções virais, hipertensão e febre, planta sombreadora, repelente, material para construção, combustível, lubrificante, adubo e mais recentemente como praguicida natural. Mesmo alavancada pela produção orgânica de alimentos, o uso de bioinseticidas ainda carece de mais pesquisas acerca de cada formulação principalmente sua ação sobre os organismos, sendo assim esta pesquisa visou avaliar os efeitos do extrato aquoso das folhas de Neem (Azadiractha indica) em ratos Wistar machos em idade reprodutiva, objetivando avaliar quais possíveis danos induzidos a exposição por oito dias ao extrato da planta pode resultar e também avaliar sua capacidade contraceptiva trazendo respostas importantes afim de se conhecer esta importante alternativa ao uso de agrotóxicos sintéticos. Para este estudo foram utilizados 20 ratos Wistar que foram divididos em 4 grupos compostos por 5 animais cada, sendo: G1 - 10.000ppm, G2 - 7.500ppm, G3 - 5.000 ppm e G4 - controle com água destilada. $O$ volume administrado foi padronizado em $1 \mathrm{ml}$ para cada animal e a administração deu-se por gavagem, por oito dias. Para se estudar as reações ocasionadas pelo tratamento realizamos nos animais após a administração das diferentes doses do composto o reconhecimento de sinais clínicos de toxicidade, a investigação das alterações fisiológicas, análise da qualidade do sêmen e avaliação macro e microscópicas dos órgãos alvo fígado, rins e testículos. Nossos resultados apontam que o extrato aquoso de Neem administrado por oito dias, via oral, nas doses empregadas apresentou baixa toxicidade, uma vez que não foi revelada nenhuma alteração nos quesitos avaliados, contudo apresentou resultados que levam a considerar sua capacidade contraceptiva, por terem alterando de forma negativa a motilidade e viabilidade espermática nas maiores doses administradas.

Palavras-Chave: bioinseticida, espermatogênese, histologia, motilidade. 


\begin{abstract}
CARDOSO, C. A. Evaluation of induced damages in Wistar rats exposed to neem (Azadirachta indica) aqueous extract at the same concentrations used in corn (Zea mays) plantation for control fall armyworm (Spodoptera frugiperda). 2018. $92 \mathrm{f}$. Tese (Doutorado) - Faculdade de Zootecnia e Engenharia de Alimentos, Universidade de São Paulo, Pirassununga, 2018.
\end{abstract}

The current technical difficulties for the management and control of pests that attack the crops in our country have been encouraging the search for alternative and / or complementary control methods to conventional ones, highlighting the potential of the botanical insecticides. Neem is a plant native to India belonging to the family Meliaceae, popularly known as Nim or Neem and has been used for centuries in the East as: medicinal plant (in the treatment of inflammation, viral infections, hypertension and fever), shading plant, repellent, building material, fuel, lubricant, fertilizer and more recently as natural pesticide. Even though the use of bio-insecticides is still underpinned by organic food production, there is still a need for more research on each formulation, especially its action on organisms. This research aimed to evaluate the effects of the aqueous extract of Neem leaves (Azadiractha indica) on Wistar rats males of reproductive age, aiming to evaluate which possible induced damages the exposure for eight days to the extract of the plant can result and also to evaluate its contraceptive capacity bringing important answers in order to know this important alternative to the use of synthetic agrochemicals. For this study 20 Wistar rats were divided into 4 groups composed of 5 animals each, being: G1 - 10.000ppm, G2 - 7,500ppm, G3 $-5,000 \mathrm{ppm}$ and G4 - control with distilled water. The volume administered was standardized in $1 \mathrm{ml}$ for each animal and administration was given by gavage for eight days. In order to study the reactions caused by the treatment, the clinical signs of toxicity were confirmed in the animals after administration of the different doses of the compound, investigation of physiological changes after administration of the extract, analysis of the semen quality and macro and microscopic evaluation of the organs target liver, kidneys and testicles. After analysis of the results obtained it can be considered that the aqueous extract of Neem administered for eight days, orally, in the doses used presented low toxicity, since no changes were revealed in the evaluated items, however presented results that lead to consider its contraceptive capacity, because it has negatively altered motility and sperm viability at the highest doses administered.

Keywords: bio-insecticide, spermatogenesis, histology, motility. 


\section{LISTA DE FIGURAS}

Figura 1- Esquema demonstrando a natureza clonal das células germinativas 25

Figura 2: Feixe de microtúbulos e proteínas associadas que formam o cerne de cílios e flagelos em uma célula eucariótica, responsável pelos seus movimentos

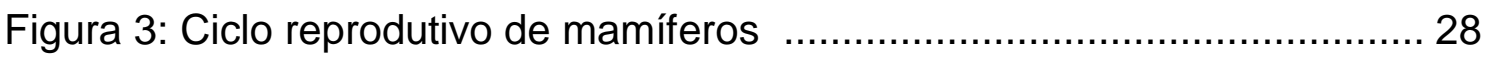

Figura 4: Fluxograma experimental do projeto ………................................. 50

Figura 5: Método de seleção de campos para avaliação da motilidade ...........54

Figura 6: Fotomicrografias de espermatozoides ratos Wistar expostos a diferentes concentrações de extrato aquoso de nem ..................................... 63

Figura 7 - Histologia dos órgãos alvo: testículo, fígados e rim de ratos Wistar expostos a diferentes concentrações de extrato aquoso de neem 68 


\section{LISTA DE TABELAS}

Tabela 1 - Médias de peso, consumo de ração e água e temperatura retal dos ratos Wistar expostos a diferentes concentrações de extrato aquoso de neem

Tabela 2: Porcentagens relacionada a motilidade dos espermatozoides em cada um dos grupos avaliados 62 Tabela 3: Porcentagens relacionada a viabilidade dos espermatozoides em cada um dos grupos avaliados 63 Tabela 4 - Parâmetros Hematológicos dos ratos Wistar expostos a diferentes concentrações de extrato aquoso de neem 65

Tabela 5: - Valores de massa úmida dos órgãos alvo de ratos Wistar expostos a diferentes concentrações de extrato aquoso de neem 66 


\section{SUMÁRIO}

1. INTRODUÇÃO

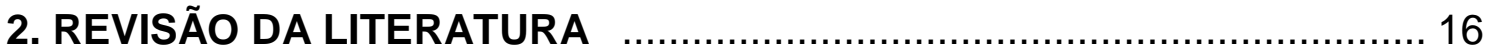

2.1 A questão do uso de agrotóxicos no Brasil .......................................... 16

2.2 Inseticidas Sintéticos X Inseticidas Naturais e as implicações e usos na produção de alimentos afim de combater a escassez..................................... 17

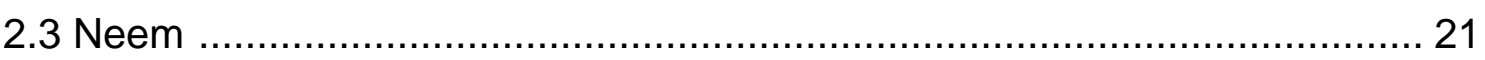

2.4 Testículos, a Espermatogênese e possíveis alterações no processo

2.5 Alterações reprodutivas induzidas por Azadiractha indica

2.6 Parâmetros hematológicos de Ratos Wistar

2.7 Alterações fisiológicas em mamíferos ocasionadas por espécies vegetais..

2.8 Parâmetros Histológicos normais de Fígado e Rins e alterações induzidas por plantas

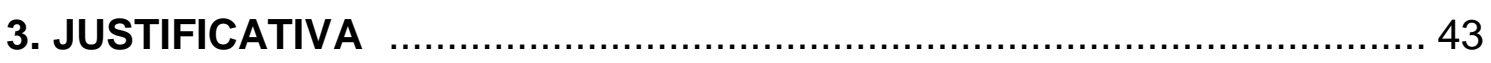

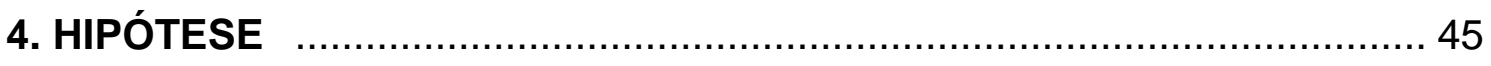

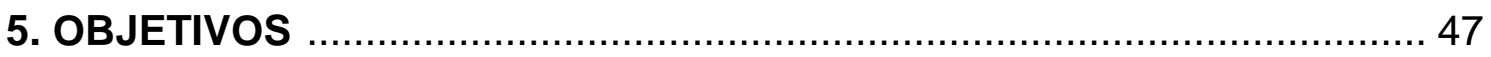

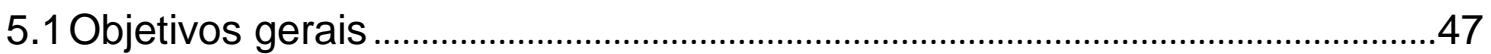

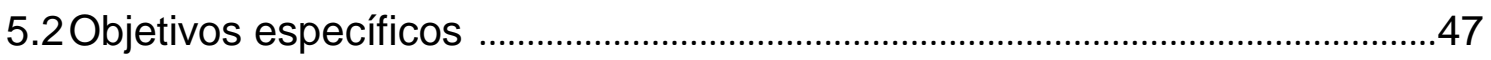

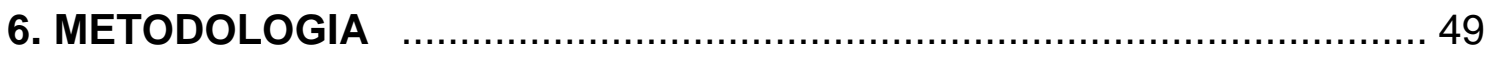

6.1 Coleta das folhas, obtenção do extrato aquoso de Azadirachta indica e

Tratamento dos animais com extrato aquoso............................................... 51

6.2 Alterações Fisiológicas gerais ...............................................................................52

6.2.1 Verificação de peso, consumo de ração e água, temperatura retal gerais

6.2.2 Avaliação de sinais clínicos de toxicidade .......................................................52

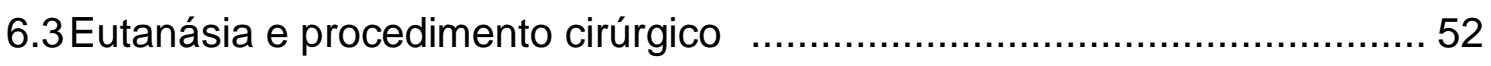

6.4 Análise da qualidade do sêmen ..........................................................................53

6.4.1 Avaliação macroscópica do sêmen ................................................................53

6.4.2 Motilidade dos espermatozoides ……………………………………………....54 
6.4.2.1 Avaliação da viabilidade do sêmen .............................................................55

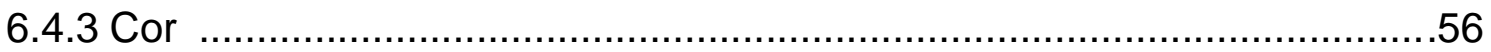

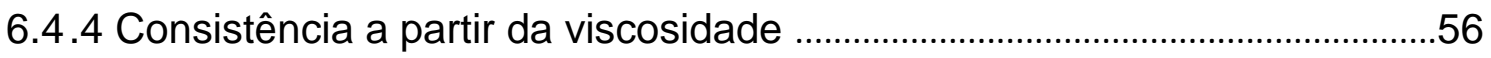

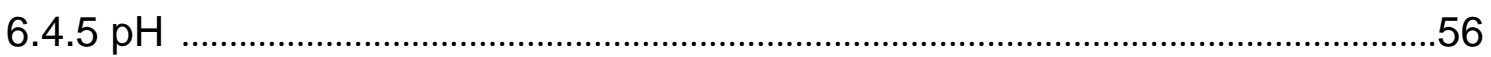

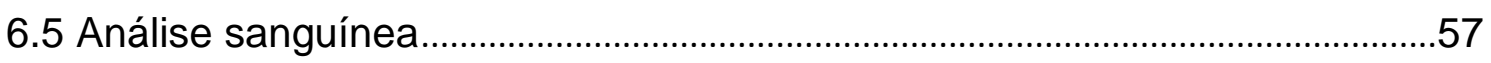

6.6 Avaliação macro e microscópica dos órgãos alvo ..............................................57

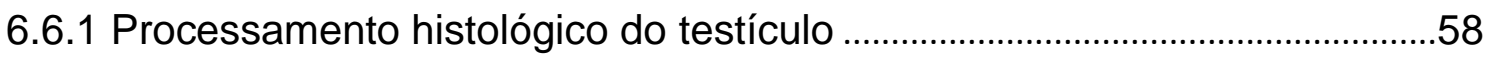

6.6.2 Processamento histológico do fígado e rins .......................................................58

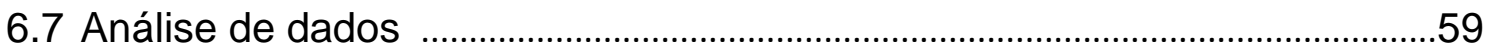

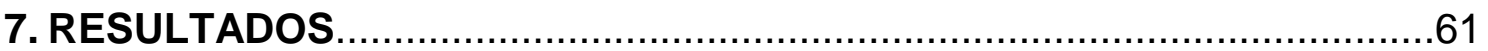

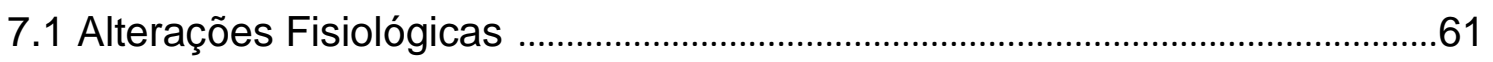

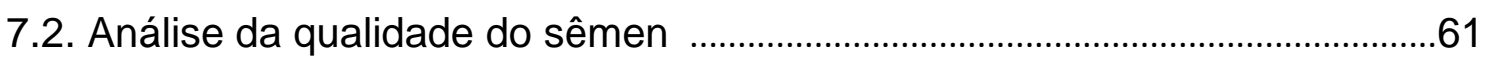

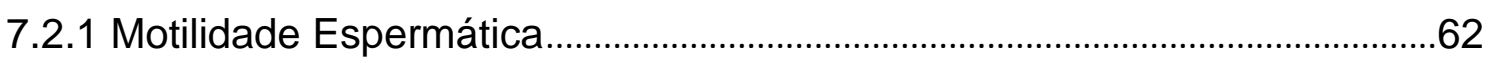

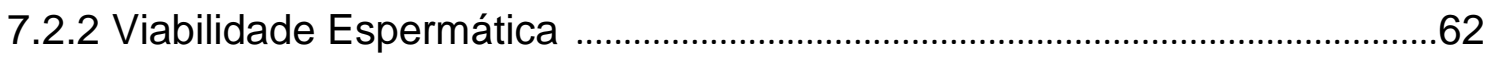

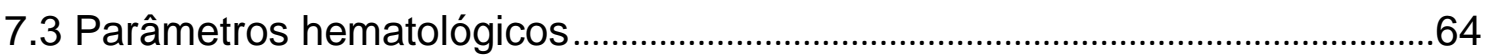

7.4 Avaliações macro e microscópica dos órgãos alvo: Testículo, Fígado e Rins.. .66

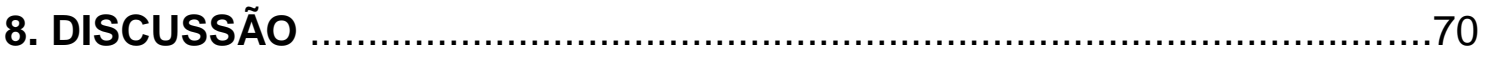

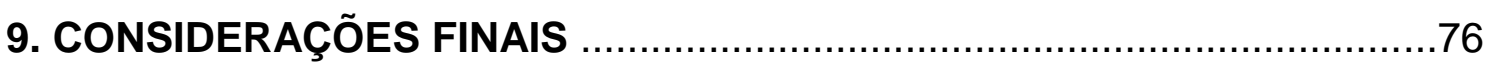

10.SUGESTÕES PARA TRABALHOS FUTUROS ................................78

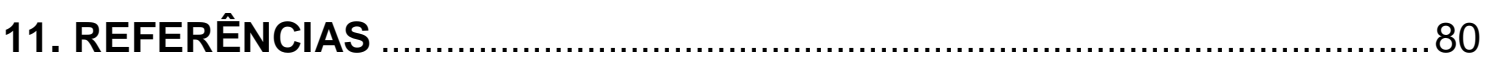


1. INTRODUÇÃO

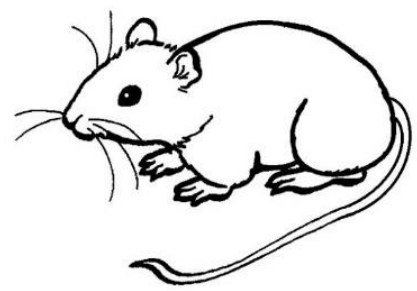




\section{INTRODUÇÃO}

As dificuldades técnicas atuais para o manejo e controle de pragas que atacam as lavouras em nosso país, vêm incentivando a busca por métodos de controle alternativos e/ou complementares aos pesticidas convencionais, destacando-se o potencial dos inseticidas botânicos (BÉLO, et al., 2009).

Bioinseticidas originados de plantas, por serem ricos em moléculas bioativas, podem ser utilizados como uma forma alternativa aos agrotóxicos sintéticos no controle de pragas na atividade agrícola. Possuem também a capacidade de biodegradação, importante característica, uma vez que os inseticidas químicos deixam resíduos originando problemas ambientais (BEZERRA, CARNEIRO e MARCIANO DE PAULA, 2015). Mesmo alavancada pela produção orgânica de alimentos, o uso de bioinseticidas ainda carece de mais pesquisas acerca de cada formulação e sua possibilidade de deposição de resíduos e ação sobre os organismos (MORANDI FILHO, et al., 2006. )

Um exemplo de uma importante lavoura que requer uso de inseticida para garantir produção em nosso país é a de milho, importante no aspecto social sendo fonte alimentar entre a camada mais pobre da população e econômico com uma produção de 14,0 milhões de hectares (MELO FILHO e ALCEU RICHETTI, 1990; GARCIA, et al., 2004).

Um dos grandes incentivos à pesquisa por novos inseticidas naturais tem sido a percepção de que os produtos naturais podem, na maioria das vezes, trazer grandes vantagens em relação aos inseticidas sintéticos, como em relação ao custo e no que se refere a danos ao meio ambiente e saúde humana e animal por serem, muitas vezes, biodegradáveis (BÉLO, et al., 2009).

A espécie Azadirachta indica da família Meliaceae popularmente denominada Neem no Brasil, espécie esta originária da Índia e adaptada no Brasil tem sido muito estudada quanto às suas propriedades terapêuticas e, quanto ao seu potencial como inseticida natural, seus extratos vem apresentando tão potentes propriedades inseticida quanto os inseticidas comerciais (PRATES, VIANA e WAQUIL, 2003; MOURÃO, et al., 2004). A planta Neem tem como um dos principais metabólitos secundário a azadirachitina, que pode ser obtido através de processos relativamente simples, como a destilação 
com vapor ou extração com solventes aquosos ou orgânicos (SOUZA CHAGAS, 2004).

Os metabólitos secundários produzidos pelas plantas representam uma interface química entre os vegetais e o ambiente circundante, portanto, sua síntese é frequentemente afetada por condições ambientais. A época em que uma planta é coletada, a idade do vegetal, o desenvolvimento, a temperatura, a disponibilidade hídrica e radiação ultravioleta no local, nutrientes, altitude, poluição atmosférica, indução por estímulos mecânicos ou ataque de patógenos, são fatores importantes, uma vez que a quantidade e, às vezes, até mesmo a natureza dos princípios ativos não é constante durante o ano (GOBBO-NETO e LOPES, 2007).

Mimetizar a toxicidade e possível atividade terapêutica do extrato aquoso de uma planta adaptada no Brasil em organismo de mamífero em mesmas concentrações e no mesmo tempo indicados para uso em lavouras de milho se faz de suma necessidade uma vez que seu uso está sendo indicado para lavouras em todo o país.

A definição da concentração do extrato aquoso empregada neste presente estudo foi baseada no trabalho desenvolvido pela Embrapa Milho e Sorgo acerca das doses que se mostraram eficazes para uso na lavoura de milho para controle da lagarta do cartucho publicados por Viana e Aquino Ribeiro (2010). A fixação do tempo de tratamento foi baseada em circular técnica 88 publicada pela Embrapa, onde a eficiência da aplicação do extrato foliar de Neem (Azadirachta indica) demonstrou maior eficácia até o oitavo dia após o início do tratamento no controle da lagarta do milho (S. frugiperda) (VIANA, PRATES e RIBEIRO, 2006). 
2. REVISÃO DE LITERATURA

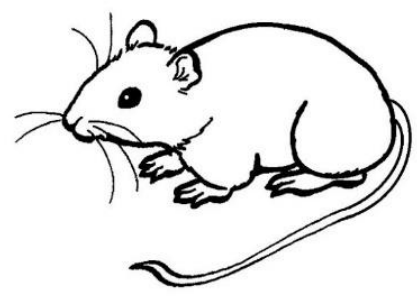




\section{REVISÃO DA LITERATURA}

\subsection{A questão do uso de agrotóxicos no Brasil}

Desde a década de 70 pode ser observado no Brasil uma queda significativa da população que habita e trabalha em áreas rurais, no estado de São Paulo, por exemplo, pode-se notar que desde os anos 1970 a 1996, 90\% da população residiam nas áreas urbanas. A situação da população das áreas rurais também estimularam esse êxodo exacerbado, não é incomum ainda encontrar locais como esse sem saneamento básico, transporte público, água potável, etc. (MOREIRA, et al., 2002).

Tal situação mais o desprezo por parte dos governos fizeram com que um número cada vez maior de produtores rurais, na maioria das vezes despreparados e mal orientados fizesse uso de agrotóxicos para garantir uma produtividade cada vez mais elevada. Levantamentos do final da década de 90 apontaram para o uso de 2,5 á 3 milhões de toneladas por ano de agrotóxicos nas lavouras em todo o mundo, sendo o Brasil responsável pelo uso de $50 \%$ do consumo de toda a América Latina. Dados mais recentes apontam para o uso de mais 1 milhão de toneladas de agrotóxicos ao ano no país, o que equivale a um consumo médio de 5,2 $\mathrm{kg}$ de veneno agrícola por habitante (MOREIRA, et al., 2002 e BRASIL, 2005).

Os dados de intoxicação humana e de contaminação ambiental provocadas pelo uso generalizado de agrotóxicos são alarmantes, o emprego massivo de agrotóxicos por conta da expansão do agronegócio está contaminando os alimentos, as águas e $o$ ar. Pesquisas recentes encontraram resíduos de agrotóxicos em amostras de água da chuva em escolas públicas no Estado de Mato Grosso, e também no sangue e urina de moradores locais (LONDRES, 2011). A intoxicação aguda por agrotóxicos é a mais comum e causa danos, principalmente, em indivíduos expostos no ambiente de trabalho (exposição ocupacional) (BRASIL, 2005).

A intoxicação crônica, por sua vez, pode afetar toda uma população, uma vez que ocorre em razão da exposição múltipla aos agrotóxicos, ou seja, da presença de resíduos de agrotóxicos no ambiente e em alimentos, geralmente em doses baixas. Dentre os efeitos associados à exposição crônica a ingredientes ativos de agrotóxicos podem ser citados infertilidade, impotência, 
abortos, malformações, neurotoxicidade, desregulação hormonal, efeitos sobre o sistema imunológico, câncer, doença do fígado e dos rins, doenças respiratórias, efeitos no desenvolvimento da criança, entre outros. Efeitos adversos decorrentes da exposição crônica aos agrotóxicos podem aparecer muito tempo após a exposição, dificultando assim a correlação com o agente tóxico (LONDRES, 2011; INCA, 2015).

No Estado do Ceará uma pesquisa realizada entre agricultores que trabalhavam com agrotóxicos demonstrou que este grupo apresentou maior risco de ter câncer de pênis (6,44\% mais chances de desenvolver a doença), leucemias $(6,35 \%$ mais chances), testículo $(5,77 \%)$, bexiga urinária $(1,88 \%)$, mieloma múltiplo $(1,83 \%)$, mama masculina $(1,6 \% 7)$, linfomas $(1,63 \%)$, tecido conjuntivo (1,62\%), olhos e anexos (1,58\%), esôfago (1,40\%), cólon - junção reto sigmóide $(1,31 \%)$, rim $(1,30 \%)$, laringe $(1,30 \%)$, próstata $(1,17 \%)$ e tireoide $(1,12 \%)$; vale ressaltar que não somente os aplicadores correm tal risco, mas ainda as mulheres que lavam as roupas e as crianças que brincam por entre as lavouras (LONDRES, 2011).

\subsection{Inseticidas Sintéticos X Inseticidas Naturais e as implicações e usos na produção de alimentos afim de combater a escassez}

A grande maioria dos países reconhecem a necessidade do desenvolvimento sustentável, e de práticas denominadas verdes, que tenham por resultado menos resíduos e evitem desperdício. Principalmente Europa e Japão, visam a produção de produtos de maneira menos agressiva para o meio ambiente (GUARATINI, et al., 2008). Uma saída em franca expansão para tal situação é a utilização de bioinseticidas. Alternativas para o controle de pragas na produção orgânica dizem respeito ao uso de plantas inseticidas, com destaque para o neem (Azadirachta indica), o piretro natural extraído das flores do Chrysanthemum cinerariaefolium, além do emprego da bactéria Bacillus thuringiensis (MORANDINI FILHO, et al., 2006).

Os inseticidas naturais normalmente não apresentam problemas de contaminação ambiental, resíduos tóxicos nos alimentos, efeitos prejudiciais a organismos benéficos e seleção de insetos resistentes, contudo autores têm demonstrado uma resposta diferenciada dos inimigos naturais em função da 
aplicação de tais inseticidas, levando à necessidade de se gerar informações específicas para cada formulação, inimigo natural e sistema de produção (MORANDINI FILHO, et al., 2006).

Estudo comparando a qualidade de sêmen entre 171 agricultores convencionais expostos aos agrotóxicos e 85 que trabalham com a produção orgânica, foi observado que houve uma porcentagem estatisticamente significativa para o número de espermatozoides mortos para aqueles mais expostos aos agrotóxicos. Entretanto, para parâmetros como concentração de espermatozoides, morfologia e motilidade foram encontradas diferenças apenas secundárias ou estatisticamente não significativas (DAROLT, 2003).

Em pesquisas realizadas com cultura rasteira que dependendo da fase da cultura há uma variação de 14 a $73 \%$ do agrotóxico que é perdido para o solo e como consequência de tal fato, pode-se ter também a contaminação da água pois, uma vez que o solo esteja contaminado pode ser levado pela água das chuvas para rios, lagos. O contaminante presente no solo pode chegar até mesmo a fonte subterrânea de água através das áreas de recarga pelas águas superficiais e também pela lixiviação. Foi detectada por exemplo, a presença de traços de dois agrotóxicos usados comumente na cana-de-açúcar no Aquífero Guarani no município de Ribeirão Preto e Rio Pardo no interior do estado de São Paulo (MATA e FERREIRA, 2013).

No Programa de análise de resíduos de agrotóxicos em alimentos (PARA) relatório de atividades de 2013 a 2015 da ANVISA (Agência Nacional de Vigilância Sanitária), foi detectado 2.371 amostras insatisfatórias, 452 delas apresentaram como único motivo de irregularidade a presença de resíduos de agrotóxicos não autorizados para a cultura em concentrações inferiores a 0,01 $\mathrm{mg} / \mathrm{kg}$, o que representa $19,1 \%$ do número de amostras insatisfatórias e 3,75\% do número total de amostras analisadas.

Quando uma planta recebe a aplicação de um produto forma-se uma camada que recobre as folhas, frutos ou raízes e tal camada, deve ser considerada apenas como um depósito de material. Essa camada deve sofrer a ação dos fatores do clima como, chuva, vento, etc., e apenas o que é absorvido em maior ou menor quantidade nas plantas deve ser verdadeiramente considerado como resíduo, podendo variar de acordo com a característica química do produto utilizado (GIANNOTTI, 1983). 
A intoxicação aguda por exposição a resíduos de agrotóxicos na dieta é bem documentada, como exemplo, tem-se os casos de intoxicação ocorridos nos Estados Unidos na década de 80, pelo consumo de pepino e melancia contendo aldicarbe, e na Irlanda, no início dos anos 90 , pelo consumo de pepino cultivado hidroponicamente, também devido à presença de aldicarbe. Nos dois casos, as intoxicações foram decorrentes de aplicação indevida do produto nessas culturas (ANVISA, 2016).

Muitos sintomas clínicos decorrentes da intoxicação aguda por determinados agrotóxicos são similares aos oriundos de intoxicação alimentar de caráter microbiológico. Nesse caso, os sintomas podem ser facilmente confundidos pelos indivíduos, atribuindo o efeito ao fato de o alimento poder estar deteriorado $e$, consequentemente, resultando em um quadro de subnotificação desses eventos (ANVISA, 2016).

A partir de tais fatos, verificou-se que inúmeros agrotóxicos apresentam toxicidade aguda que podem representar risco dietético, e o parâmetro DRfA (Dose de referência aguda) passou a fazer parte da rotina regulatória no processo de autorização do uso de agrotóxicos em culturas agrícolas em vários países e na União Europeia (ANVISA, 2016).

$\mathrm{Na}$ agricultura brasileira um dos maiores desafios é desenvolver sistemas agrícolas sustentáveis, que possam produzir alimentos em quantidade e qualidade suficientes para alimentar toda a população. No sentido de reduzir os problemas enfrentados com os inseticidas químicos, o uso de produtos naturais extraídos de plantas apresenta-se como uma alternativa viável devido a sua baixa toxicidade e eficiência contra várias espécies de insetos-praga (SILVA, et al., 2009; MACIEL, et al., 2010).

Vale ressaltar que no mesmo intuito de buscar soluções para a escassez de alimentos que pode também ser impulsionada pela expansão demográfica desordenada, são utilizados muitos métodos contraceptivos, em sua grande maioria de uso feminino. Contudo a Organização Mundial de Saúde (OMS) vem incentivando as pesquisas com espécies vegetais com potencialidade contraceptiva masculina (SOUSA, et al., 2013).

Uma lacuna importante que deve ser preenchida pela pesquisa é a análise de resíduos de produtos naturais, permitidos pela agricultura orgânica. Esses produtos naturais (inseticidas e fungicidas biológicos a base de rotenona, 
piretro, enxofre e cobre, por exemplo) utilizados para o combate de pragas e doenças, tendem a se degradar rapidamente no meio ambiente, porém devem ser usados em ocasiões especiais com a supervisão das certificadoras. Mesmo não havendo nenhuma evidência objetiva que estes resíduos ofereçam perigo de contaminação aos consumidores, é preciso que estes elementos também sejam avaliados em testes de resíduos (DAROLT, 2003).

O Neem (Azadirachta indica) é uma árvore milenar, nativa da Índia, que vem sendo utilizada há séculos para os mais variados fins dentre eles: planta medicinal no tratamento de inflamações, infecções virais, hipertensão e febre, planta sombreadora, repelente, material para construção, combustível, lubrificante, adubo e mais recentemente como praguicida natural. A planta fornece grande número de metabólitos secundários com atividade biológica, sendo a azadiractina considerada de maior importância ecológica (MOSSINI e KEMMELMEIER, 2005).

Apesar dos compostos bioativos presentes no Neem serem encontrados em toda a planta, aqueles presentes primeiramente nas sementes e folhas são os que possuem compostos mais concentrados e acessíveis, facilmente obtidos por meio de processos de extração em água e solventes orgânicos como hidrocarbonetos, alcoóis, cetonas ou éteres, assim sendo suas atividades medicinais e praguicidas têm sido fonte de grande interesse na pesquisa científica (MOSSINI e KEMMELMEIER, 2005).

Entretanto a grande maioria dos trabalhos publicados tem como base de estudo o óleo ou o pó obtido das sementes do Neem (Azadirachta indica), também conhecido como lilás indiano, muito embora exista nas sementes maior quantidade de princípios ativos quando comparado as demais partes da planta, em uma região onde o vegetal por condições edafoclimáticas possa produzir poucas sementes, seu uso seria significativamente limitado (VIANA e AQUINO RIBEIRO, 2010; CHAUDHARY, et al., 2017).

Deve-se considerar também que a extração do óleo das sementes seria inviável em pequenas quantidades uma vez que requer tecnologia especifica e equipamentos onerosos para tal, este fato inviabilizaria seu uso tanto na lavoura, quanto para finalidades terapêuticas, uma vez que uso medicinal também é relatado principalmente por populações de seu local de origem (SUBAPRIYA e NAGINI, 2005; VIANA e AQUINO RIBEIRO, 2010). 


\subsection{Neem}

Planta cujo nome cientifico é Azadirachta indica, nativa da Índia pertencente à família Meliaceae, como o mogno da Amazônia, o cedro, a Melia Azedarach (santa-bárbara ou cinamomo). O Neem é característico de clima tropical, seu florescimento é dos meses de fevereiro a maio sendo que seus frutos amadurecem de junho a agosto em área de ocorrência natural. Trata-se de uma planta que propaga com facilidade, tanto sexualmente quanto vegetativamente, podendo ser plantado por meio de sementes, mudas, árvores novas, brotos de raiz ou tecido de cultura. No entanto, seu crescimento se mostra melhor em áreas com chuvas anuais de 800 - $1800 \mathrm{~mm}$, solos arenosos, profundos e bem drenados, com pH entre 6,5 e 7,5 e temperaturas de $20{ }^{\circ} \mathrm{C}$ (MOSSINI e KEMMELMEIER, 2005; BARROS BRASIL, 2013).

As folhas especificamente apresentam usos medicinais como: Antifúngico, Agente Anticoagulante, Anti-helmíntico, Antituberculosa, Antitumoral, Antisséptico, Antiviral, contraceptivo, Cosméticos, Fertilizantes, Inseticidas, Nematicidas, Repelentes de Insetos, Dor de ouvido, Icterícia, Queimaduras, Diabetes, Catapora, Varíola, Verruga, Caspa, Tumores gandulares (BARROS BRASIL, 2013).

Assim como outras meliaceaes, possuem compostos limonóides como a azadiractina, salanina, melantriol e nimbina, contudo muitos compostos ativos pode ser extraídos das diferentes partes da árvore do Neem incluindo tetraterpenóides, carotenoides, compostos fenólicos, cetonas e esteroides. Tais compostos apresentam baixa toxicidade aos vertebrados, dentre os mais de 40 terpenóides já identificados na planta que possuem ação contra insetos, a azadiractina é o composto mais eficiente. A azadiractina é uma molécula muito extensa e ainda não pode ser sintetizada, sendo assim todos os produtos que a contém são produzidos por extração da planta (SILVA, 2010).

A azadiractina se encontra nas folhas, frutos e sementes do Neem, em seu óleo foram isoladas substâncias como Nemola $\left(\mathrm{C}_{15} \mathrm{H}_{30} \mathrm{O}_{3} \mathrm{~S}\right)$, Margosin $\left(\mathrm{C}_{28} \mathrm{H}_{48} \mathrm{O}_{10}\right)$, glicosídeo, ácido palmítico, ácido tetradecóico e um ácido denominado D do Neem, Nimbim, Nimbinim, e Nimbidim. Das flores do Neem $\mathrm{Na}, \mathrm{K}, \mathrm{Ca}, \mathrm{Cl}, \mathrm{CO}_{2}, \mathrm{SO}_{4}$ e $\mathrm{SiO}_{2}$, além do Nimbosterol $\left(\mathrm{C}_{20} \mathrm{H}_{34} \mathrm{O}\right)$, glicosideo 
Nimbosterim, flavonóide, Nimbicetim $\left(\mathrm{C}_{15} \mathrm{H}_{6} \mathrm{O}_{2}(\mathrm{OH})\right)$ e sesquiterpenos (BARROS BRASIL, 2013).

Produtos à base de óleo de Neem têm demonstrado efeitos antifertilidade, ação espermicida direta e atividade antimicrobiana significativa contra patógenos sexualmente transmissíveis. O efeito contraceptivo pós-coital do óleo de Neem não envolve estrogênio ou progesterona, podendo ser considerado como efeito não-hormonal, portanto, não ocasionando os efeitos colaterais dos contraceptivos esteroides. Em adição à ação contraceptiva, têm sido descritas ações antimicrobianas associadas (antibacteriana, antifúngica e antiviral), úteis na prevenção contra doenças (MOSSINI e KEMMELMEIER, 2005).

Sementes e folhas administradas oralmente possuem imunomoduladores que induzem reações imunocelulares, causando interrupção completa da gestação antes do estágio de implantação em roedores e primatas, de forma reversível, sendo a fertilidade restaurada nos ciclos subseqüentes. As folhas de Neem podem atuar como mediador na ativação da resposta imune, pesquisas em ratos revelaram o efeito profilático e terapêutico das folhas sobre carcinoma de Ehrlich e melanoma B16, e foi verificado também que o extrato é capaz de proteger o animal contra o crescimento do tumor e assim atuar como agente quimiopreventivo, mediante a ativação imune e/ou outros mecanismos de defesa do hospedeiro (MOSSINI e KEMMELMEIER, 2005).

Os efeitos imunomoduladores têm recebido grande atenção, devido às suas propriedades diuréticas, antimicrobianas, antiinflamatórias, antipiréticas, antitumorais, ativação de linfócitos T e indutoras de interferon (MUKHERJEE, GARG e TALWAR, 1999; MOSSINI e KEMMELMEIER, 2005).

\subsection{Testículos, a Espermatogênese e possíveis alterações no processo}

O aparelho reprodutor masculino é composto dos testículos; que tem como funções a produção de hormônios e espermatozoides, ductos genitais, glândulas seminais, próstata, glândulas bulbouretrais e pênis. Cada testículo é envolto por uma grossa cápsula de tecido conjuntivo denso chamado túnica albugínea; é formado por lóbulos que se intercomunicam e cada lóbulo é ocupado por um a quatro túbulos seminíferos que se alojam como novelos dentro 
de um tecido conjuntivo frouxo rico em vasos sanguíneos e linfáticos, nervos e células de Leydig (JUNQUEIRA e CARNEIRO, 2004; GOMES, 2007).

Os túbulos seminíferos são constituídos por túnica própria, epitélio seminífero e lumen tubular. A túnica própria reveste o túbulo externamente, sendo composta de células mióides e membrana basal (CHIEREGATTO, 2005). O epitélio seminífero, reveste a superfície interna dos túbulos seminíferos, sendo formado por dois tipos celulares distintos: as células da linhagem germinativa e as de Sertoli, de linhagem somática, responsáveis pela sustentação e nutrição das células germinativas. No compartimento tubular, as células germinativas estão dispostas de forma concêntrica, o que faz com que as células imaturas fiquem próximas da membrana basal em outro compartimento: o basal, e as mais maduras, no adluminal que termina no lúmen do túbulo seminífero (PANNOCCHIA, 2008).

As células espermatogênicas se encontram arranjadas nos túbulos seminíferos de forma organizada, formando associações celulares que caracterizam os estádios do ciclo do epitélio seminífero que pode ser definido como o período do desaparecimento de um determinado estádio até o seu reaparecimento neste mesmo segmento. A duração do ciclo do epitélio seminífero é geralmente constante para uma determinada espécie, variando, no entanto, de uma espécie para a outra. Este intervalo de tempo dura 13,5 dias no touro; 13,6 dias no cão; 12,9 dias no rato; 8,9 dias no camundongo (COSTA e REGO DE PAULA, 2003).

Nos túbulos seminíferos, as células germinativas não estão organizadas ao acaso, mas sim em organizações celulares distintas denominadas estádios que se sucedem com o tempo, de maneira bem ordenada formando o ciclo do epitélio seminífero (CHIEREGATTO, 2005).

Existe grande variação no número e nas dimensões dos túbulos seminíferos nas diferentes espécies de mamíferos, o comprimento total dos túbulos está relacionado a três parâmetros estruturais, sendo eles: tamanho do testículo, diâmetro tubular e densidade volumétrica dos túbulos. O camundongo possui aproximadamente 20 túbulos seminíferos por testículo, perfazendo no total cerca de 2 metros de comprimento tubular por gônada (GOMES, 2007).

A espermatogênese é um processo cíclico altamente organizado e complexo que ocorre nos túbulos seminíferos e passa por três fases essenciais: 
a primeira, a proliferativa, em que as células sofrem sucessivas e rápidas divisões mitóticas; a segunda, a meiótica ou espermatocitária, na qual o material genético dos espermatócitos é duplicado, recombinado e segregado; por fim, a espermiogênica, em que células haplóides (espermátides) se diferenciam em espermatozoides - célula altamente especializada e estruturalmente equipada para alcançar e fertilizar o oócito ( BACHA JR. e BACHA, 2003; PANNOCCHIA, 2008) .

O processo de formação dos espermatozoides pode também ser estudado em duas etapas: Espermatogênese e Espermiogênese. $\mathrm{Na}$ espermatogênese o processo tem início através de uma célula germinativa primitiva, a espermatogônia, sendo uma célula relativamente pequena que se divide por mitose originando: Espermatogônias de tipo A que se diferenciam durante sucessivos ciclos de divisão até se tornarem Espermatogônias de tipo $B$ as células progenitoras que irão se diferenciar em Espermatócitos primários que apresentam 46 cromossomos e logo após sua formação entram em prófase da primeira divisão meiótica; como esta fase dura cerca de 22 dias, a maioria dos espermatócitos vistos nos cortes histológicos estará nessa fase (JUNQUEIRA e CARNEIRO, 2004 ; MURTA , GOMES e MARTINEZ, 2013 ).

Da primeira divisão meiótica citada acima surgem duas células menores que são os Espermatócitos secundários, que apresentam somente 23 cromossomos, estas células permanecem um tempo bem curto em interfase e logo entra na segunda divisão meiótica, que também é rápida. A divisão de cada espermatócito secundário resulta em duas células, as espermátides como pode ser visualizado na Figura 1 a seguir (JUNQUEIRA e CARNEIRO, 2004). 
Figura 1- Esquema demonstrando a natureza clonal das células germinativas

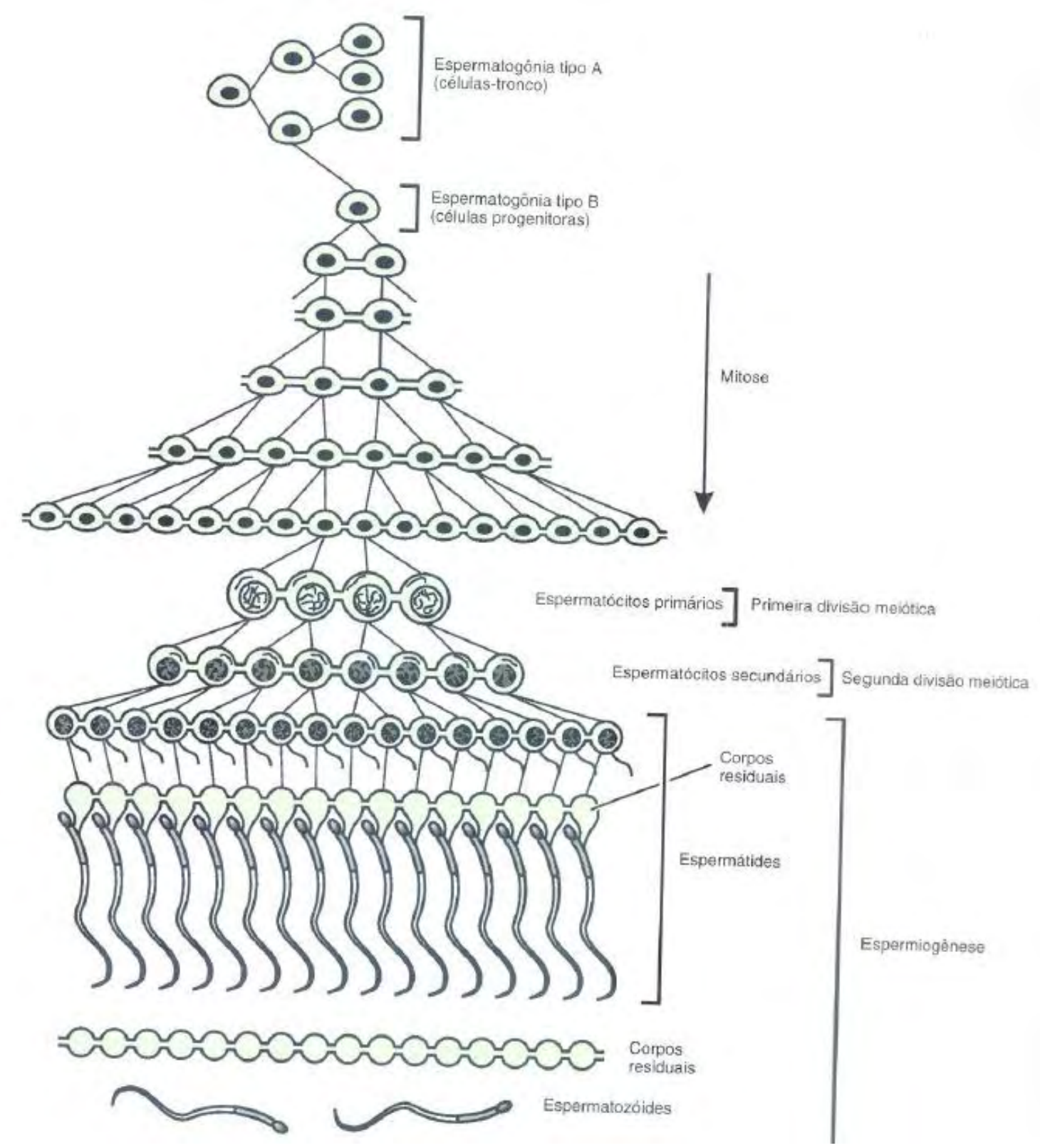

Fonte: (Junqueira e Carneiro, 2004).

Legenda: No início do processo, somente as espermatogônias tipo A se dividem, produzindo células - filhas que continuam a se dividir. Algumas de suas células-filhas comprometidas com a diferenciação em espermatogônias tipo B se se separam nas divisões sucessivas, permanecendo presas por pontes citoplasmáticas. Essas células voltam a ser individualizadas após a perda dos corpos residuais e a maturação completa dos espermatozoides.

$\mathrm{Na}$ Espermiogênese ocorre a transformação das espermátides em espermatozoides, abrangendo um processo complexo que inclui a formação do acrossomo, condensação e alongamento do núcleo, desenvolvimento do flagelo 
e a perda de parte do citoplasma. Durante a etapa do acrossomo, acontece também a formação do flagelo; as mitocôndrias vão se acumulando ao redor da porção proximal do flagelo por se tratar de local de movimento celular e alto consumo de energia onde são gerados o movimento flagelar do espermatozoide. O movimento flagelar é resultado da interação entre microtúbulos, ATP e dineína, proteína com atividade de ATPase (JUNQUEIRA e CARNEIRO, 2004).

Nas células germinativas, os microtúbulos são responsáveis pela separação dos cromossomas durante a mitose e a meiose, bem como pela migração do espermatozoide e núcleo do ovo durante a fertilização. Considerase que um ou mais defeitos dos microtúbulos podem ser prejudiciais ao movimento ciliar e/ou às divisões mitótica ou meiótica, prejudicando assim a fertilização (OLIVEIRA, et al., 2006).

No flagelo de cada espermatozoide normalmente se forma um círculo de microtúbulos, composto por 9 pares periféricos fundidos e 2 simples centrais independentes, onde cada par é constituído por um microtúbulo mais interno e outro mais externo. Os pares estão unidos por pontes de nexina e ligam-se aos 2 centrais por filamentos radiais (Figura 2). (OLIVEIRA, et al., 2006).

Figura 2: Feixe de microtúbulos e proteínas associadas que formam o cerne de cílios e flagelos em uma célula eucariótica, responsável pelos seus movimentos

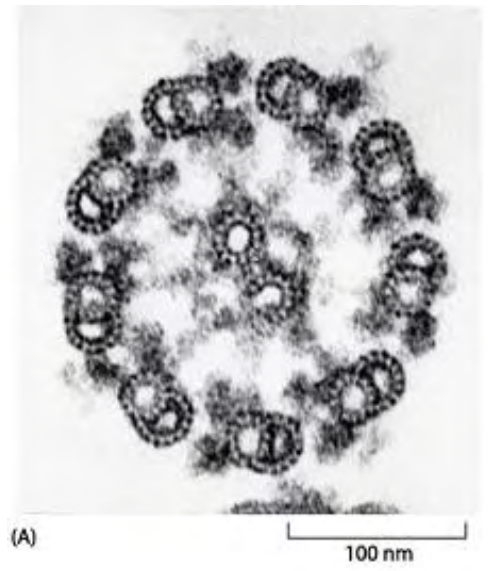

Fonte: (Alberts, 2011).

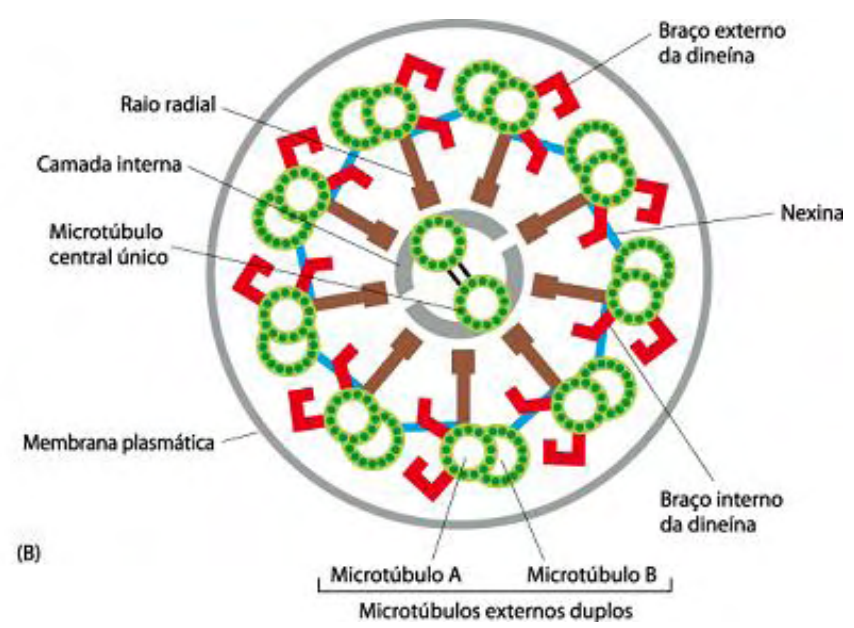

Legenda: (A)Microfotografia eletrônica de um flagelo, mostrando em secção transversal, a organização característica de microtúbulos "9+2". (B) Diagrama das partes de um flagelo ou cílio. As várias projeções que partem dos microtúbulos ligam estas estruturas entre si e apresentam-se em intervalos regulares em todo o comprimento do axonema. 
De cada microtúbulo emergem 2 braços de dineína, que são ATPases responsáveis pelo deslizamento entre os pares periféricos de microtúbulos e que originam o movimento flagelar (o ATP vem das mitocôndrias) (OLIVEIRA, et al., 2006). De um modo geral são necessários de 4 a 5 ciclos para que um processo espermatogênico se complete em mamíferos, ou seja desde a espermatogônia tipo A1 até a liberação dos espermatozoides no lumen do túbulo seminífero (CHIEREGATTO, 2005).

Estudos acerca do esperma de mamíferos indicou que os componentes da membrana plasmática são importantes para o movimento do espermatozoide para o local de fertilização e que a integridade funcional da membrana plasmática é um aspecto crucial na motilidade espermática, capacitação e metabolismo do espermatozoide (FRASER e AHUJA, 1988). O cálcio juntamente com ATP são considerados potenciais reguladores da motilidade espermática (LINDEMANN e GIBBONS, 1975; AOKI, SAKAI e KOHMOTO, 1999). O papel do cálcio se mostrou de elevada importância na sinalização da regulação da motilidade do espermatozoide, sendo sua falta ou insuficiência capaz de alterar negativamente a movimentação espermática e a capacitação da região acrossômica (SI e OKUNO, 1999; BELTRAN, et al., 2007).

O rato possui todas as glândulas acessórias, e mais glândulas coaguladoras que são responsáveis por promover uma coagulação temporária no ejaculado e glândulas prepuciais. As duas vesículas seminais são assim denominadas devido a um erro inicial de conceito de que eram ali reservados os espermatozoides. São arranjadas em múltiplos lóbulos e com um sistema ramificado de ductos, lembrando quando cortadas um favo de mel (SILVA, 2007).

Como já mencionado anteriormente, o processo reprodutivo nos mamíferos é cíclico, sendo composto de várias fases, podendo-se considerar que um ciclo completo reprodutivo se inicia com a produção de gametas, sendo considerado satisfatório, após a avaliação da capacidade do indivíduo de gerar novos indivíduos (Figura 3). Vale ressaltar que os estágios do ciclo reprodutivo são similares em mamíferos machos ou fêmeas, com exceção da produção de gametas, que em fêmeas os oócitos primários são formados no período prénatal, durante o desenvolvimento intra-uterino, enquanto que em machos isso só acontece na fase pós-natal (LEMONICA, 2008). 
Figura 3: Ciclo reprodutivo de mamíferos

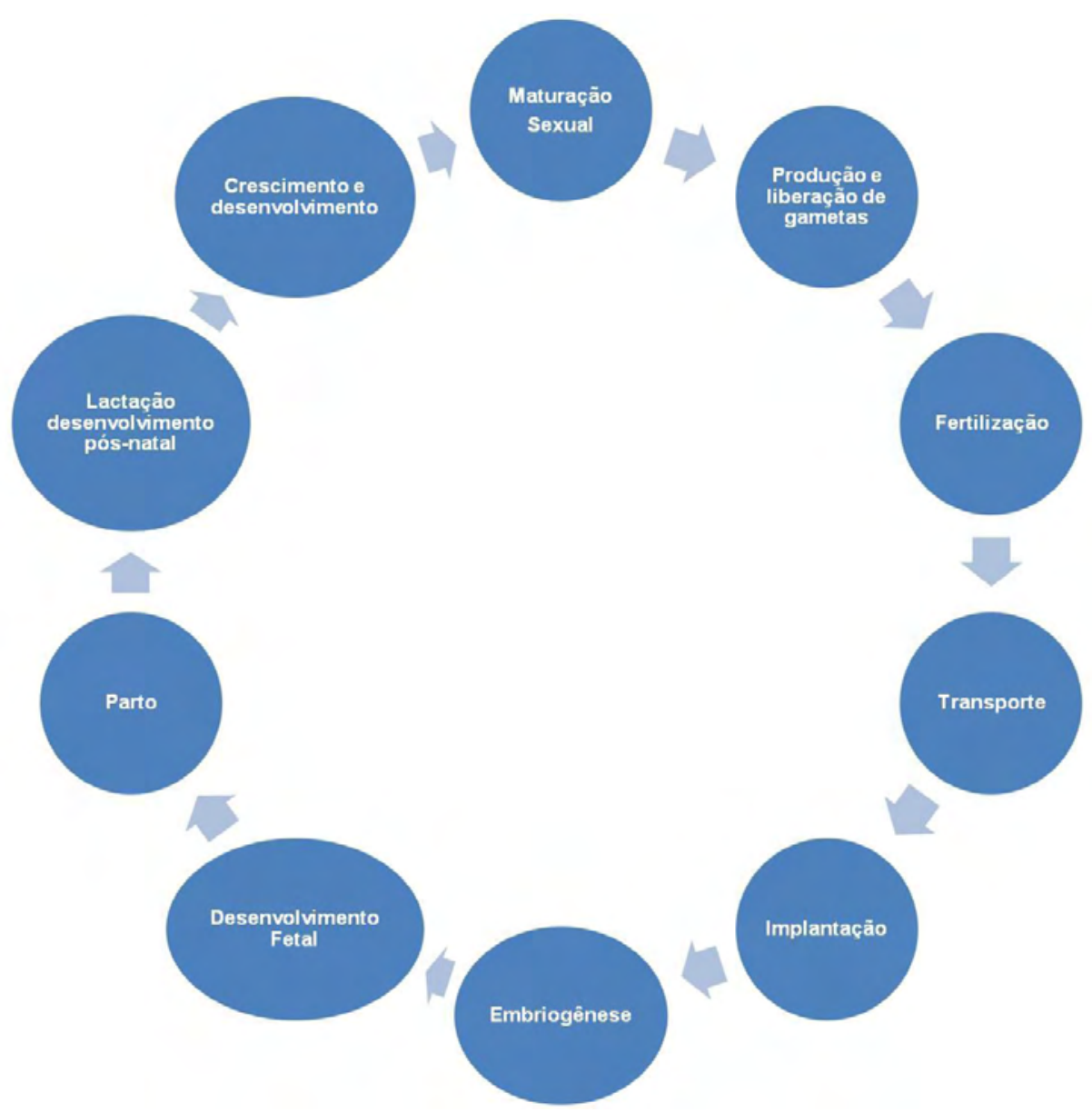

Fonte: (Adaptado de LEMONICA, 2008).

A toxicologia reprodutiva estuda efeitos toxicológicos de determinadas substâncias sobre a prole. A Food and Drugs Administration (FDA) preconiza a realização de testes de toxidade reprodutiva para estudar e conhecer os efeitos de uma substância química sobre o processo de reprodução dos mamíferos. Tais estudos, geralmente, compreendem a exposição de animais sexualmente maduros antes da concepção, durante o desenvolvimento pré-natal e após 0 nascimento e, continuadamente até sua maturação sexual, dependendo do protocolo experimental (SILVA LIMA, 2014).

Os agentes químicos quanto aos seus efeitos adversos sobre o ciclo reprodutivo se agrupam em duas categorias:

$\checkmark$ Substâncias que agem no desenvolvimento intra-uterino da prole;

$\checkmark$ Substâncias que alteram no indivíduo (machos ou fêmeas) sua habilidade reprodutiva (LEMONICA, 2008). 
Akbarsha e Murugaian (2000), trataram ratos com extrato de folhas de Andrographis paniculata (Chirayta verde, Rei dos amargos, Bile da terra) em propilenoglicol por 48 dias e verificaram que houve um comprometimento acentuado na normalidade da espermatogênese que pode ser observado na avaliações histológicas a partir da desorganização do epitélio dos túbulos seminíferos.

Gwayi e Bernard, (2002) avaliaram diferentes valores de pH na motilidade e qualidade de espermatozoides de rato Wistar e determinaram um valor normal de $\mathrm{pH} 7,6$.

Sönmez, Türk e Yüce (2005), indicou em seu trabalho que a alta concentração de ácido ascórbico aumenta a concentração de espermatozoides no epidídimo e o nível sérico de testosterona de ratos. Portanto, a suplementação com ácido ascórbico pode melhorar a qualidade do sêmen.

Silveira-Barbetti, (2008), fazendo um estudo com amostras seminal de homens com varicole e de homens normais férteis, analisou a viscosidade onde a amostra foi aspirada em uma pipeta Pasteur e caso a saída do sêmen ocorresse em gotas individuais (sem formação de filamento), o mesmo era classificado como normal, e quando observada a presença de filamento espermático maior que $2 \mathrm{~cm}$ de extensão se considerou como viscosidade aumentada; o valor normal variou de 7,2 a 7,8. As amostras de sêmen normal apresentaram-se brancas, opalescentes e homogêneas, as amostras que diferiram deste padrão (brancas ou amarelas e translúcidas) foram consideradas alteradas.

\subsection{Alterações reprodutivas induzidas por Azadiractha indica}

Existem relatos de que a planta Neem (Azadiractha indica) a mais de 2.000 anos vem sendo utilizada popularmente por grupos étnicos na Nigéria e Índia para finalidades medicinais (AUTA e HASSAN, 2016).

De acordo com Sharma et al., (1996), o óleo das sementes de Neem em diferentes concentrações apresentou in vitro atividade contraceptiva, diminuindo a motilidade progressiva espermática, e provocando a morte dos espermatozoides, porém em um tempo considerado elevado pelos autores de duas horas para a morte de todas as células na concentração de $10 \mu \mathrm{g} / \mathrm{ml}$ como 
resultado da degeneração da membrana celular. $O$ efeito somente sobre a motilidade pode ser observado a partir da dose de $100 \mu \mathrm{g} / \mathrm{ml}$ com 1 hora de exposição dos espermatozoides.

Boeke, et al., (2004), relatou que um efeito importante em relação a exposição subaguda ao pó das folhas de Neem (Azadiractha indica) na habilidade reprodutiva em ratos machos foi a redução da contagem e motilidade dos espermatozoides, bem como uma porcentagem aumentada de espermatozoides malformados, com o tempo de exposição variando de $24-48$ dias.

Dimech, et al. (2006); Bueno et al., (2009); Kuntze, et al. (2012); mostraram que extrato aquoso de plantas com outras atividades terapêuticas atestadas administrado via oral em ratos Wistar não apresentaram nenhum efeito no sentido de prejudicar a fertilidade dos animais. Nestes animais, os túbulos seminíferos apresentaram citoarquitetura epitelial normal, constituídos por várias camadas de células germinativas. As células germinativas e espermatozoides nos túbulos seminíferos apresentaram morfologia normal e em diferentes estágios de desenvolvimento.

Dados apresentados por Aladakatti, et al., (2001) acerca dos resultados do tratamento com Azadirachta indica por 48 dias em ratos albinos via gavagem, resultou em diminuição da contagem total, na motilidade e velocidade dos espermatozoides, bem como a diminuição significativa no nível de frutose nos espermatozoides.

Muitos são os estudos que se concentram no extrato ou no óleo de semente de Neem, contudo é o extrato de suas folhas, que apresenta natureza hidrofílica se misturando imediatamente com água, bem como com os fluidos corporais. Nos estudos de Khillare e Shrivastav (2001) quando avaliado in vitro o efeito do extrato das folhas de Neem em várias concentrações de 1 a $50 \mathrm{mg}$ sobre as motilidade e viabilidade de espermatozoides humanos, este se mostrou eficaz no sentido de deixá-los completamente imóveis, a menor concentração onde aconteceu a morte de todos os espermatozoides no tempo testado de 20 segundos foi a de $3 \mathrm{mg}$ e a viabilidade dos espermatozoides foi verificada utilizando Eosina/Negrosina e o mesmo foi constatado.

Boeke, et al., (2004), relatou em seu trabalho que um efeito importante em relação a exposição subaguda ao pó das folhas de Neem (Azadiractha 
indica) na habilidade reprodutiva em ratos machos, foi a diminuição no peso da vesícula seminal e próstata, contudo com o tempo de exposição de 24 - 48 dias.

De acordo com Dehghan, Martin e Dehghanan, (2005), o extrato etanólico das sementes de Neem administrado via oral, na dose de $100 \mathrm{mg} / \mathrm{kg}$ de peso do animal por 15 dias causou uma considerável diminuição da motilidade espermática de camundongos, ainda segundo os autores a atividade da enzima (ATPase) na cabeça e na cauda do epidídimo de animais tratados, quando verificada, estava significativamente diminuída em relação ao grupo controle.

A administração via oral do extrato aquoso de Neem na dose $100 \mathrm{mg} / \mathrm{kg}$ por 28 dias em camundongos, causou uma desordem no epitélio germinativo do túbulo seminífero tendo sua histoarquitetura afetada, revelando desagregação do epitélio germinativo, condensação marginal da cromatina em espermátides arredondadas, ocorrência de células gigantes, mistura de tipos de células germinativas nos estágios diferentes da espermatogênese e degeneração em células germinativas. A motilidade e o número dos espermatozoides também foram negativamente afetados (MISHRA e SINGH, 2005).

Sathiyaraj, e colaboradores (2010), relataram que houve diminuição significativa nos pesos dos testículos, epidídimos e vesículas seminais de ratos Wistar, assim como redução relacionada com a dose na contagem de espermatozoides testiculares, contagem de espermatozoides do epidídimo e motilidade e contagem anormal de espermatozoides quando administrado 0 extrato aquoso de folhas de Neem a $250 \mathrm{mg} / \mathrm{kg}$ e $350 \mathrm{mg} / \mathrm{kg}$, respectivamente, durante um período de 30 dias por via oral.

Ojewale, et al., (2014) encontrou em seu experimento que o extrato etanólico das raízes de Pseudocedrela kotschyi, também membro da família Meliaceae, encontrada nas savanas da Nigéria, nas concentrações de 250 $\mathrm{mg} / \mathrm{kg}$ e $500 \mathrm{mg} / \mathrm{kg}$ quando administrado via oral (gavagem) dose única em camundongos Swiss macho com diabetes induzida por Alloxan, não apresentou nenhum efeito no sentido de prejudicar a integridade histológica do epitélio germinativo dos animais em nenhuma das doses administradas. Os autores observaram que os túbulos seminíferos apresentaram citoarquitetura epitelial normal, constituídos por várias camadas de células germinativas, sendo que 
estas e os espermatozoides nos túbulos seminíferos apresentaram morfologia normal e em diferentes estágios de desenvolvimento.

Em estudos realizados com o extrato aquoso das cinzas da madeira fresca de Neem administrado via oral por 35 dias em ratos Wistar machos, foi apresentado que a motilidade dos espermatozoides dos animais dos grupos tratados diminuia ao passo que a concentração da dose do extrato das cinzas aumentava, a análise histológica relatou que os animais que receberam a menor dose $(5 \mathrm{mg} / \mathrm{kg}$ ) apresentaram resultados dentro da normalidade com túbulos seminíferos de morfologia esperada e presença de células espermatogênicas, os que receberam a dose de concentração $50 \mathrm{mg} / \mathrm{kg}$ apresentaram espessamento na túnica albugínea e alguns túbulos seminíferos sem conteúdo celular ou com restos de processo necrótico, já na dose de $100 \mathrm{mg} / \mathrm{kg}$ os túbulos seminíferos apresentaram contornos irregulares e quantidades discretamente diminuídas de células espermatogênicas (AUTA e HASSAN, 2016).

Khillare e Shrivastav (2003), realizaram um estudo onde verificou-se a atividade espermicida de diferentes concentrações do extrato aquoso das folhas de Neem coletado em Nova Delhi - Índia, sob espermatozoides humanos expostos ao extrato por 20 segundos, neste tempo os autores constataram que foi necessário $3 \mathrm{mg}$ do extrato para imobilizar e matar no estudo in vitro $100 \%$ dos espermatozoides.

Lisanti, et al., (2016) avaliou o extrato aquoso de sementes e folhas de Neem (Azadirachta indica), e foi revelado que a motilidade e a viabilidade dos espermatozoides sofreram uma diminuição quando comparada ao grupo controle depois da administração das doses 2,5 e 5,0 mg/kg por 36 dias, via oral.

Segundo Katte, Rajyalakshmi e Aladakatti (2018), as concentrações 0.5, 1.0, 1.5, $2.0 \mathrm{~mm} / \mathrm{mL}$, do extrato de Neem quando testadas in vitro em espermatozoides de ratos Wistar, apenas nas duas maiores doses observou-se efeito dependente da dose no número de espermatozoides viáveis, causando danos a motilidade e viabilidade dessas células germinativas. Quando determinado o ATP total nos espermatozoides, afim de se solucionar a questão do declínio na motilidade espermática, não se constatou um declínio no mesmo; os autores acreditam que a causa na queda desta motilidade está relacionada com a integridade da membrana plasmática dos espermatozoides alterando vias bioquímicas da utilização de energia. 


\subsection{Parâmetros hematológicos de Ratos Wistar}

De acordo com Carvalho et al, (2009), ratos, como os demais mamíferos quando em bom estado de saúde, tendem a manter seu meio interno constante e um controle rigoroso dos limites de sua variação. Assim sendo, se conhecer valores dos diferentes parâmetros fisiológicos é critério significativo para a avaliação da homeostase e modificações induzidas por processos patológicos e para a avaliação dos resultados obtidos nos procedimentos experimentais.

É sabido que ratos podem apresentar variações de parâmetros fisiológicos sob a influência de fatores como sexo, linhagem, genótipo e podem ser influenciados ainda pela idade, dieta, manuseio e ambiente (CARVALHO, et al., 2009).

O hemograma dos ratos revelou uma monocitose, que indica um tráfego aumentado de monócitos a fim de manter o fornecimento de macrófagos, por conta de uma demanda tecidual para fagocitose de partículas macromoleculares, os mesmos sugeriram que tal processo pode ter sido causado por uma reação inflamatória respiratória dos animais, frente ao material utilizado como cama, ou causado por parasitas que tem em seu ciclo biológico uma fase pulmonar, por exemplo, o Nippostrongylus sp (CARVALHO, et al., 2009).

De acordo com Castello Branco, et al., (2011) os ratos, após os camundongos, são os animais de laboratório mais comumente utilizados em pesquisas científicas, representando cerca de $20 \%$ do número total dos animais. Contudo, se faz necessário que cada laboratório ou biotério estabeleça um conjunto próprio de valores de referências dos animais, de acordo com linhagem, sexo e idade. Baseado nesse conceito, os autores demonstraram em seu trabalho valores de referência para parâmetros hematológicos para ratos Wistar machos adultos saudáveis.

Os resultados do trabalho apresentaram pequenas variações individuais ao se avaliar cada parâmetro isoladamente. Os mesmos ainda ressaltaram a importância do conhecimento e a divulgação dos valores dos parâmetros fisiológicos dos animais de experimentação, que podem exibir variações influenciadas por vários fatores que devem ser levados em consideração nas pesquisas experimentais (CASTELLO BRANCO, et al., 2011). 
No trabalho de Lima et al., (2014), foi destacado que embora nos últimos anos esteja havendo um maior desenvolvimento de métodos alternativos ao uso de animais como, os métodos in vitro, os modelos animais ainda são, atualmente, os mais utilizados em vários campos da pesquisa biológica por apresentarem como principal vantagem o fornecimento de informações sobre o organismo como um todo, fato que não é obtido com outros métodos, dentro dessas circunstâncias o conhecimento dos parâmetros fisiológicos para cada espécie é importante, uma vez que serve como referência para a avaliação do estado de saúde, de modificações induzidas por processos patológicos e para a avaliação dos resultados obtidos nos procedimentos experimentais .

Os diversos parâmetros fisiológicos de animais de laboratório podem variar entre linhagens e cepas diferentes de uma dada espécie, bem como por fatores intrínsecos e extrínsecos. Sendo assim, é de suma necessidade que cada centro de pesquisa estabeleça os valores de referência para animais de acordo com a espécie, a dieta, a linhagem, o gênero e a idade, bem como a metodologia utilizada na análise dos parâmetros (LIMA et al., 2014).

No estudo de Monteiro, (2010) foi avaliado a toxicidade subaguda do extrato aquoso da Ipomoea asarifolia (salsa) em ratos Wistar machos. A avaliação de parâmetros hematológicos é um importante indicador da fisiologia e patologia nos animais e seus valores podem ser alterados pela ingestão de plantas tóxicas.

Em Rocha, et al., (2012) foi demonstrado os parâmetros hematológicos obtidos do soro de ratos Wistar, tratados com a dose de $2000 \mathrm{mg} / \mathrm{kg}$ do extrato hidroalcoólico de Pradosia huberi (casca doce ou pau doce). Os autores compararam o grupo experimental com seu grupo controle, e verificaram que os machos tratados registraram diminuições significativas $(p<0,05)$ dos níveis de hemácias, hemoglobina, hematócrito e plaquetas que pode indicar anemia, hemorragia recente ou retenção de líquido, causando hemodiluição. A contagem diminuída de plaquetas (trombocitopenia) pode resultar de uma série de situações patológicas, como a destruição aumentada dessas células, devido ao uso de certas drogas, a problemas imunes e a coagulação vascular.

Oliveira, et al., (2013), relataram em seu trabalho as médias dos parâmetros hematológicos obtidos do sangue total de ratos tratados com o chá das folhas de Morus nigra (Amoreira-negra, Amora, Amora-negra, Amora-preta, 
Amoreira, Amoreira-do-bicho-da-seda) durante 30 dias (subcrônica), os resultados demonstraram que de maneira geral, não foi observada variação significativa nos parâmetros hematológicos dos grupos tratados em relação ao controle $(p<0,05)$. Entretanto, um aumento no número de monócitos e uma diminuição do número de plaquetas foram observados no grupo experimental quando comparado com o controle, assim constatou-se que o chá das folhas de Morus nigra pode ser considerado de baixa toxicidade, pois a administração subcrônica durante o período de 30 dias por via oral não produziu mortes nem sinais de toxicidade nos animais, além disso não provocou alteração nos parâmetros hematológicos analisados.

Lipinski, et al., (2011) administraram diariamente por 6 meses para búfalos junto com a suplementação de milho moído com minerais, $2 \mathrm{~g}$ de torta de Neem e $2 \mathrm{~g}$ de alho desidratado. Os animais tiveram fezes e sangue coletados antes do início do tratamento e em mais dois momentos posteriores. $\mathrm{O}$ autores observaram a redução do hematócrito após o tratamento, porém este permaneceu dentro dos valores de referência.

Foram testadas por Coelho (2014), três dosagens da torta de Neem adicionada ao sal mineral ( 1,2 e 4\%), administradas por 126 dias para 32 ovinos da raça Lacaune gestantes e não gestantes divididos em quatro grupos sendo três grupos para os diferentes tratamentos e um controle, o qual recebeu somente sal mineral. Amostras de sangue foram colhidas a cada 21 dias para realização do hemograma completo e pode ser constatado que não houve qualquer interferência nos valores hematológicos destes animais.

\subsection{Alterações nas condições fisiológicas em mamíferos ocasionadas por espécies vegetais}

Foi relatado por Boeke, et al., (2004), toxicidade aguda de material não processado em animais, para uma ovelha que comeu folhas de Neem (Azadiractha indica). A ingestão resultou em sintomas nervosos como movimentos da cabeça, andar em círculos, dispneia, aumento da temperatura corporal, insuficiência hepática e timpanites. Os sintomas duraram 12 horas e foram seguidos pela morte do animal. Contudo em estudos posteriores a 
administração de seiva foliar causou efeito anti-ansiedade em ratos em doses baixas, enquanto que em altas doses não causou mesmo efeito.

Mariz, et al., (2006) tratou com doses únicas do extrato etanólico de Jatropha gossypiifolia L. (Pinhão-roxo) (1,2 g/kg; 1,8 g/kg; 2,7 g/kg; 4,0 g/kg e $5,0 \mathrm{~g} / \mathrm{kg}$ ) ratos Wistar machos e também realizou observação por 14 dias. Pode ser constatado pelos autores alguns óbitos na maior dose, na dose igual ou superior a 1,8 g/kg, logo nas primeiras 4 horas após o tratamento, foram observados sinais gerais de toxicidade: discreta piloereção, prostração, contorções abdominais e aumento da evacuação. Apenas entre machos sobreviventes à maior dose, o extrato administrado reduziu o consumo de alimentos de forma significativa.

Mendéz, et al., (2006), relataram em seu estudo com suínos machos da raça Landrace de 60-120 dias de idade que receberam os frutos maduros triturados de Melia azedarach L. (fam.Meliaceae) misturados na ração e administrados em doses de 5, 10, 15 e $20 \mathrm{~g}$ por $\mathrm{kg}$ de peso do animal $(\mathrm{g} / \mathrm{kg})$ que os animais que ingeriram a menor dose de frutos apresentaram diarreia discreta e recuperaram-se rapidamente. Nos suínos que receberam doses de 10 e $20 \mathrm{~g} / \mathrm{kg}$ e, em um animal que recebeu $15 \mathrm{~g} / \mathrm{kg}$ de frutos os sinais clínicos caracterizaramse por incoordenação, tremores musculares, gemidos e gritos, dificuldade para manter-se em pé, relutância para levantar-se, manutenção em decúbito esternal e hipotermia. O tempo decorrido entre a ingestão e o aparecimento dos sinais clínicos foi de 2-24 horas.

Cunha (2008), em seu trabalho avaliou em ratos Wistar machos a toxicidade induzida de extrato aquoso de Mascagnia rígida (Tinguí, Timbó e Pela-bucho) nas concentrações 1,6 ou 3,2 g/kg em dose única, via oral, sendo avaliados os sinais clínicos apresentados pelos mesmos que tiveram sintomatologia com presença de prostração, desconforto respiratório, tremores, pêlos arrepiados, cromodacriorreia, convulsão tônica e tônico-clônica. $\mathrm{Na}$ necropsia destes animais não foram observadas alterações macroscópicas nos órgãos avaliados cérebro, miocárdio, fígado e rins.

Segundo Lima Pedroso, (2010) o extrato aquoso de llex paraguariensis (Erva-mate) administrado via oral em ratos Wistar machos, por oito semanas não acarretou em qualquer diferença significativa na ingestão alimentar e hídrica, diurese, fezes e peso dos animais. 
No trabalho de Silva (2010), avaliou-se os efeitos da administração oral do extrato etanólico do Neem em ratas Wistar durante o período da gestação e lactação, a dose administrada por via oral foi de $1 \mathrm{~mL}, 2 \mathrm{~mL}$ e $3 \mathrm{~mL}$ em três concentrações (50, 100 e $200 \mathrm{mg} / \mathrm{kg}$ ). Os resultados não mostraram nenhum efeito nos sinais de toxicidade avaliados (diminuição da ingestão de alimentos, perda de massa corporal, sangramento vaginal, aborto, diarreia, piloereção, incoordenação motora e morte) ou no ganho de peso dos animais.

Na pesquisa de Gbotolorun, et al., (2008) os animais receberam por via oral $1 \mathrm{mg} / \mathrm{kg}$ do extrato etanólico das flores de Neem durante 5 dias, os resultados mostraram diarreia intensa e redução de $6,46 \%$ na massa corporal de ratas Wistar.

Pires Junior (2010), administrou via oral (gavagem) extrato hexânico de frutos $M$. azedarach (Meliaceae) sobre ratos Wistar (machos e fêmeas) e camundongos Swiss (machos e fêmeas) na dose $300 \mathrm{mg} / \mathrm{kg}$ e $2000 \mathrm{mg} / \mathrm{kg}$ por 14 dias. Os resultados mostraram que não houve diferença nos grupos testados de ratos Wistar em relação aos grupos controle quanto ao consumo de ração; entretanto, ao analisar os grupos dos camundongos Swiss macho com a dose de $2000 \mathrm{mg} / \mathrm{kg}$, os mesmos apresentaram menor consumo de ração em relação ao grupo controle avaliado. Em relação ao consumo de água os resultados mostram que foi maior nos grupos tratados com ambas as doses, apenas no grupo controle dos camundongos Swiss machos tratados com a dose de 2000 $\mathrm{mg} / \mathrm{kg}$ o consumo hídrico foi mais intenso.

Rocha et al., (2012) avaliou o efeito toxicológico do extrato hidroalcoólico de Pradosia huberi Ducke (Casca-doce, Pau-doce) em ratos Wistar que receberam uma única dose $(2000 \mathrm{mg} / \mathrm{kg})$ e observados por 14 dias e o mesmo apresentou baixa toxicidade aguda uma vez que não foram registrados sinal de toxicidade geral nem óbito durante todo o período experimental, contudo os machos tratados apresentaram diminuição no consumo de água e ração com comprometimento do peso corporal em relação ao grupo controle. 


\subsection{Parâmetros Histológicos normais de Fígado e Rins e alterações induzidas por plantas}

O fígado é uma glândula grande e lobada, revestida por uma cápsula delgada de tecido conjuntivo (Cápsula de Glisson) que se espessa no hilo, onde a veia porta e a artéria hepática penetram no fígado e por onde saem os ductos hepáticos direito e esquerdo e os linfáticos. Tais vasos e ductos são circundados por tecido conjuntivo ao longo de toda extensão. Nos espaços porta entre os lóbulos hepáticos se forma uma delicada rede de fibras reticulares que oferece suporte aos hepatócitos e células endoteliais dos capilares sinusóides (BACHA JR. e BACHA, 2003; JUNQUEIRA E CARNEIRO, 2004). Cada lobo hepático se divide em numerosos lóbulos clássicos que consistem de sinusóides e placas parenquimatosas (hepatócitos), organizadas radialmente ao redor de uma veia central (BACHA JR. e BACHA, 2003).

Os hepatócitos são células poliédricas, que em cortes corados por hematoxilina e eosina o citoplasma se apresenta eosinofílico, principalmente devido ao grande número de mitocôndrias e algum retículo endoplasmático liso. Sempre que dois hepatócitos se encontram, eles delimitam um espaço tubular entre si, chamado de canalículo biliar, que são delimitados apenas pela membrana plasmática de dois hepatócitos e possuem um pequeno número de microvilos em seu interior (JUNQUEIRA E CARNEIRO, 2004).

Os rins são glândulas tubulares compostas e altamente vascularizadas, circundadas por uma cápsula de tecido conjuntivo denso, que funcionam mantendo a composição dos fluidos corporais em nível constante e removendo resíduos (BACHA JR. e BACHA, 2003).

O rim tem a forma de um grão de feijão com uma borda convexa e outra côncava onde se situa o hilo, onde entram e saem vasos sanguíneos, entram nervos e saem os ureteres; é constituído pela cápsula de tecido conjuntivo, a zona cortical e a zona medular. As regiões cortical e medular são formados principalmente por numerosos túbulos uriníferos proximamente agrupados. $O$ cortéx e a medula se dispõem em uma ou mais conformações piramidais, as pirâmides renais, sendo o ápice de cada pirâmide chamado de papila renal. No cortéx, grupos de túbulos dispostos radialmente formam a parte radiada, que consiste em túbulos coletores e porções retas de néfrons. A parte retorcida se 
localiza entre os raios e consiste em corpúsculos renais e numerosos túbulos retorcidos proximais e distais (BACHA JR. e BACHA, 2003; JUNQUEIRA E CARNEIRO, 2004).

Os túbulos contorcidos proximais são mais longos que os distais e são a porção principal do cortéx, são distinguidos pelas bordas em escova de suas células epiteliais e pela aparência um pouco recortada da sua superfície apical de suas células. Os túbulos contorcidos distais possuem uma superfície lisa, e suas células não possuem borda em escova (BACHA JR. e BACHA, 2003).

Quando analisados em microscopia de luz geralmente a luz dos túbulos proximais aparece muito reduzida, a orla em escova mal conservada e os capilares colobados, devido a artefatos de técnica (JUNQUEIRA E CARNEIRO, 2004).

Cada corpúsculo renal consiste de uma cápsula de Bowman e um glomérulo, sendo a capa externa desta cápsula o epitélio capsular, uma camada escamosa simples; a camada interna é o epitélio glomerular, formada a partir de podócitos altamentente ramificados, que circundam as alças capilares do glomérulo. Nas preparações histológicas para microscopia de luz, não é possível distinguir os podócitos das células endoteliais adjacentes das alças capilares. Entre as camadas capsular e glomerular é o espaço urinário, sendo este último contínuo com o lúmen de um túbulo retorcido proximal no polo urinário de cada corpúsculo (BACHA JR. e BACHA, 2003).

A medula de cada rim é formada de túbulos coletores, segmentos espessos e finos das alças de Henle e numerosos vasos retos. As porções descendentes espessas das alças de Henle são continuações dos túbulos proximais e localizam próximo a junção corticomedular, estes são túbulos retos cujas células são revestidas por uma borda em escova. A porção ascendente espessa e reta de cada alça lembra o túbulo distal, com o qual é contínuo (BACHA JR. e BACHA, 2003).

Ratos Wistar machos tratados com diferentes doses dos fitoterápicos Soyfemme ${ }^{\circledR}$ e Isoflavine $\circledast$ em doses distintas 4,$3 ; 21,5$ e $43 \mathrm{mg} / \mathrm{kg}^{-1}$ por 70 dias, não apresentaram nenhum tipo de lesão histológica em fígado e rins, segundo Hollenbach, (2008).

Em um estudo de GLINSUKON, et al., (1986) foi administrado dose única de Nimbolida (tetrapernóide constituinte químico importante das folhas de Neem) 
- $500 \mathrm{mg} / \mathrm{kg}$, e ácido nimbico diluídos em DMSO, para camundongos Swuiss machos e fêmeas, ratos Fischer machos e hamsters dourados machos via oral por gavagem. Ao realizar análise histopatológica os autores notaram que os rins dos camundongos e hamsters apresentaram necrose tubular, no qual as células tubulares apresentavam processos necróticos com núcleos picnóticos, conteúdo citoplasmático quebrado, restos celulares e descamação. Já no fígado dos hamsters foram reveladas infiltração gordurosa e necrose.

No estudo de Mariz, et al., (2008) as análises histológicas do fígado de animais tratados com extrato etanólico de partes aéreas de Jatropha gossypiifolia L. (Pinhão - roxo), na dose de $5 \mathrm{~g} / \mathrm{kg}$ por 14 dias, apresentaram arquitetura lobular com veias hepáticas terminais de paredes finas, regularmente distribuídas, com a presença de moderada congestão venular associada a fenômenos de dilatação e congestão sinusoidais. No seio do lóbulo, os hepatócitos se apresentaram na grande extensão do parênquima como elementos isomorfos e foram também identificados raros e isolados focos de hepatocitólise; se pode notar também congestão venosa portal.

Ainda no mesmo estudo, nos rins dos animais não pode ser observado nenhuma alteração histológica aparente na maior dose de $5 \mathrm{~g} / \mathrm{kg}$, a arquitetura lobular estava preservada com pirâmides medulares recobertas por tecido cortical. O córtex apresentou glomérulos regularmente distribuídos, cápsula de Bowman fina, com espaço de refração artefatual além de tufos capilares finos e mesângio delicado. Os túbulos contorcidos proximais e distais e o segmento do ducto coletor não evidenciaram particularidades histológicas.

Cunha, (2008), avaliou a toxicidade do extrato aquoso de Mascagnia rígida (Tinguí, Timbó, Pela-bucho) dose única por via oral nas concentrações 1,6 ou $3,2 \mathrm{~g} / \mathrm{kg}$ e analises histopatológicas revelaram congestão moderada no fígado e o rim apresentou nefrose em região cortical.

No trabalho de Paz, et al., (2010) foi relatada a hepatotoxidade de Achyrocline satureioides (Lam) D.C (Macela do campo), em ratos albinos Wistar machos, que receberam no bebedouro infusão de flores da planta $(20 \mathrm{~g} / \mathrm{L}$ de água), durante 7 dias. As análises histopatológicas demonstraram áreas de hepatócitos maiores com citoplasma granuloso na região pericentrolobular. $\mathrm{Na}$ região peri-portal os hepatócitos estavam grandemente aumentados em volume, com citoplasma vacuolado e núcleo picnócitos e irregulares. O espaço-porta 
estava desorganizado com ductos biliares maiores com núcleos mais volumosos.

Pires Junior, et al., (2012), quando analisaram os efeitos do extrato hexânico de frutos de Melia azedarach (MELIACEAE), dose única, administrado via oral na concentrações de 300 mg/kg e 2000 mg/kg em camundongos machos e fêmeas Swiss, não encontraram alterações macroscópica ou microscópica no fígado e rins dos mesmos. Pessoa (2009), obteve os mesmos em resultados ao tratar ratas Wistar com produto piolhicida a base de extrato concentrado contendo Azadirachta indica L., (1\%) Carapa guianensis Aublet (3\%) e Saccharum officinarum L. (20\%), por 15 dias.

Lisanti, et al., (2018) ao administrar o extrato aquoso das sementes de Neem para camundongos machos via oral por 36 dias nas doses 0,25 e 0,50 $\mathrm{mg} / \mathrm{kg}$, e realizar análise histopatológica 36 dias após cessado o tratamento pode verificar degeneração nos hepatócitos.

Ashafa, Orekoya e Yakubu, (2012) para investigarem as implicações tóxicas do extrato da casca do caule etanólico de Azadirachta indica (Neem) a $50,100,200$ e $300 \mathrm{mg} / \mathrm{kg}$ de peso corporal em ratos Wistar, via oral por 21 dias realizou estudo morfológico em fígado e rins, e constatou um aumento no peso dos fígados dos animais relacionados ao aumento da dose do extrato, revelando uma relação dose dependente; já diferentemente em relação ao peso dos rins não houve uma variação significativa nos pesos dos órgãos quando comparados ao grupo controle.

Oliveira et al., (2016) analisaram os efeitos do extrato aquoso de Arachis hipoagea $\mathrm{L}$ (amendoim), administrados por oito semanas via oral em ratos Wistar submetidos a dietas normo e hiperlipídicas. Análises da histologia hepática demonstraram que os animais de ambos os sexos e os grupos (normo e hiperlipídicas) não apresentaram nenhuma alteração histopatológica hepática por conta da administração do extrato. 
3.JUSTIFICATIVA

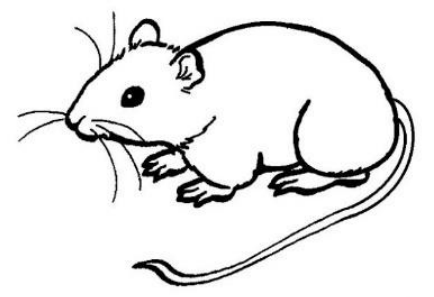




\section{JUSTIFICATIVA}

Nas últimas décadas com o aumento dos problemas da resistência de insetos a inseticidas sintéticos, e os transtornos advindos do uso indiscriminado de inseticidas sobre inimigos naturais, meio ambiente e o homem, e sobretudo 0 desenvolvimento da agricultura orgânica aumentou-se 0 interesse pelos inseticidas botânicos. Entretanto, há uma concepção errônea de que os inseticidas botânicos são sempre menos tóxicos ou mais seguros que os inseticidas sintéticos, bioinseticidas podem ser tóxicos a peixes, insetos benéficos (polinizadores, inimigos naturais de pragas) e mamíferos.

Uma lavoura muito importante no Brasil onde indica-se o uso de bioinseticidas é a de milho, onde dentre outras pragas, é atacada pela lagartado-cartucho Spodoptera frugiperda, um dos principais insetos-praga da cultura deste grão no país (GOUSSAIN, et al., 2002).

A lagarta-do-cartucho (Spodoptera frugiperda J.) destaca-se como importante praga da cultura do milho causando redução em mais de $25 \%$ da produtividade (SANTIAGO, et al., 2008). Em outras palavras, se faz necessário o uso de inseticidas para garantir a produção de alimentos em quantidade e qualidade suficientes, contudo se deve encontrar alternativas menos danosas aos organismos que serão expostos a tais produtos químicos e ao ambiente. Porém, é de suma importância que se conheça quais possíveis danos e/ou qualidades terapêuticas esses produtos alternativos podem causar principalmente em organismo de mamíferos.

Portanto, esta pesquisa visa avaliar os efeitos do extrato aquoso das folhas de Neem (Azadiractha indica) em ratos Wistar machos em idade reprodutiva, objetivando avaliar quais possíveis danos induzidos a exposição por oito dias ao extrato da planta pode resultar, trazendo respostas importantes afim de se conhecer esta importante alternativa ao uso de agrotóxicos sintéticos. 
4. HIPÓTESE

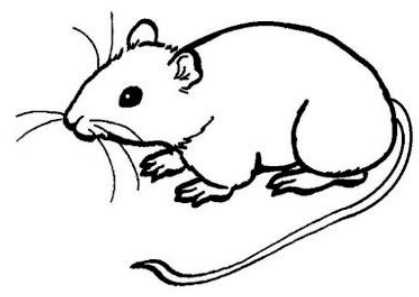




\section{HIPÓTESE}

O extrato aquoso das folhas do Neem (Azadiractha indica) apresenta atividade contraceptiva em machos de uma espécie de mamífero em oito dias de uso. 


\section{OBJETIVOS}

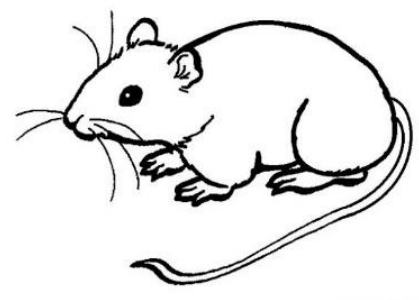




\section{OBJETIVOS}

\subsection{Objetivos gerais}

Esta pesquisa tem como objetivo analisar a dose resposta do extrato aquoso de Neem (Azadirachta indica) nas concentrações 5.000, 7.500 e 10.000 ppm administrados via oral em ratos Wistar (Rattus novergicus) machos em idade reprodutiva.

\subsection{Objetivos específicos:}

$>$ Reconhecimento de sinais clínicos de toxicidade nos animais após a administração das diferentes doses do composto;

> Investigação das alterações fisiológicas após administração do composto;

> Análise da qualidade do sêmen;

- Avaliação macro e microscópicas dos órgãos alvo fígado, rins e testículos;

> Verificar a capacidade contraceptiva do extrato na concentração e no tempo de administração ofertados aos animais. 
6. METODOLOGIA

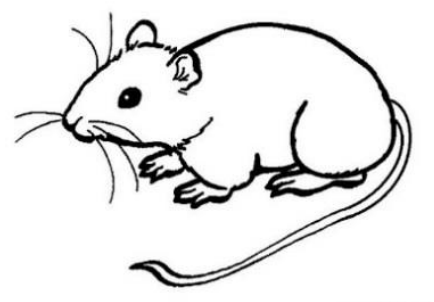




\section{METODOLOGIA}

O presente projeto foi conduzido no Laboratório de Imuno-histoquímica e Fisiologia Experimental (LIFE) do Departamento de Medicina Veterinária da Faculdade de Zootecnia e Engenharia de Alimentos da Universidade de São Paulo (FZEA - USP). Todos os procedimentos envolvendo os animais foram aprovados pelo Comitê de Ética no Uso de Animais - CEUA da Faculdade de Zootecnia e Engenharia de Alimentos da Universidade de São Paulo (FZEA USP) (CEUA № 4045041016).

Para esta pesquisa utilizamos 20 ratos Wistar adultos em fase reprodutiva oriundos do biotério do Biotério do Departamento de Ciências Básicas da Faculdade de Zootecnia e Engenharia de Alimentos da Universidade de São Paulo. Os animais foram mantidos em ambiente com ciclo claro-escuro de 12 horas, em caixas em polipropileno para ratos $(41 \times 34 \times 16 \mathrm{~cm})$ com tampa alta em arame de aço inox (Modelo BHGAACC, BEIRAMAR IND E COMÉRCIO LTDA), providas de cama de maravalha esterilizada em autoclave com oferta de água em bebedouros e comida (ração peletizada) ad libitum durante todo 0 experimento (Figura 4). 
Figura 4: Fluxograma experimental do projeto

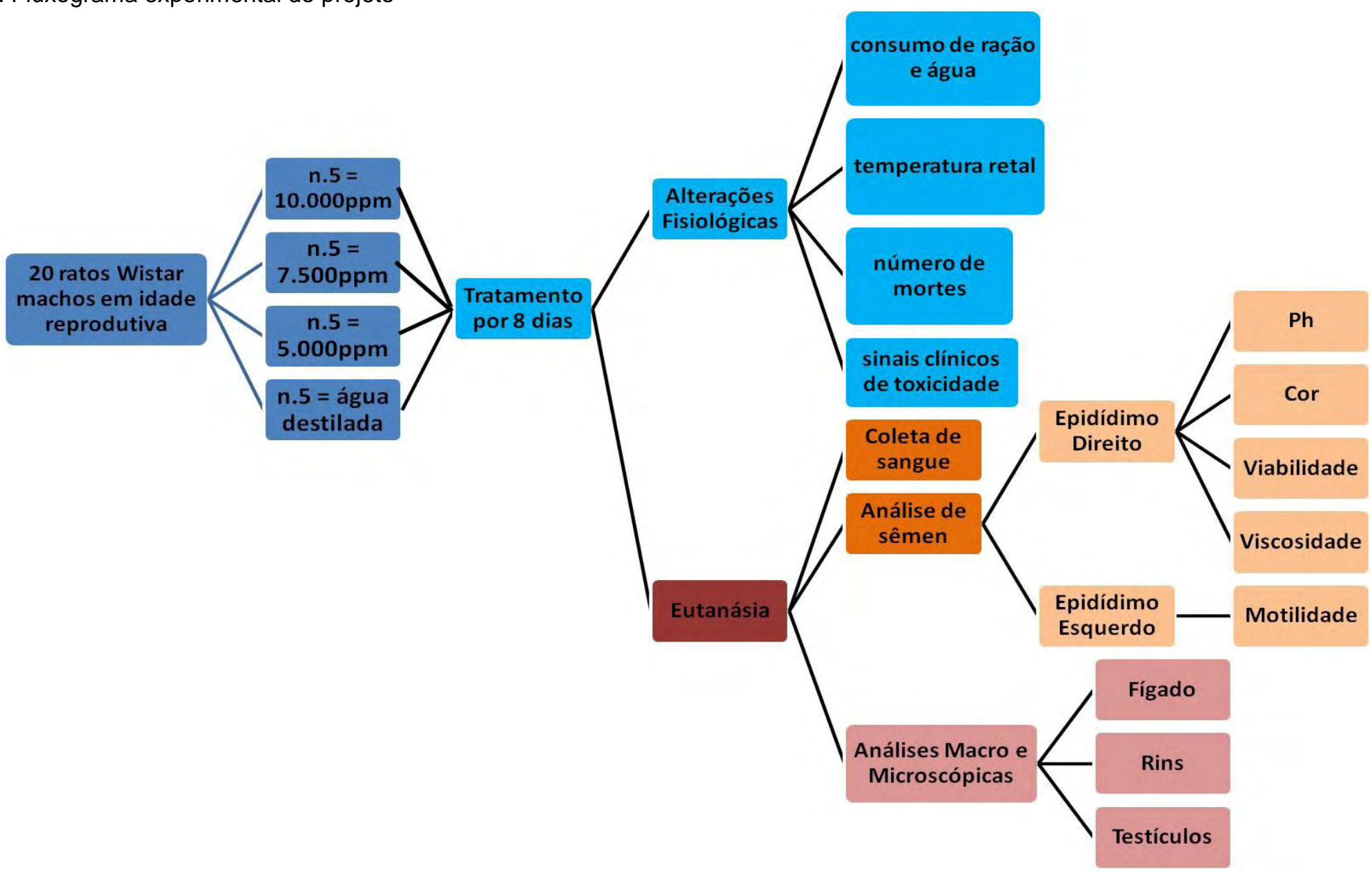

Fonte: (Cardoso, C.A., 2018). 


\subsection{Coleta das folhas, obtenção do extrato aquoso de Azadirachta indica e Tratamento dos animais com extrato aquoso}

O material vegetal (folhas) foi coletado da CPMA (Coleção de Plantas Medicinais e Aromáticas) no Centro Pluridisciplinar de Pesquisas Químicas, Biológicas e Agrícolas (CPQBA) da Universidade de Campinas (Unicamp), localizada no município de Paulínia/SP, cuja classificação do clima segundo a escala Köppen e Geiger é Cfa que traduz um clima temperado úmido com verão quente, a temperatura média é $19.9^{\circ} \mathrm{C}$ e a pluviosidade média anual é $1291 \mathrm{~mm}$.

Após a coleta, o material foi selecionado, limpo e pesado, sendo em seguida submetido ao processo de secagem em estufa de ar circulante por aproximadamente $24 \mathrm{~h}$, até as folhas ficarem desidratadas e quebradiças. Com o auxílio de um moinho, as mesmas foram moídas, para a obtenção do pó, que foi utilizado no preparo do extrato.

Para o preparo do extrato aquoso foram colocadas $150 \mathrm{~g}$ do pó das folhas por litro de água, seguidamente houve a mistura do pó na água por agitação, posteriormente a mistura foi deixada em maceração em água em temperatura ambiente por 24 horas. Após esse período, a mistura foi filtrada e armazenada em geladeira até o momento do uso, seguindo metodologia desenvolvida por Viana e Ribeiro, (2010).

O extrato produzido estava na concentração de 10.000 ppm, para se obter as outras duas concentrações (7.500 ppm e 5.000 ppm) foram separadas alíquotas e diluídas com água destilada em quantidades previamente calculadas.

Para emprego do extrato, utilizamos animais com idade a partir de 78 dias de vida; os animais foram divididos em 4 grupos compostos por 5 animais cada, sendo: G1 - 10.000ppm, G2 - 7.500ppm, G3 - 5.000 ppm e G4 - controle com água destilada. Estas concentrações foram estabelecidas a fim de analisar os efeitos oriundos das concentrações utilizadas em lavoura de milho (Zea mays) no Brasil para o controle da lagarta-do-cartucho (Spodoptera frugiperda). 0 volume administrado foi padronizado em $1 \mathrm{ml}$ para cada animal e a administração deu-se por gavagem. 


\subsection{Alterações Fisiológicas}

\subsubsection{Verificação de peso, consumo de ração e água, temperatura retal}

Para verificação de peso, consumo de ração e água e temperatura retal utilizamos o procedimento exposto por Silva, et al., 2005; assim para cada animal disponibilizamos 200 gramas de ração e $500 \mathrm{ml}$ de água. A pesagem dos animais deu-se em dias alternados, utilizando balança analítica digital Unicasa ${ }^{\circledR}$. $\mathrm{O}$ consumo de água e ração foi quantificado a cada 24 horas; para quantificação de consumo de água utilizamos uma proveta graduada e para o consumo de ração utilizamos a pesagem do alimento em balança analítica digital.

A temperatura foi verificada diariamente durante o experimento por termometria retal com uso de termômetro digital, como descrito na metodologia de Koproski e Pachaly (2017). Após o uso o termômetro era limpo com água destilada duas vezes e ao final das medições do dia era limpo com gaze e álcool $70 \%$ hidratado.

\subsubsection{Avaliação de sinais clínicos de toxicidade}

Durante o período experimental de 8 dias os animais foram observados diariamente quanto aos sinais clínicos de toxicidade, incluindo: postura, convulsões/tremores, consistência e aspecto das fezes, piloereção, aspecto da pele e pêlos, estresse, salivação, olhos e comportamento, seguindo a metodologia descrita por Sachetti et al. (2009).

\subsection{Eutanásia e procedimento cirúrgico}

O procedimento de eutanásia deu-se através da combinação de utilização de anestésicos e câmara de $\mathrm{Co}_{2}$. Para a eutanásia os animais foram deixados em jejum de 12 horas e seguidamente foram anestesiados com a combinação de Ketamina (20 mg/kg- 0,2 mL), Xilazina (1 mg/kg - 0,05 mL) mais analgesia com Tramal (1 mg/kg - 0,05 mL) por via intraperitoneal.

Os animais anestesiados foram posicionados em decúbito dorsal sobre uma bandeja de parafina de $30 \times 35 \mathrm{~cm}$ e para a coleta dos materiais realizamos antissepsia da região pélvica com gaze e álcool 70\%. Após realizada tricotomia, acessamos longitudinalmente 0 escroto, com aproximadamente dois 
centímetros, na metade inferior esquerda, seguida de abertura de todos os planos até a exposição do testículo e epidídimo, conforme descrito por Weber, (1998).

Em seguida realizamos a colheita de sêmen dos epidídimos, retirada total dos testículos e a colheita do sangue por punção cardíaca, o qual foi armazenado em tubos de $0,5 \mathrm{~mL}$ contendo EDTA e reservados em caixa de isopor contendo gelo reciclável para posterior análise. Findadas as coletas o animal sofreu exposição ao $\mathrm{CO}_{2}$ até a completa perda de consciência, posteriormente realizamos análise para confirmar a morte dos animais que consistiu em avaliar a ausência de movimento respiratório; ausência de batimentos cardíacos, ausência de pulsação, mucosas pálidas e perda de reflexos. Após constatada a morte do animal procedeu-se a retirada dos outros órgãos para posterior avaliação histológica.

\subsection{Análise da qualidade do sêmen}

\subsubsection{Avaliação macroscópica do sêmen}

Foi realizado o procedimento de colheita de esperma da cauda do epidídimo, através da execução de uma pressão com os dedos de modo a facilitar a retirada do material. A túnica epididimária foi incisada expondo o ducto epididimário, seguido de uma secção transversal completa do mesmo, a coleta do esperma deu-se com palito de ponta fina de madeira com $6,5 \mathrm{~cm}$ de comprimento.

O material coletado do epidídimo esquerdo foi colocado em tubo de eppendorf, contendo cloreto de sódio a 0,9\%, (1:5) para a análise da motilidade dos espermatozoides.

O sêmen retirado da cauda do epidídimo direito foi utilizado para se verificar a cor visualmente, a consistência a partir da viscosidade e o $\mathrm{pH}$ que foi medido por meio de papel indicador de pH (WEBER, 1998; ARCURI, 2015; LISANTI, et al., 2016). 


\subsubsection{Motilidade dos espermatozoides}

A análise de motilidade foi realizada imediatamente após a retirada do sêmen do epidídimo do animal, a fim de limitar os efeitos deletérios de $\mathrm{pH}$ ou alterações de temperatura na motilidade.

Para esta análise misturamos uma aliquota de sêmen contendo espermatozoides da cauda epidimária esquerda com $25 \mu l$ de solução salina (cloreto de sódio a 0,9 \%/1:5) em um eppendorf. A mistura foi delicadamente homogeneizada, seguida da retirada de uma amostra de $10 \mu \mathrm{l}$, o qual foi colocada em lâmina e coberta com lamínula; a observação foi realizada em microscópio de luz em objetiva de 40, 5 campos distintos foram visualizados e 200 espermatozoides avaliados e contados, seguindo a metodologia estabelecida por Halvaei, Roodsari e Harat (2012) e Lisanti, et al. (2016).

A seleção de campos para avaliação da motilidade dos espermatozoides foram de pelo menos a $5 \mathrm{~mm}$ das bordas da lamínula conforme descrito pela OMS - Organização Mundial da Saúde (2010) como pode ser visualizado na Figura 5.

Figura 5: Método de seleção de campos para avaliação da motilidade

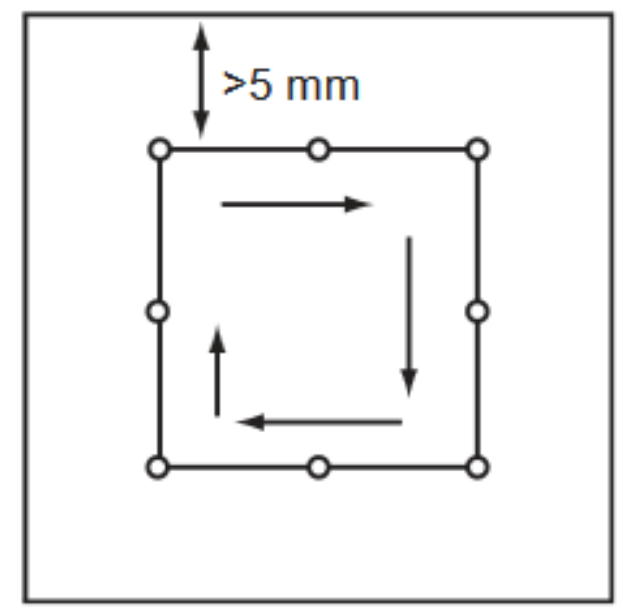

Fonte: (Organização Nacional da Saúde (OMS), (2010, p. 24)

O volume da solução de sêmen e as dimensões da lamínula foram padronizadas, para que os espermatozoides pudessem nadar livremente. Para um volume de $10 \mu \mathrm{l}$ pipetada da amostra e colocada na lâmina, foi utilizada lamínula de $22 \times 22 \mathrm{~mm}$, o que criou um espaço de profundidade de $20.7 \mu \mathrm{m}$. 
A motilidade dos espermatozoides foi avaliada de acordo com a classificação da OMS - Organização Mundial da Saúde (2010), o qual divide-se em 3 categorias:

> Motilidade Progressiva: os espermatozoides se movem ativamente, de forma linear ou círculo grande, independentemente da velocidade;

> Motilidade não progressiva: todos os outros padrões de motilidade com ausência de progressão, nada em pequenos círculos, a força flagelante quase não desloca a cabeça, ou quando desloca apresenta apenas um batimento flagelar;

$>$ Imóveis: Não apresenta nenhum movimento.

\subsubsection{Avaliação da viabilidade do sêmen}

Foi conduzida segundo protocolo estabelecido pela OMS (Organização Mundial da Saúde - Manual de laboratório para processamento e avaliação de sêmen) com pequenas adaptações.

Preparo dos reagentes:

- $\mathrm{NaCl}$ 0,9\%: dissolvido em 0,9 g de $\mathrm{NaCl}$ em $100 \mathrm{ml}$ de água destilada;

- Eosina 0,5\%: dissolvido em 0,5 g de eosina (índice de cor 45380) em $100 \mathrm{ml}$ de $\mathrm{NaCl}$ a $0,9 \%$.

1. Foi retirada uma alíquota de $5 \mu \mathrm{l}$ de sêmen e misturado com $5 \mu \mathrm{l}$ de solução de eosina/ $\mathrm{NaCl}$ em uma lâmina.

2 . Após misturou-se com uma ponteira de pipeta e cobriu-se com uma lamínula de $22 \mathrm{~mm} \times 22 \mathrm{~mm}$ e deixado em repouso por 30 segundos. A amostra de sêmen foi então remixada e retirada uma alíquota replicada, que foi misturada com eosina e foram refeitos os passos 1 e 2 anteriores.

Se observou no microscópio e se realizou uma contagem de 100 espermatozoides em 4 ou 5 campos.

Foi identificado e indicado o número de espermatozoides:

$\checkmark$ Viáveis (não adquirem cor, mas movimento é observado); 
$\checkmark$ Pouco viáveis (adquirem cor, e movimento é observado);

$\checkmark$ Não viáveis (adquirem cor, e movimento não é observado);

$\checkmark$ Inviáveis (não adquirem cor, mas não é observado movimento).

\subsubsection{Cor}

A cor do sêmen foi analisada, segundo Mosaferi, et al. (2004), por meio de avaliação visual e registradas de acordo com a descrição da OMS, (2010).

D Branco Opalescente - tonalidade leitosa (normal);

$>\quad$ Amarelo (pioespermia) - presença de vitaminas ou drogas;

$>\quad$ Marrom-averrmelhado (hemospermia) - presença de glóbulos vermelhos.

\subsubsection{Consistência a partir da viscosidade}

Para avaliação da consistência a partir da viscosidade utilizamos a metodologia descrita pela OMS (2010) e Moreira da Silva (2012), com adaptações que consistiu em introduzir um palito de madeira dentro da amostra acondicionada em tubo eppendorf e a observação do comprimento do fio de sêmen formado após a retirada do palito; as amostras eram classificadas seguindo a escala abaixo:

> Viscosidade normal = adere ao palito, sem formação de filamento . Viscosidade aumentada $=$ formação de filamento de aproximadamente $2 \mathrm{~cm}$.

$>$ Viscosidade diminuída $=$ não adere ao palito .

$>$ Viscosidade anormal $=$ filamento excede $2 \mathrm{~cm}$.

\subsection{5. $\mathrm{pH}$}

A metodologia para avaliação do $\mathrm{pH}$ das amostras foi realizada seguindo o descrito por Alvarez, et al. (2006) e OMS, (2010). As amostras foram medidas em um tempo uniforme, sempre menor que 30 minutos após a colheita, utilizando-se papel de pH na faixa de 0,0 a 14,0. A metodologia consistiu em espalhar uma gota de sêmen uniformemente sobre o papel de $\mathrm{pH}$ com o auxílio do palito de madeira e aguardar até que a cor da zona impregnada se tornasse uniforme (<30 segundos). O resultado obtido era então comparado com a cor da tira de calibração do kit (Fusion- Universal pH 0 -14). 


\subsection{Análise sanguínea}

As analises sanguíneas foram realizadas no Laboratório Clínico Veterinário na Unidade Didático Clinico Hospitalar do Departamento de Medicina Veterinária da Faculdade de Zootecnia e Engenharia de Alimentos da Universidade de São Paulo - FZEA/USP.

A coleta de sangue por punção cardíaca deu-se com o animal anestesiado e posicionado em decúbito dorsal. Introduzimos uma agulha perpendicular logo abaixo da cartilagem xifoide, atingindo a base do coração. Seguidamente fez-se uma sucção leve para aspiração de $0,5 \mathrm{ml}$ de sangue, 0 qual foi depositado em tubos de coleta com EDTA e armazenado em caixa de isopor com gelo reciclável. Após realizada a coleta de sangue os animais seguiram imediatamente para a câmera de $\mathrm{CO}_{2}$ para procedermos a eutanásia.

Para o estudo hematológico avaliamos: leucócitos totais, hemácias, hemoglobina, hematócrito, índices hematimétrico e plaquetas, as quais foram realizadas através de metodologia automatizada (Equipamento Mindray BC2800 Vet, China). A contagem diferencial de leucócitos e morfologia celular, foram realizadas através de metodologia manual (Coloração: Rosenfeld método May-Grunwald-Giemsa modificado) e a dosagem de proteína plasmática foi realizada por refratometria. Para cada parâmetro avaliado, os valores foram expressos em média e desvio padrão.

\subsection{Avaliação macro e microscópica dos órgãos alvo}

Os órgãos alvo estudados foram fígado, rins e testículos, sendo os mesmos removidos após a eutanásia dos animais. Para avaliação macroscópica os órgãos foram retirados, e tiveram a sua massa úmida determinada em balança digital Unicasa ${ }^{\circledR}$ seguidamente foram clivados e imersos em fixadores específicos para cada órgão, sendo: testículo: líquido de Bouin, fixados durante 24 horas em geladeira e o fígado e rins: solução de formaldeído à 10\% fixados por 24 horas em temperatura ambiente. Após o período de fixação os testículos foram lavados abundantemente e como fígado e rins foram levados para recipientes com álcool $70 \%$ até processamento histológico, seguindo a metodologia descrita por Dimech (2006) e Bandiera (2015). 


\subsubsection{Processamento histológico do testículo}

A análise histológica dos testículos deu-se a fim de analisarmos a citoarquitetura e a presença de espermatozoides no túbulos seminíferos. Os testículos pré-fixado em Bouin foram seccionados ao meio de forma transversal para análise histopatológica. O órgão foi desidratado em solução crescente de etanol de $70 \%$ a $95 \%$ durante 45 minutos cada e dois banhos de álcool 100\% 45 minutos cada. Na etapa de diafanização, os órgãos foram imersos em uma solução de álcool e xilol 1:1 durante 45 minutos, seguido de três banhos de xilol $100 \%$ de 45 minutos cada. Posteriormente as amostras foram submetidas a dois banhos de parafina purificada em estufa a $70^{\circ} \mathrm{C}$ durante 1 hora cada.

Seguidamente o material foi incluso em blocos de parafina com cera de abelha mais ácido esteárico puríssimo, e em seguida refrigerados. Foram feitos cortes não consecutivos (a cada dois ou três cortes) de $3 \mu \mathrm{m}$ de espessura utilizando micrótomo (Marca Slee, modelo CUT 5062). As lâminas foram desparafinadas em estufa a $70^{\circ} \mathrm{C}$ e submetidas a dois banhos de xilol, de 15 minutos cada. Em seguida foram imersas em soluções decrescentes de álcool $100 \%, 95 \%$ e $70 \%$ (5 minutos cada), coradas com hematoxilina/eosina (H\&E), seguida de imersão em soluções crescentes de álcool (70\% até 100\%, e xilol intermediário, diafanizado e montável.)

Por fim, as lâminas foram aderidas em lamínula utilizando permaute transparente e três lâminas de cada animal foram analisadas utilizando microscópio de luz (Marca Olympus) em aumento de 400X.

\subsubsection{Processamento histológico do fígado e rins}

Para análise histopatológica os tecidos foram inicialmente desidratados em diferentes concentrações de álcoois, passaram por clareamento com xilol e foram impregnados com parafina, seguindo o procedimento histológico convencional. Após inclusão em parafina, os tecidos foram seccionados em micrótomo em cortes de $3 \mu \mathrm{m}$ de espessura com intervalo de $50 \mu \mathrm{m}$ entre os cortes. Cada lâmina foi corada com hematoxilina/eosina e foram observados 10 campos de cada corte (60 campos por animal) em microscópio (Marca Olympus). 
As alterações consideradas basearam-se no descrito por Bandeira (2015), no tecido hepático foram consideradas alterações como: presença de células inflamatórias, degeneração hidrópica, tumefação celular, alargamento sinusoide, congestão vascular, infiltrado perivascular e necrose. Para os rins foram considerados os seguintes parâmetros: espaço de filtração aumentado ou reduzido, tumefação medular e cortical, congestão vascular cortical, vacuolização citoplasmática, presença de células inflamatórias, dilatação do túbulo contorcido distal, presença de material hialino e necrose.

\subsection{Análise de dados}

Para analisar os resultados obtidos dos parâmetros fisiológicos e hematológicos e determinação de massa úmida foram realizadas a médias, o erro padrão e Anova seguida de Teste de Hartley para testar as igualdade das variâncias dos tratamentos, sendo considerado o nível de significância $p(0,05)$ e valor F máximo de Hartley $(13,70)$. Para verificar as pressuposições da ANOVA foi utilizado o módulo SAS/LAB.

Os resultados de motilidade e viabilidade espermática foram expressos em porcentagem. 
7. RESULTADOS

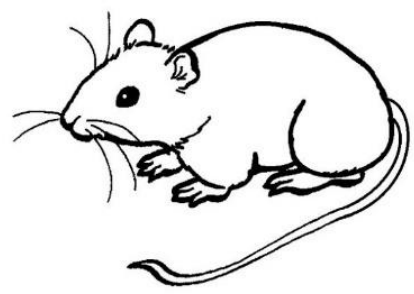




\section{RESULTADOS}

\subsection{Alterações Fisiológicas}

Os resultados obtidos revelam que os animais não apresentaram sinais de intoxicação frente ao tempo e via de administração empregados na avaliação que pudessem alterar de forma negativa sua fisiologia.

Nossos resultados mostram que todos os animais apresentaram peso médio variando entre $292,70 \mathrm{~g}$ a $312,35 \mathrm{~g}$, temperatura retal variou entre $36,0 \stackrel{\circ}{ } \mathrm{C}$ a $36,06 \stackrel{\circ}{\circ}$, o consumo de ração variou entre $46,85 \mathrm{~g}$ a $49,35 \mathrm{~g}$, e o consumo de água teve uma variação entre 82,20 a $95,30 \mathrm{ml}$ (Tabela 1). Não foi revelada diferença significativa entre os tratamentos.

Tabela 1 - Médias de peso, consumo de ração e água e temperatura retal dos ratos Wistar expostos a diferentes concentrações de extrato aquoso de Neem.

\begin{tabular}{|c|c|c|c|c|c|}
\hline \multirow[t]{3}{*}{ Alterações Fisiológicas } & \multicolumn{4}{|c|}{ GRUPO } & \multirow{3}{*}{$\begin{array}{c}\text { Erro } \\
\text { Padrão }\end{array}$} \\
\hline & Controle & 5.000 & 7.500 & 10.000ppm & \\
\hline & & ppm & ppm & & \\
\hline Peso médio (g) & 312,35 & 307,05 & 310,7 & 292,7 & $\pm 7,9875$ \\
\hline Consumo médio de & & & & & $\pm 1,1457$ \\
\hline ração $(\mathrm{g})$ & 48,40 & 47,95 & 49,35 & 46,85 & \\
\hline Consumo médio de água & & & & & $\pm 5,4273$ \\
\hline$(\mathrm{ml})$ & 82,20 & 95,30 & 89,00 & 90,25 & \\
\hline Temperatura média $\left({ }^{\circ} \mathrm{C}\right)$ & 36,0 & 36,0 & 36,03 & 36,06 & $\pm 0,1572$ \\
\hline
\end{tabular}

\subsection{Análise da qualidade do sêmen}

As análises mostraram que o sêmen apresentava cor branco opalescente com tonalidade leitosa; viscosidade normal, o sêmen ficava aderido ao palito, sem formação de filamento e o pH mensurado por fita indicou 7,0. Sendo assim, nossos resultados não revelaram nenhuma alteração nos grupos estudados. 


\subsubsection{Motilidade Espermática}

Com os resultados obtidos sobre a motilidade dos espermatozoides foi possível constatar efeito dose dependente, ou seja, observamos queda na motilidade ao passo que a dose administrada aumentava sua concentração. A motilidade progressiva pode ser observada nos grupos controle (99\%), 5.000 ppm (93\%) e 7.500 ppm (90\%). Enquanto que no grupo tratado 10.000 ppm os espermatozoides em sua grande maioria se apresentaram imóveis (95\%). A motilidade não progressiva, pode ser observada em todos os grupos teste e no controle, entretanto de maneira menos expressiva, tendo seu maior valor em porcentagem (10\%) sido constatado no tratamento de 7.500 ppm (Tabela 2).

Tabela 2: Porcentagens relacionada a motilidade dos espermatozoides em cada um dos grupos avaliados.

\begin{tabular}{|c|ccc|}
\hline \multirow{2}{*}{ Grupos } & \multicolumn{3}{|c|}{ Motilidade (\%) } \\
\cline { 2 - 4 } & Progressiva & $\begin{array}{c}\text { Não- } \\
\text { progressiva }\end{array}$ & Imóveis \\
Controle & 99 & 1 & 0 \\
$5.000 \mathrm{ppm}$ & 93 & 7 & 0 \\
$7.500 \mathrm{ppm}$ & 90 & 10 & 0 \\
10.000ppm & 0 & 5 & 95 \\
\hline
\end{tabular}

Fonte: (CARDOSO, C.A., 2018).

\subsubsection{Viabilidade Espermática}

Os resultados obtidos acerca da viabilidade dos espermatozoides demonstraram efeito dose dependente, ou seja, observamos queda na viabilidade ao passo que a dose administrada aumentava sua concentração. No grupo controle a grande maioria dos espermatozoides se encontravam viáveis $(98,6 \%)$, fato similar verificado no grupo $5.000 \mathrm{ppm}$, onde $(98,2 \%)$ dos espermatozoides estavam viáveis. No grupo tratado com extrato a concentração de 7.500 ppm (94,8\%) dos espermatozoides se encontravam viáveis, contudo no grupo de animais tratados com 10.000 ppm $(89,2 \%)$ dos espermatozoides estavam inviáveis como demonstra a Tabela 3 a seguir. 
Tabela 3: Porcentagens relacionada a viabilidade dos espermatozoides em cada um dos grupos avaliados.

\begin{tabular}{|c|cccc|}
\hline Grupos & \multicolumn{4}{|c|}{ Viabilidade (\%) } \\
\cline { 2 - 5 } & Viáveis & $\begin{array}{c}\text { Pouco } \\
\text { viáveis }\end{array}$ & Não viáveis & Inviáveis \\
Controle & 98,6 & 0 & 0 & 1,4 \\
$5.000 \mathrm{ppm}$ & 98,2 & 0 & 0 & 1,8 \\
$7.500 \mathrm{ppm}$ & 94,8 & 0,4 & 2,8 & 2 \\
10.000ppm & 0 & 0 & 10,8 & 89,2 \\
\hline
\end{tabular}

Fonte: (CARDOSO, C.A., 2018).

Figura 6: Fotomicrografias de espermatozoides ratos Wistar expostos a diferentes concentrações de extrato aquoso de neem
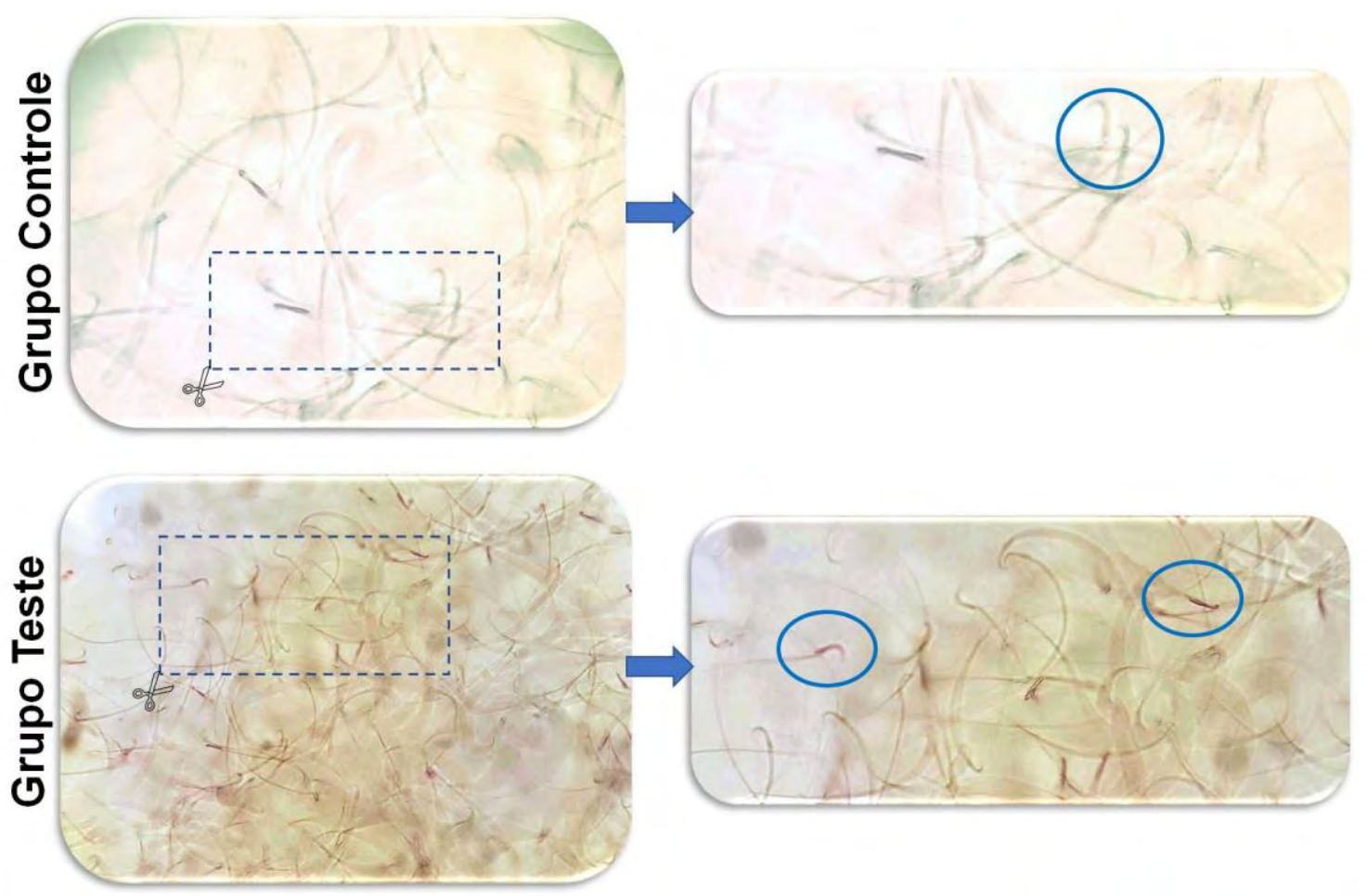

Fonte: (CARDOSO, C.A., 2018).

Legenda: Evidenciamos a cabeça do espermatozoide (circulo) de um rato Wistar pertencente ao Grupo Teste de 7.500 ppm corados com eosina comparando com espermatozoides do grupo controle. Objetiva de 40X. 


\subsection{Parâmetros hematológicos}

As avaliações do perfil hematológico demonstraram que os valores das médias das Hemácias (x106/ $\mathrm{L}$ ) variaram entre 15,38 a 19,05, médias dos Hematócritos (\%) variaram entre 48,32 a 57,03 e médias de leucócitos totais $(/ \mu \mathrm{L})$ variaram entre 5.733 a 11.175 nos quatro grupos e as amostras de plaquetas apresentaram-se agregadas.

As análises dos dados realizadas revelaram que não houve diferença significativa nos valores de Leucócitos, Leucócitos totais, Hemácias, Hematócritos, Hemoglobina, Índices hematimétrico, Plaquetas, Neutrófilos Segmentados, Linfócitos e Monócitos nos quatro grupo de animais. Para cada parâmetro hematológico avaliado, os valores foram expressos em média e erro padrão, e os resultados da comparação destes por cada grupo de animais, serão demonstrados na tabela a seguir (Tabela 4), entretanto algumas amostras não foram processadas por estarem coaguladas. 
Tabela 4 - Parâmetros Hematológicos dos ratos Wistar expostos a diferentes concentrações de extrato aquoso de neem.

\begin{tabular}{|c|c|c|c|c|c|}
\hline Parâmetros & Unidade & \multicolumn{4}{|c|}{ GRUPO } \\
\cline { 2 - 6 } & & Controle (n=4) & $\mathbf{5 . 0 0 0} \mathbf{~ p p m ~ ( n = 4 )}$ & $\mathbf{7 . 5 0 0}$ ppm (n=5) & $\mathbf{1 0 . 0 0 0}$ ppm(n=3) \\
\hline Leucócitos totais & $/ \mu \mathrm{L}$ & $6,200 \pm 2132,3$ & $11,175 \pm 6743,1$ & $10,280 \pm 4916,5$ & $5,733 \pm 2867,6$ \\
\hline Hemácias & $\mathrm{x} 10^{6} / \mu \mathrm{L}$ & $15,38 \pm 3,25$ & $19,05 \pm 0,8347$ & $17,66 \pm 0,6877$ & $16,13 \pm 4,0501$ \\
\hline Hematócritos & $\%$ & $50,15 \pm 2,02$ & $57,03 \pm 2,04$ & $48,32 \pm 8,57$ & $47,97 \pm 11,48$ \\
\hline Hemoglobina & $\mathrm{g} / \mathrm{dL}$ & $15,55 \pm 1,69$ & $19,05 \pm 0,415$ & $17,54 \pm 0,273$ & $16,13 \pm 2,3410$ \\
\hline $\mathrm{VCM}$ & $\mathrm{fL}$ & $60,43 \pm 1,51$ & $60,6 \pm 0,8287$ & $61,36 \pm 1,21$ & $60,27 \pm 0,9866$ \\
\hline HCM & $\mathrm{Pg}$ & $20,03 \pm 0,7932$ & $20,18 \pm 0,1708$ & $20,8 \pm 0,6442$ & $20,33 \pm 1,02$ \\
\hline CHCM & $\%$ & $33,18 \pm 0,9394$ & $33,35 \pm 0,4796$ & $34,2 \pm 0,3162$ & $33,5 \pm 1,4$ \\
\hline Plaquetas & $/ \mu \mathrm{L}$ & $185,750 \pm 152,622$ & $922,750 \pm 595,549$ & $894,800 \pm 483,830$ & $468,333 \pm 670,343$ \\
\hline Neutrófilos Segmentados & $/ \mu \mathrm{L}$ & $846,5 \pm 657,08$ & $2140,75 \pm 1472,45$ & $1068 \pm 507,69$ & $651 \pm 456,21$ \\
\hline Linfócitos & $/ \mu \mathrm{L}$ & $6024,5 \pm 2624,10$ & $8740 \pm 4957,11$ & $8057,6 \pm 4624,23$ & $5224,33 \pm 2639,15$ \\
\hline Monócitos & $/ \mu \mathrm{L}$ & $150 \pm 139,23$ & $294,25 \pm 495,32$ & $262,2 \pm 284,87$ & $158,67 \pm 109,20$ \\
\hline
\end{tabular}

Fonte: (CARDOSO, C.A., 2018).

Nota: Valores expressos em média \pm erro padrão 


\subsection{Avaliações macro e microscópica dos órgãos alvo: Testículo, Fígado e Rins}

As avaliações macroscópicas dos órgão alvo: testículo, fígado e rins demonstraram que não houve nenhuma modificação morfológica e quando avaliamos os valores de massa úmida por análise estatística não foi encontrado diferença significativa nos valores (Tabela 5).

Com o procedimento de necropsia feito foi então realizada a avaliação macroscópica dos órgãos que não revelou nenhuma alteração significativa.

As análises revelaram que os testículos se apresentaram envoltos por uma cápsula de natureza conjuntiva, de cor branco-nacarada (túnica albugínea) e possuíam um formato redondo-ovalado, com eixo longo obliquo direcionado caudal e dorsalmente. Septos de tecido conjuntivo dividiam o testículo em lóbulos incompletos; nos lóbulos se encontravam os túbulos seminíferos que se esvaziavam dentro da rede de testículo no mediastino.

O fígado dos animais se apresentou relativamente volumoso de cor vermelho acastanhado, superfície lisa e dividido em lobos onde o direito se apresentou maior que o esquerdo. Não foi verificada característica friável e tampouco dilatação cavernosa dos sinusoides em áreas com perda de hepatócitos.

Os rins se mostraram lisos, unilobar e com formato de feijão com uma borda convexa e outra côncava na qual se situa o hilo, de onde entram e saem os vasos sanguíneos, nervos e ureter. Apresentou coloração marrom avermelhada e uma cobertura capsular de tecido conjuntivo denso.

Tabela 5: - Valores de massa úmida dos órgãos alvo, em gramas, de ratos Wistar expostos a diferentes concentrações de extrato aquoso de Neem.

\begin{tabular}{|c|c|c|c|c|}
\hline \multirow{2}{*}{$\begin{array}{c}\text { Massa úmida } \\
\text { (gramas) }\end{array}$} & Controle & $\mathbf{5 . 0 0 0} \mathbf{~ p p m}$ & $\mathbf{7 . 5 0 0} \mathbf{~ p p m}$ & $\mathbf{1 0 . 0 0 0 p p m}$ \\
\hline Testículo & $1,65 \pm 0,11$ & $1,61 \pm 0,16$ & $1,65 \pm 0,21$ & $1,73 \pm 0,16$ \\
\hline Fígado & $9,52 \pm 0,72$ & $10,22 \pm 1,36$ & $10,58 \pm 1,59$ & $10,42 \pm 1,54$ \\
\hline Rim & $1,83 \pm 0,09$ & $1,80 \pm 0,10$ & $2,05 \pm 0,21$ & $1,98 \pm 0,07$ \\
\hline
\end{tabular}

Fonte: (CARDOSO, C.A., 2018).

Nota: Valores expressos em média \pm erro padrão 
A análise histológica dos testículos dos animais dos quatro grupos demonstram que estes apresentavam uma citoarquitetura normal. Os testículos apresentando-se compostos pelo parênquima testicular e por numerosos túbulos seminíferos dispostos no compartimento tubular. $\mathrm{Na}$ membrana basal encontramos as células de Sertoli, espermatogônias - células pequenas com núcleo escuro e arredondado e espermatócitos - células maiores com cromatina bem distinta e núcleo grande (Figura 7 A, D, G e J).

O epitélio germinativo apresenta-se composto por células da linhagem espermatogênica em diferentes estágios meiótico, localizadas entre a membrana basal e o lúmen tubular, a análise também nos permitiu visualizar a presença de espermatozoides em todos os grupos estudados (Figura 7 A, D, G e J)

Os resultados dos fígados revelaram que todos os animais pertencentes aos quatro grupos avaliados apresentaram citoarqueitetura normais, hepatócitos dispostos nos lóbulos hepáticos arranjados de modo a formar placas celulares direcionadas da periferia dos lóbulos para centro, e entre essas placas observase os sinusóides. Os hepatócitos apresentaram morfologia normal, sem a presença de infiltrado de linfócitos, marcas de necrose ou congestão dos sinusoides (Figura 7 B, E, H e K).

A análise dos rins destacaram que a citoarquitetura lobular estava preservada, com pirâmides medulares recobertas por tecido cortical. O córtex renal apresentou glomérulos regularmente distribuídos, cápsula Bowman fina e espaço urinário preservado e o epitélio glomerular se apresentou de forma arredondada (Figura $7 \mathrm{C}, \mathrm{F}, \mathrm{I}$ e L).

Nenhuma das alterações pesquisadas foram reveladas nem no fígado nem nos rins. 
Figura 7 - Histologia dos órgãos alvo: testículo, fígados e rim de ratos Wistar expostos a diferentes concentrações de extrato aquoso de neem.
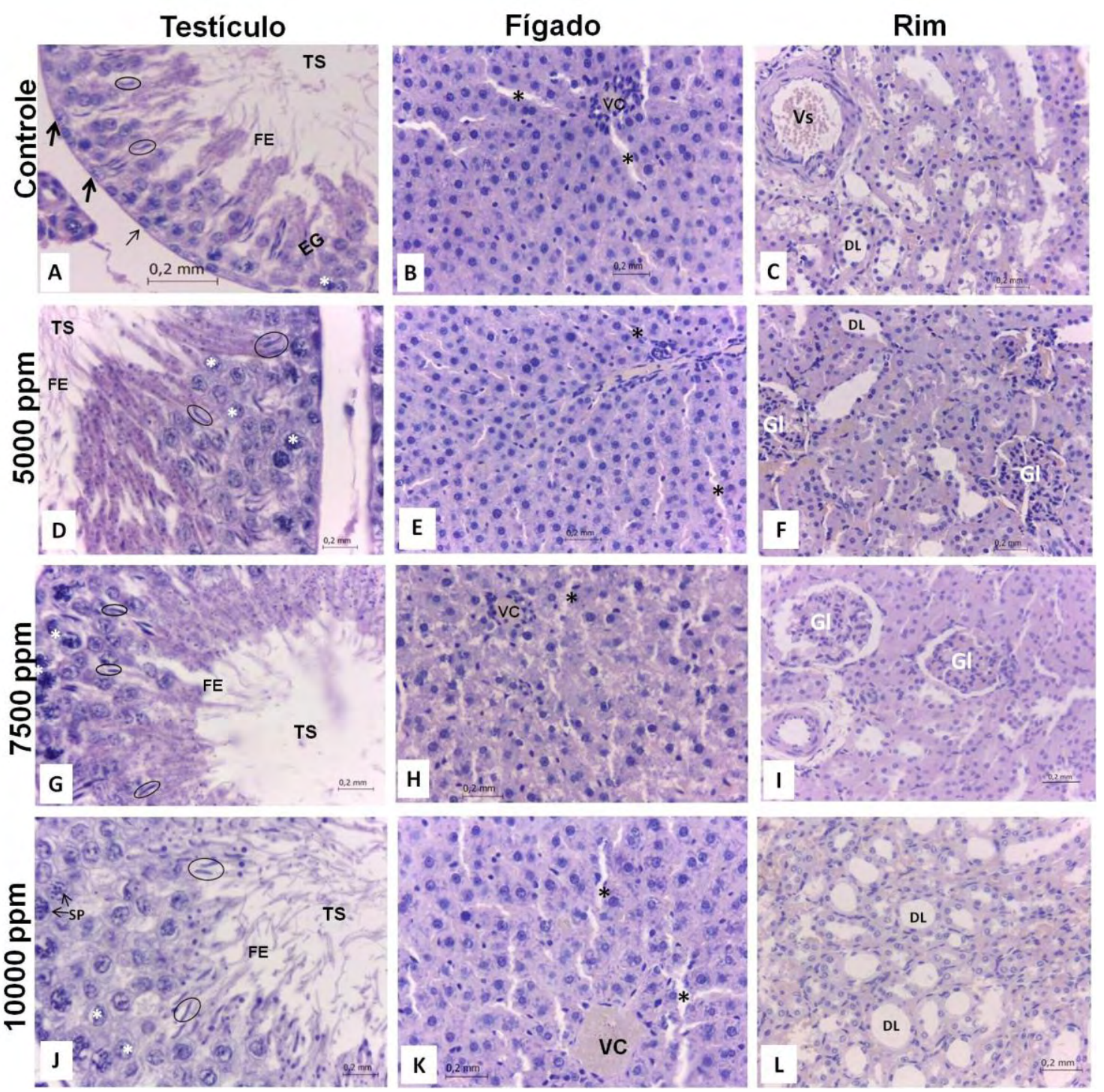

Fonte: (CARDOSO, C.A., 2018).

Legenda: Fotomicrografias dos órgão: testículos, fígado e rim de ratos Wistar. Em $\mathbf{A}, \mathbf{D}$, G e $\mathbf{J}$ evidenciamos as estruturas controle e em B-C, E-F, H-I e K-L destacamos os TECIDOS expostos a concentrações de 5000, 7500 e 10000ppm de extrato aquoso de neem respectivamente. Nos testículos destacamos no epitélio germinativo (EG) do túbulo seminífero (TS) as Espermatogônias (Seta fina), Espermatócitos (*), Células de Sertoli (seta grossa), Cabeça do espermatozoide (circulo) e Flagelo do espermatozoide (FE). Nas fotomigrografias dos fígados demostramos a presença do sinusóides hepáticos $\left(^{*}\right)$ e da veia centro lobular (VC) e nos rins apontamos a presença dos ductos coletores (DL), Glomérulo (GL) e vaso sanguíneo (Vs). Coloração H/E. 
8. DISCUSSÃO

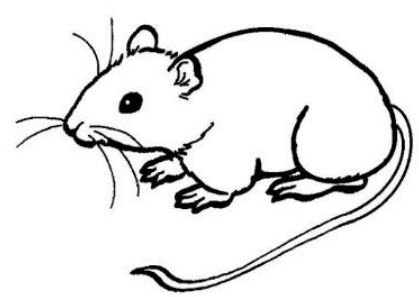




\section{DISCUSSÃO}

Este presente trabalho teve como propósito avaliar a propriedade terapêutica contraceptiva em machos de ratos Wistar e a toxicidade do extrato aquoso das folhas do Neem (Azadirachta indica- Meliaceae) originário da Índia e adaptado no Brasil, uma vez que a planta produz seus metabolitos secundários totalmente influenciada pelo ambiente no qual ela está inserida, e os trabalhos com mesma base cientifica utilizam-se geralmente da planta indiana ou oriunda do continente africano para estudo (CHATTOPADHYAY e BANDYOPADHYAY, 2005; NACIF DE ABREU e MAZZAFERA, 2005; ATAWODI e ATAWODI, 2009; SCHUMACHER, et al., 2011 ; OFEM, IKPI e ESSIEN, 2013; ABDEL MONEIM, 2014; RAJEI, et al., 2015; SATYANARAYANA, et al., 2015; BHAJONI , MESHRAM e LAHKAR, 2016; KANDHARE, MUKHERJEE e BODHANKAR, 2017; KATTE, RAJYALAKSHMI e ALADAKATTI, 2018).

Nossos resultados corroboraram com Silva (2010), que administraram via oral três doses de $1 \mathrm{~mL}, 2 \mathrm{~mL}$ e $3 \mathrm{~mL}$ em três concentrações (50, 100 e $200 \mathrm{mg} / \mathrm{kg}$ ) de extrato etanólico de Neem em ratas Wistar prenhas, e nenhum sinal clínico de toxicidade pode ser observado, nem tampouco houve alteração ou prejuízo no ganho de peso, assim também verificado na presente pesquisa.

Nossos achados entretanto diferem de Gbotolorun, et al., (2008) que observaram redução de 6,46\% na massa corporal de ratas Wistar que receberam por via oral com $1 \mathrm{mg} / \mathrm{kg}$ do extrato etanólico das flores de Neem por 5 dias, devido a uma diarreia intensa. Em nosso estudo, alguns animais após a administração da primeira dose apresentaram um quadro de diarreia muito discreto que cessou rapidamente.

Quando avaliamos o consumo de ração podemos afirmar que não houve diferença nos grupos testados, assim como descrito por Pires Junior (2010), que administraram extrato hexânico de frutos $M$. azedarach (Meliaceae) sobre ratos Wistar (machos e fêmeas) na dose $300 \mathrm{mg} / \mathrm{kg}$ e $2000 \mathrm{mg} / \mathrm{kg}$ por 14 dias. Contudo contrário a nossos resultados, os camundongos Swiss machos com a dose de $2000 \mathrm{mg} / \mathrm{kg}$, apresentaram menor consumo de ração em relação ao grupo controle avaliado. 
Em relação ao consumo de água encontramos que foi maior nos grupos tratados entretanto quando aplicamos análise estatística não foi revelada diferença significativa, contrariando o encontrado no estudo de Pires Junior (2010), no qual a ingestão hídrica foi maior nos grupos controle de machos de camundongos com menor dose (300 mg/kg) e ratos; com exceção dos camundongos Swiss machos tratados com a dose de $2000 \mathrm{mg} / \mathrm{kg}$ que corrobora com nossos resultados.

Segundo Laudano (2005) e Gonçalves (2007) plantas da família Meliaceae tem sido bastante estudadas pela sua importância medicinal, fitoquímica e no controle de insetos. O chá das folhas e cascas da espécie Cedrela odorata (cedro) por exemplo, apresenta comprovado poder febrífugo, mantendo a temperatura corpórea em níveis considerados normais, fato observado no em nosso trabalho. Spalutto Fontes e Santos (2013), apresentaram em seu trabalho que a temperatura média de um rato Wistar adulto macho considerada normal está entre $36-37,5^{\circ} \mathrm{C}$.

A avaliação hematologica mostrou que não houve alteração dos parâmetros, assim como descrito por Coelho (2014) em ovinos da raça Laucane gestantes e não gestantes, o qual administrou Neem por 126 dias sob a forma de torta composta apenas de resíduos de sementes provenientes da extração do óleo nas concentrações de 1,2\% e 4\% adicionado ao sal mineral. Contudo, Lipinski et al. (2011), em um estudo realizado com búfalos, utilizando a associação de torta de Neem e alho desidratado oferecido aos animais por um período de 6 meses observaram a redução do hematócrito após o tratamento, porém este permaneceu dentro dos valores de referência.

Em nosso trabalho foi constatado efeito dose resposta após oito dias de administração do extrato aquoso de Neem por via oral na qualidade reprodutiva dos animais, mesmo fato verificado por Auta e Hassan (2015) em sua pesquisa, onde o extrato aquoso feito a partir das cinzas da madeira de Neem oriundo da Nigéria, provocou a diminuição significativa da motilidade espermática, e na contagem de espermatozóides vivos de ratos Wistar tratados via oral por 35 dias.

Corroborando com os presentes resultados, os dados apresentados por Aladakatti, et al., (2001) acerca de estudo com tratamento de Azadirachta indica por 48 dias em ratos albinos via gavagem, demonstraram a diminuição da contagem total, na motilidade e velocidade dos espermatozoides. 
Os estudos de Khillare e Shrivastav (2001) avaliaram in vitro o efeito do extrato das folhas de Neem em várias concentrações sobre a motilidade e viabilidade de espermatozoides humanos, demonstrando a eficácia do mesmo no sentido de deixá-los completamente imóveis. A viabilidade dos mesmos foi totalmente inibida, similar ao encontrado no presente trabalho nas doses 7.500 ppm e 10.000 ppm que pode ser verificado no presente trabalho se observando os espermatozoides que foram corados pela Eosina.

A administração via oral do extrato aquoso de Neem por 28 dias em camundongos causaram uma desordem no epitélio germinativo do túbulo seminífero tendo sua histoarquitetura afetada, sendo revelado nestes casos soltura do epitélio germinativo, condensação marginal da cromatina em espermátides arredondadas, ocorrência de células gigantes, mistura de tipos de células germinativas nos estágios diferentes da espermatogênese e degeneração em células germinativas (MISHRA e SINGH, 2005), resultados estes que não atestam nossos achados, onde os testículos dos animais dos quatro grupos avaliados apresentaram citoarquitetura normal. Os túbulos seminíferos se apresentaram envoltos por uma lâmia basal, apresentaram epitélio germinativo normal e constituído de várias camadas de células germinativas em diferentes estágios de desenvolvimento e espermatozoides no lúmen, todos estes com morfologia normal, bem como descrito por Ojewale, et al., (2014) em extrato etanólico das raízes de Pseudocedrela kotschyi, em camundongos Swiss macho com diabetes induzida por Alloxan.

Segundo Costa e Rego de Paula (2003) a duração do ciclo do epitélio seminífero é geralmente constante para uma determinada espécie, variando no entanto de uma espécie para a outra. Este intervalo de tempo dura para ratos 12,9 dias. Considerando o tempo de oito dias de administração do extrato aquoso de Neem no presente estudo e também a duração do ciclo do epitélio seminífero em ratos não é pertinente implicar que tais fatos possam afetar a acurácia dos resultados observados. Segundo Lisanti, et al., (2016) o desenvolvimento de motilidade, a transformação das estruturas da cauda dos espermatozóides, a alteração morfológica do acrossomo, o desaparecimento da gotícula citoplasmática e a transformação da membrana plasmática ocorrem no processo de maturação espermática no epidídimo e não no testículo no decorrer do ciclo. Logo o déficit na motilidade e viabilidade dos espermatozoides 
observadas neste estudo foram, muito provavelmente, em decorrência a eventos ocorridos no epidídimo e não no testículo.

Gwayi e Bernard, (2002) destacaram que valores de pH na motilidade e qualidade de espermatozoides de rato Wistar seria $\mathrm{pH} 7,6$, sendo tal valor muito próximo do encontrado no presente trabalho quando verificado $\mathrm{pH}$ por fita $7,2 \mathrm{a}$ 7,8 .

Silveira-Barbetti, (2008), fazendo um estudo com amostras seminal humanas encontrou viscosidade normal quando a saída do sêmen ocorresse em gotas individuais (sem formação de filamento), o mesmo ocorreu no presente trabalho, onde não houve a formação de filamento seminal; as amostras de sêmen normal apresentaram-se brancas, opalescentes e homogêneas. Tanto os valores de $\mathrm{pH}$ quanto a cor seminal concordaram com nossos resultados.

Contrários aos nossos achados Sathiyaraj, e colaboradores (2010), relataram que houve diminuição significativa nos pesos dos testículos, quando administrado aos ratos Wistar o extrato aquoso de folha de Neem, durante um período de 30 dias, via oral, neste caso a contrariedade em relação aos nossos resultados pode ter ocorrido por conta do tempo de administração do extrato.

Ashafa, Orekoya e Yakubu, (2012) para investigarem as implicações tóxicas do extrato da casca do caule etanólico de Azadirachta indica (Neem) em ratos Wistar, via oral por 21 dias realizaram um estudo morfológico em fígado e rins, e constataram aumento no peso dos fígados dos animais relacionados ao aumento da dose do extrato, revelando uma relação dose dependente; já diferentemente em relação ao peso dos rins não houve uma variação significativa nos pesos dos órgãos quando comparados ao grupo controle. Contudo em nossa pesquisa o peso dos fígados se manteve sem alteração significativa entre os grupos analisados, acontecendo diferença numérica no peso dos rins quando considerados os grupos controle e grupo10.000 ppm.

Pires Junior, et al., (2012), quando analisaram os efeitos do extrato hexânico de frutos de Melia azedarach (MELIACEAE), dose única, administrado via oral na concentrações de $300 \mathrm{mg} / \mathrm{kg}$ e $2000 \mathrm{mg} / \mathrm{kg}$ em camundongos machos e fêmeas Swiss, não encontraram alterações macroscópica ou microscópica no fígado e rins dos mesmos, assim como os animais pertencentes aos quatro grupo avaliados em nosso estudo. Também em concordância com nossos resultados, estudando os mesmos órgãos, Pessoa (2009), obteve ao tratar ratas 
Wistar com produto piolhicida a base de extrato concentrado contendo Azadirachta indica L., (1\%) Carapa guianensis Aublet (3\%) e Saccharum officinarum L. (20\%), por 15 dias.

Lisanti, et al., (2018) ao administrar o extrato aquoso das sementes de Neem para camundongos machos via oral por 36 dias nas doses 0,25 e 0,50 $\mathrm{mg} / \mathrm{kg}$, e realizar análise histopatológica 36 dias após cessado o tratamento pode verificar degeneração nos hepatócitos, fato este que não foi observado no presente trabalho, onde os hepatócitos apresentaram citoarquitetura totalmente integra e preservada. Pode-se considerar que o tempo continuo de tratamento pode ter contribuído para tal achado nos camundongos tratados por 36 dias.

Glinsukon, et al., (1986) administraram dose única de Nimbolida, tetrapernóide constituinte químico importante das folhas de Neem, $-500 \mathrm{mg} / \mathrm{kg}$, e ácido nimbico diluídos em DMSO, para camundongos Swiss machos e fêmeas, ratos Fischer machos e hamsters dourados machos via oral por gavagem. Ao realizar análise histopatológica os autores puderam notar que os rins dos camundongos e hamsters apresentaram necrose tubular, onde as células tubulares apresentavam processos necróticos com núcleos picnóticos, conteúdo citoplasmático desestruturado, restos celulares e descamação; enquanto que no fígado dos hamsters foram reveladas infiltração gordurosa e necrose. 
9. CONSIDERAÇÕES FINAIS

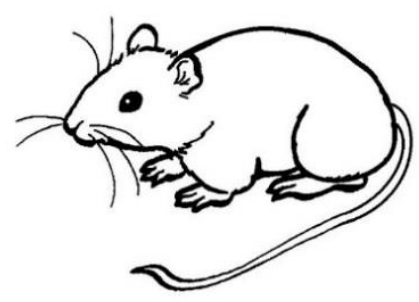




\section{CONSIDERAÇÕES FINAIS}

Neste presente trabalho verificou-se que extrato aquoso de Neem administrado por oito dias, via oral, nas concentrações 5.000 ppm, 7.500 ppm e 10.000 ppm parece não ter influência no aparecimento de sinais clínicos de toxicidade nos animais, pois não causou alterações fisiológicas.

Não houve alteração da cor, $\mathrm{pH}$ ou viscosidade seminal, nem tampouco alterações macro e microscópicas dos órgãos fígado, rins e testículos. Contudo um discreto aumento no peso da massa úmida nos rins foi observado fato este que pode ser considerado em estudos futuros.

Ressaltamos que o extrato aquoso de Neem na dose de 10.000 ppm influência a capacidade reprodutiva dos animais, uma vez que observamos alteração na motilidade e na viabilidade dos espermatozoides, sugerindo assim uma ação contraceptiva do extrato aquoso de Neem. 
10.SUGESTÕES PARA TRABALHOS FUTUROS

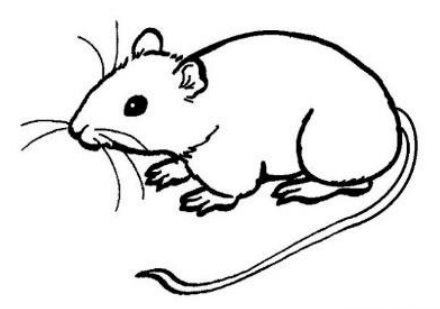




\section{SUGESTÕES PARA TRABALHOS FUTUROS}

Após análise de nossos achados sugerimos que haja a caracterização do extrato aquoso das folhas de Neem produzido com material de plantas adaptadas no Brasil, e em outra etapa a indução de cópula utilizando os machos após findado o tratamento, a fim de verificar a possível reversibilidade da ação contraceptiva do composto. 
11. REFERÊNCIAS

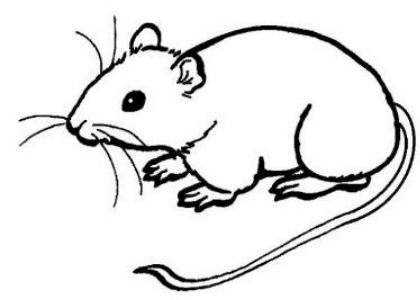




\section{REFERÊNCIAS}

ABDEI, M. A. E. Azadirachta indica attenuates cisplatin-induced neurotoxicity in rats. Indian Journal of Pharmacology, v. 46, n. 3, p. 316-321. 2014. Disponível em: <https://www.ncbi.nlm.nih.gov/pmc/articles/PMC4071710/ >. Acesso em: 25/08/2018.

ALBERTS, B.; et al. Citoesqueleto. In: São Paulo: Artmed, 2011. Cap. 17, p. $\overline{573-608}$

Fundamentos da Biologia Celular.

ANDRADE SANTOS, A.F. Avaliação toxicológica da ayahuasca em ratos wistar: comportamento e toxicidade reprodutiva em machos. 2016. Dissertação (Mestrado em Ciências da Saúde) - Programa de Pós-Graduação em Ciências da Saúde, da Universidade de Brasília. Brasília. 2016. Disponível em: < http://www.toxicologia.unb.br/admin/ckeditor/kcfinder/upload/files/Disserta\%C3\%A7 \%C3\%A30\%20final\%20alana.pdf >. Acesso em: 18/01/2018.

ANJAMROOZ, S.H., et al. Assessment of morphological and functional changes in the mouse testis and epididymal sperms following busulfan treatment. Iranian Biomedical Journal. v. 11 n.1, p. 15-22 .2007.

ALADAKATTI, R.H., et al. Sperm parameters changes induced by Azadirachta indica in albino rats. Journal of Basic and Clinical Physiology and

Pharmacology. v. 12, n.1. p. 79-86. 2001. Disponível em: < https://www.degruyter.com/view/j/jbcpp.2001.12.1/jbcpp.2001.12.1.69/jbcpp.2001.1 2.1.69.xml>. Acesso em 12/09/2018.

ALBUQUERQUE, M.B., et al. Efeito do extrato aquoso das folhas de nim indiano (Azadirachta indica) sobre o crescimento inicial de plantas daninhas. Gaia Scientia. v. 9, n.1, p.1-6. 2015. Disponível em: <periodicos.ufpb.br/index.php/gaia/article/download/19211/13186>. Acesso em 20/08/2018.

ALVAREZ, C.A., et al. Efeito da suplementação de selenometionina e vitamina C sobre as características quantitativas e qualitativas do sêmen de coelho. Acta Sci. Anim. Sci. v. 28, n. 2, p. 177-185. 2006. Disponível em :< http://www.redalyc.org/html/3031/303126481004/>. Acesso em 21/05/2018.

ANDREAZZI, M.A., et al. Avaliação da qualidade do sêmen em coelhos alimentados com rações contendo diferentes fontes de óleos vegetais. Acta Scientiarum. Animal Sciences. v. 26, no. 1, p. 87-93, 2004. Disponível em: < http://ojs.uem.br/ojs/index.php/ActaSciAnimSci/article/view/1945/1217>. Acesso em 12/09/2018.

AGÊNCIA NACIONAL DE VIGILÂNCIA SANITÁRIA (ANVISA). Guia para a condução de estudos não clínicos de toxicologia e segurança farmacológica necessários ao desenvolvimento de medicamentos - Gerência de Avaliação de Segurança e Eficácia - GESEF. Brasília: DF. ANVISA.2013. Disponível em:< http://portal.anvisa.gov.br/documents/33836/2492465/Guia+para+a+Condu\%C3\%A $7 \% \mathrm{C} 3 \% \mathrm{~A} 30+\mathrm{de}+\mathrm{Estudos}+\mathrm{N} \% \mathrm{C} 3 \% \mathrm{~A} 30+\mathrm{Cl} \% \mathrm{C} 3 \% \mathrm{ADnicos}+\mathrm{de}+$ Toxicologia $+\mathrm{e}+\mathrm{Seg}$ uran\%C3\%A7a+Farmacol\%C3\%B3gica+Necess\%C3\%A1 rios+ao+Desenvolviment o+de+Medicamentos+-+Vers\%C3\%A3o+2/a8cad67c-14c8-4722-bf0f-

058a3a284f75>.Acesso em:20/06/2017. 
AGÊNCIA NACIONAL DE VIGILÂNCIA SANITÁRIA (ANVISA). Relatório das análises de amostras monitoradas no período de 2013 a 2015. Brasília: DF. ANVISA, 2016.Disponível em: < http://portal.anvisa.gov.br/documents/111215/0/Relat\%C3\%B3rio+PARA+20132015_VERS\%C3\%83O-FINAL.pdf/494cd7c5-5408-4e6a-b0e5-5098cbf759f8>. Acesso em: 11/07/2017.

AKBARSHA, M. A.; MURUGAIAN, P. Aspects of the male reproductive toxicity/male antifertility property of andrographolide in albino rats: effect on the testis and the cauda epididymidal spermatozoa. Phytotherapy Research, v.14, n. 6, p. 432-435. 2000.

ARCURI, G.B. Efeitos do estresse no manejo reprodutivo em cães machos de trabalho militar. 2015. Dissertação. 58 f. (Mestrado em Ciências). Programa de Pós-Graduação em Biociência Animal, da Faculdade de Zootecnia e Engenharia de Alimentos da Universidade de São Paulo. Pirassununga. 2015. Disponível em: < http://www.teses.usp.br/teses/disponiveis/74/74135/tde-04022016-111036/ptbr.php>. Acesso em: 29/01/2018.

ASHAFA, A. O. T., OREKOYA, L. O., YAKUBU, M. T. Toxicity profile of ethanolic extract of Azadirachta indica stem bark in male Wistar rats. Asian Pacific Journal of Tropical Biomedicine, v. 2, n. 10, p.811-817. 2012.

AUTA, T.; HASSAN, A.T. Reproductive toxicity of aqueous wood-ash extract of Azadirachta indica (neem) on male albino mice. Asian Pacific Journal of Reproduction. v. 5, n.2, p. 111 - 115. 2015. Disponível em: < http://dx.doi.org/10.1016/j.apjr.2016.01.005>. Acesso em 20/08/2018

ATAWODI; S.E.; ATAWODI, J.C. Azadirachta indica (neem): a plant of multiple biological and pharmacological activities. Phytochemistry Reviews .v. 8, n. 3, p. 601-620. 2009. Disponível em: <https://doi.org/10.1007/s11101-009-9144-6 >. Acesso em 23/06/2018.

BACHA, JR. ; BACHA, L.M. Sistema Digestório . In: Atlas Colorido de Histologia Veterinária. São Paulo: Rocca, 2003. Cap.13, p. 195 - 273.

BACHA, JR. ; BACHA, L.M. Sistema Urinário. In: Atlas Colorido de

Histologia Veterinária. São Paulo: Rocca, 2003. Cap.17, p. $275-292$.

BACHA, JR.; BACHA, L.M. Sistema Reprodutor Masculino. In: Atlas Colorido de Histologia Veterinária. São Paulo: Rocca, 2003. Cap.17, p. 335 353.

BANDIERA, S. Alterações hepáticas e renais em ratos expostos ao álcool, fumaça de cigarro ou sua associação. 2015. 62 f. Dissertação. (Mestrado). Programa de Pós-Graduação em Ciências Biológicas: Fisiologia, da Universidade Federal do Rio Grande do Sul. Porto Alegre. 2015. Disponível em: <http://www.lume.ufrgs.br/bitstream/handle/10183/114668/000955034.pdf?sequenc $\mathrm{e}=1$ >. Acesso em: 30/01/2018.

BARBOSA ROBERTO, J.V. et al. Parâmetros bioquímicos de referência de ratos wistar de diferentes faixas de peso, provenientes do biotério das faculdades Nova Esperança - PB. Revista de Ciências da Saúde Nova Esperança. v.16, n.1, p. 17. 2018. Disponível em: < www.facene.com.br/.../10.-PARÂMETROSBIOQUÍMICOS-DE-REFERENNCIA-DE-R>. Acessado em 18/8/2018.

BHAJONI P.S., MESHRAM G.G.' LAHKAR M. Evaluation of the Antiulcer Activity of the Leaves of Azadirachta indica: An Experimental Study. Integrative Medicine 
International. v. 3, n. 1-2, p. 10-16. 2016. Disponível em:

<https://www.karger.com/Article/Abstract/442750\#>. Acesso em 20/07/2018

BARROS BRASIL, R. Aspectos botânicos, usos tradicionais e potencialidades de Azadirachta indica (NEEN). Enciclopédia Biosfera. v. 5, n. 23, p. 1 - 17. 2013. Disponível em: < http://conhecer.org.br/enciclop/2013b/MULTIDISCIPLINAR/Aspectos.pdf> Acesso em 09/01/2019.

BÉLO, M. et al. Avaliação do efeito bioinseticida dos extratos de Tabernaemontana catharinensis A.DC. (Apocynaceae) e Zeyheria montana Mart. (Bignoniaceae) sobre a mosca Zaprionus indianus (Díptera: Drosophilidae) (Gupta, 1970). R. bras. Bioci., Porto Alegre, v. 7, n. 3, p. 235-239. 2009

BEZERRA, J.C. Efeito do extrato de Ginkgo biloba, após exposição materna, sobre os testículos e epidídimo de ratos Wistar. 2015. 56 f. Dissertação (Mestrado em Saúde) -Programa de Pós-graduação em Saúde Brasileira, da Universidade Federal de Juiz de Fora. Juiz de Fora. 2015.Disponível em: < https://repositorio.ufjf.br/jspui/bitstream/ufjf/4563/1/jessicacorreabezerra.pdf>. Acessado em 21/01/2018

BEZERRA, D. G.; F.M., CARNEIRO; MARCIANO DE PAULA, J. A. II Congresso de Ensino, Pesquisa e Extensão da UEG. 2. 2015. Meta-análise do impacto ambiental de inseticidas naturais e químicos no meio ambiente. Anais. Campus Pirenópolis. Goiás: UEG. 2015. Disponível em:

<http://www.anais.ueg.br/index.php/cepe/article/viewFile/5877/3652>. Acesso em 26/07/2018.

BRASIL. Ministério da Saúde. Secretaria de Atenção à Saúde. Instituto Nacional de Câncer. Coordenação de Prevenção e Vigilância. Vigilância do câncer ocupacional e ambiental. Rio de Janeiro: INCA, 2005. 64p. Disponível em: < http://www.inca.gov.br/inca/Arquivos/publicacoes/vigilanciadocancerocupacional.pd f>. Acesso em: 20/01/2017.

BOEKE, S.J.; et al. Safety evaluation of neem (Azadirachta indica) derived pesticides. Journal of Ethnopharmacology. v. 94 , p.25-41. 2004. Disponível em: < https://www.sciencedirect.com/science/article/pii/S0378874104002491>. Acesso em 12/09/2018.

BROLESE, G. Marcadores de desenvolvimento em filhotes de ratas expostas ao álcool no período pré -natal. 2009. 104 f. Dissertação (Mestrado em neurociências) - Programa de Pós-graduação em Neurociências, Instituto de Ciências da Saúde da Universidade Federal do Rio Grande do Sul. Porto Alegre. 2009. Disponível em: <

https://www.lume.ufrgs.br/bitstream/handle/10183/24401/000746813.pdf?sequence $=1>$. Acessado em 18/01/2018.

BRUNHEROTTO, R.; VENDRAMIM, J.D. Bioatividade de Extratos Aquosos de Melia azedarach L. Sobre o Desenvolvimento de Tuta absoluta (Meyrick) (Lepidoptera: Gelechiidae) em Tomateiro. Neotropical Entomology. v. 30 n.3, p. 455-459. 2001

BUENO, R.T., et al. Avaliação dos efeitos do extrato aquoso de Turnera diffusa na histologia testicular e ovariana e nos parâmetros reprodutivos de ratos Wistar.

Biosaúde, Londrina, v. 11, n. 1, p. 29-42. 2009. 
CARVALHO, G.D. et al. Avaliação clínica de ratos de laboratório (Rattus novergicus linhagem Wistar): parâmetros sanitários, biológicos e fisiológicos. Revista Ceres, vol. 56, n. 1, p. 051-057, 2009.

CHAUDHARY, S., et al. Progress on Azadirachta indica Based Biopesticides in Replacing Synthetic Toxic Pesticides. Frontiers in Plant Science. v. 8, n.610, p. 113. 2017. Disponível em: <http://doi.org/10.3389/fpls.2017.00610>. Acesso em 17/08/2018.

CHATTOPADHYAY, R.R.; BANDYOPADHYAY, M. Possible mechanism of hepatoprotective activity of Azadirachta indica leaf extract against paracetamolinduced hepatic damage in rats: Part III. Indian Journal Pharmacology. v.37, n. 3, p. 184 - 185. 2005. Disponível em: < http://www.ijponline.com/text.asp?2005/37/3/184/16218 >. Acesso em 18/08/2018.

CHIEREGATTO, L.C. Efeito do tratamento crǒnico com extratos de Heteropterys aphrodisiaca O. Mach e Anemopaegma arvense (Vell.) Stellf no testículo de ratos wistar adultos. 2005. $81 \mathrm{f}$. Dissertação (Mestrado em Medicina Veterinária) - Viçosa: Universidade Federal de Viçosa. 2005. Disponível em: $<$ http://www.locus.ufv.br/bitstream/handle/123456789/5020/texto\%20completo.pdf?s equence $=1>$. Acesso em 12/10/2018.

COELHO, M. M. Avaliação hematológica e hepática de ovinos sob tratamento com torta de Neem (Azadirachta indica). 2014. 82 f. Dissertação (Mestrado em Ciência Animal) - Universidade do Estado de Santa Catarina. Programa de PósGraduação em Ciência Animal, Lages, 2014.

COSTA, D.S.; REGO DE PAULA, T.A. Espermatogênese em mamíferos. Scientia Vila Velha (ES), v. 4, n. 1/2, p. 53-72, 2003. Disponível em: < https://www.researchgate.net/publication/294693135 Espermatogenese em mami feros $>$. Acesso em: 10/01/2019.

CUNHA, L. C. Avaliação dos efeitos tóxicos da Mascagnia rigida em ratos. Estudo anatomopatológico. Comparação entre metodologias cromatográficas para detecção do fluoroacetato de sódio. 2008. $101 \mathrm{f}$. Dissertação (Mestrado em Patologia Experimental e Comparada) - Faculdade de Medicina Veterinária e Zootecnia, São Paulo, 2008. Disponível em:< http://www.teses.usp.br/teses/disponiveis/10/10133/tde-28052008100702/en.php>. Acesso em: 12/09/2018.

DAROLT, M.R. Comparação entre a qualidade do alimento orgânico e convencional In: STRIGHETA, P.C.; MUNIZ, J.N. Alimentos Orgânicos: Produção, Tecnologia e Certificação. 1 ed.Viçosa: Universidade Federal de Viçosa - UFV, 2003, p.289-312. Disponível em: <

http://www.iapar.br/arquivos/File/zip_pdf/OrgConvenc.pdf>. Acesso em 11/10/2018.

DEHGHAN, M.H.; MARTIN, T.; DEHGHANAN, R. Antifertility effect of Iranian neem seed alcoholic extract on epididymal sperm of mice. Iranian Journal of Reproductive Medicine. v.3., n.2, p. 83-89, 2005.

ERDMANN, R.H., et al. Exame reprodutivo em gato-do-mato-pequeno (Leopardus tigrinus Schreber, 1775). Archives of Veterinary Science. v. 10, n. 2, p. 75-79, 2005 
FARIA SALVIANO, M. Análise fisiológica e comportamental de modelos animais desenvolvidos geneticamente para o estudo da ansiedade e da Doença de Alzheimer. 2013. 158 f. Tese (Doutorado em Ciências do Comportamento - Área de Cognição e Neurociências do Comportamento). PósGraduação em Ciências do Comportamento da Universidade de Brasília. Brasília. 2013. Disponível em:

<http://www.repositorio.unb.br/bitstream/10482/13265/1/2013_MarcelodeFariaSalvi ano.pdf>. Acessado em: 18/01/2018.

GARCIA, et al. Ocorrência de artrópodes em lavoura de milho (Zea mays) no município de Arvoredo, SC. Bioikos / PUC - Campinas. v. 18, n.1, p. 21-28. 2004. Disponiível em: <http://periodicos.puc-

campinas.edu.br/seer/index.php/bioikos/article/view/874>. Acesso em: 11/10/2018.

GIANNOTTI, O. Resíduos de defensivos agrícolas nos alimentos. Revista do Serviço Público. v. 40, n.4, p. 177 - 185. 1983. Disponível em :< https://revista.enap.gov.br/index.php/RSP/article/view/2164/1095>. Acesso em $11 / 10 / 2018$.

GLINA, S.; VIEIRA, M. Cap. 2- Aspectos básicos do espermograma. In: MANU Manual de Urologia da Sociedade Brasileira de Urologia. São Paulo - S.P. p. 29 - 31. Disponível em: < http://www.ibb.unesp.br/Home/Departamentos/Morfologia/espermograma.pdf>. Acesso em 22/01/2018.

GOBBO-NETO, L.; LOPES, N.P. Plantas medicinais: fatores de influência no conteúdo de metabólitos secundários. Quim. Nova. v. 30, n. 2, 374-381, 2007.

GBOTOLORUN S.C.; et al. Antifertility potential of Neem flower extract on adult female Sprague-Dawley rats. Afr .Health Sci. v.8, n.3 . p. 168-173. 2008.

GOUSSAIN, M. M.; et al. Efeito da aplicação de silício em plantas de milho no desenvolvimento biológico da lagarta-do-cartucho Spodoptera frugiperda

(J.E.Smith) (Lepidoptera: Noctuidae). Neotropical Entomology . v. 31, n. 2. p. 305 - 310. 2002. Disponível em: < http://agris.fao.org/agris-

search/search.do? recordID=XS2002J00219 >. Acesso em 10/10/2018.

GONÇALVES, A.L. Estudo da atividade antimicrobiana de algumas árvores medicinais nativas com potencial de conservação/recuperação de florestas tropicais. 2007. 209f. Tese (doutorado) - Universidade Estadual Paulista, Rio Claro, 2007. Disponível em: < https://repositorio.unesp.br/bitstream/handle/11449/103944/goncalves_al_dr_rcla.p df? sequence $=1$ \&isAllowed $=y>$. Acesso em 09/01/2019.

GOMES, M.L.M. Morfometria testicular de ratos Wistar adultos tratados com infusão aquosa de catuaba (Trichilia catigua A. Juss. Meliaceae). 2007. 49f. Dissertação (Mestrado em Biologia Celular e Estrutural) - Universidade Federal de Viçosa, Viçosa, 2007. Disponível em: < http://www.locus.ufv.br/handle/123456789/2375>. Acesso em: 12/10/2018

GROCHANKE, B.S.; et al. Compostos fenólicos da casca de Handroanthus heptaphyllus (Mart.) Mattos e efeitos do extrato aquoso no perfil lipídico, glicêmico e na lipoperoxidação em ratos diabéticos. Rev. Bras. PI. Med., Campinas, v.18, n.1, supl. I, p.264-272, 2016.

JIMENEZ FILHO, D. L. Reatividade, temperatura corporal e taxa de concepção em fêmeas da raça Nelore submetidas à inseminação artificial em tempo fixo. 2013. 66 f. Dissertação (Mestrado em Qualidade e Produtividade Animal) - 
Faculdade de Zootecnia e Engenharia de Alimentos, Universidade de São Paulo, Pirassununga, 2013.

GUARATINI, T., et al. Ecotoxicologia. In: OGA, S.; ALMEIDA CAMARGO, M.M.; OLIVEIRA BASTITUZZO, J.A. (Ed.). Fundamentos de toxicologia. $3^{\underline{a}}$ ed. São Paulo: Atheneu Editora, 2008. Cap. 2.1, p. 125-141.

GWAY, N.; BERNARD, R. T. F. The effects of melatonin on sperm motility in vitro in Wistar rats. Andrologia, v.34, p.391-396, 2002. Disponível em: < https://onlinelibrary.wiley.com/doi/pdf/10.1046/j.1439-0272.2002.00522.x>. Acesso em 12/09/2018.

HALVAEI, I.; ROODSARI, H.R.S.; HARAT, Z.N. Acute Effects of Ruta graveolens L. on Sperm Parameters and DNA Integrity in Rats. J. Reprod. Infertil. v.13, n.1, p. 33-38, 2012.

HOLLENBACH, C. B. Estudo da toxicidade reprodutiva de duas formulações fitoterápicas comerciais contendo soja (Glycine max (L.) Merr) em ratos Wistar. 2008. 132 f. Dissertação (Mestrado). Porto Alegre. Programa de pósgraduação em de Ciências Veterinárias. Universidade Federal do Rio Grande do Sul. 2008. Disponível em:<

https://www.lume.ufrgs.br/bitstream/handle/10183/12704/000633368.pdf?sequence $=1>$. Acesso em: 12/09/2018

INSTITUTO NACIONAL DE CÂNCER JOSÉ ALENCAR GOMES DA SILVA (INCA). Posicionamento do instituto nacional de câncer acerca dos agrotóxicos. INCA/Ministério da Saúde. Disponível em:

$<$ http://www1.inca.gov.br/inca/Arquivos/comunicacao/posicionamento_do_inca_sob re_os_agrotoxicos_06_abr_15.pdf>. Acesso em: 27/05/2016.

JUNQUEIRA, L.C.; CARNEIRO, J. Órgãos associados ao trato digestivo. In $317-338$.

Histologia Básica. Rio de Janeiro: Guanabara Koogan, 2004. Cap. 16. p.

JUNQUEIRA, L.C.; CARNEIRO, J. Aparelho urinário. In Histologia

Básica. Rio de Janeiro: Guanabara Koogan, 2004. Cap. 19. p. 371 - 389.

JUNQUEIRA, L.C.; CARNEIRO, J. Aparelho reprodutor masculino. In

Histologia Básica. Rio de Janeiro: Guanabara Koogan, 2004. Cap. $\overline{21 . ~ p . ~} 415-$ 432.

KANDHARE, A. D., MUKHERJEE, A. A., BODHANKAR, S. L. Neuroprotective effect of Azadirachta indica standardized extract in partial sciatic nerve injury in rats: Evidence from anti-inflammatory, antioxidant and anti-apoptotic studies. EXCLI Journal, v.16, p.546-565. 2017.

KATTE, T., RAJYALAKSHMI, M.; ALADAKATTI, R. Assessment of azadirachtin-A, a neem tetranortritarpinoid, on rat spermatozoa during in vitro capacitation. Journal of Basic and Clinical Physiology and Pharmacology. v.0, n.0, p. 1 -9. 2018. Disponível em: < https://www.degruyter.com/view/j/jbcpp.ahead-of-print/jbcpp2017-0014/jbcpp-2017-0014.xml?intcmp=trendmd>.Acesso em: 26/05/2018.

KHILLARE, B; SHRIVASTAV, T.G. Spermicidal activity of Azadirachta indica (neem) leaf extract. Contraception. n. 68. p. 225-229. 2003.

KUNTZE, L.B. et al. Estudo comparativo dos efeitos do extrato de Ginkgo biloba L. e Panax ginseng C.A. Meyer na reprodução de ratos machos e fêmeas Wistar.

Revista Brasileira de Plantas Medicinais. UNESP, v. 14, n. 1, p. 34-42, 2012. Disponível em: <http://hdl.handle.net/11449/6457>. Acesso em: 31/01/2018. 
KOPROSKI, J. ; PACHALY, J.R. Contenção farmacológica do rato-do-bambu (Dactylomys dactylinus Desmarest, 1817) e relato de ocorrência da espécie na região Sul do Brasil. Pesq. Vet. Bras. v.37, n.6, p. 608-612, 2017. Disponível em: < http://www.scielo.br/pdf/pvb/v37n6/1678-5150-pvb-37-06-00608.pdf>. Acessado em: 18/01/2018.

LAUDANO, W.L.S. Cultura de calos e criopreservação de sementes de Cedrela fissilis VELLOZO (MELIACEAE). 2005. 148f. Dissertação (Mestrado) - Programa de Pós-Graduação em Biotecnologia da Universidade Federal de Santa Catarina. Florianópolis. 2005. Disponível em :< https://repositorio.ufsc.br/bitstream/handle/123456789/102810/224208.pdf?sequen $\mathrm{ce}=1$ \&isAllowed $=\mathrm{y}>$. Acesso em 09/01/2019.

LEITE, R.M.P. Efeitos tardios do tratamento neonatal com sertralina sobre a depressão experimental induzida em ratos Wistar. 2004. 75 f. Dissertação (Mestrado em Neuropsiquiatria e Ciências do comportamento) - Programa de PósGraduação em Neuropsquiatria da Universidade Federal de Pernambuco. 2004. Disponível em: < http://www.bdtd.ufpe.br/bitstream/handle/123456789/8635/arquivo8637_1.pdf?sequ ence $=1$ \&isAllowed $=y>$. Acessado em 18/01/2018

LEMONICA, I.P. Toxicologia da reprodução. In: OGA, S.; ALMEIDA CAMARGO, M.M.; OLIVEIRA BASTITUZZO, J.A. (Ed.). Fundamentos de toxicologia. $3^{a}$ ed. São Paulo: Atheneu Editora, 2008. Cap. 1.8, p. 104-113.

LIMA, V.M., et al. Estudo histopatológico do efeito da nicotina nos testículos e epidídimos de ratos. Histopathologic study of the effect of nicotine in testis and epididymis of rats. Rev Bras Clin Med. São Paulo. n.10, v.4, p.322-328. 2012. Disponível em: <http://files.bvs.br/upload/S/1679-1010/2012/v10n4/a3039.pdf>. Acesso em 22/01/2018.

LIMA PEDROSO, G. Avaliação da ingestão alimentar e do peso em ratos wistar machos tratados com extrato aquoso de llex paraguarienses. 2008. 33 f. Monografia. Universidade Federal do Rio Grande do Sul. Porto Alegre, 2008. Disponível em: < https://www.lume.ufrgs.br/bitstream/handle/10183/16559/000699455.pdf?sequence $=1>$. Acesso em 17/08/2018.

LIPINSKI et al. Avaliação do efeito anti-helmíntico e das alterações metabólicas em búfalos (Bubalus bubalis ) com administração da torta de Neem e do alho desidratado no Sul do Paraná. Revista Brasileira de Agroecologia, n.6, v.3, p. 168-175, 2011.

LIMA PEDROSO, G. et al. Efeito do extrato aquoso de llex paraguariensis sobre o metabolismo de ratos machos. Clinical \& Biomedical Research, [S.I.], v. 30, n. 3, 2010. Disponível em: <http://www.seer.ufrgs.br/hcpa/article/view/15407>. Acesso em 12/08/2018.

LISANTI, E., et al. The DNA and Spermatozoa Quality of Mice (Mus musculus albinus) after Administration Aqueous Leaves and Seeds Extract of Neem (Azadirachta indica A. Juss). Journal of Pharmacy. v.06, n.10, p.01-09, 2016.

LISANTi, E. et al. The effect of aqueous seed extract of neem (Azadirachta indica A. Juss) on liver histology of male mice (Mus musculus albinus). AIP Conference Proceedings. v. 2019. n. 1. p. 1-6, 2018. 
MACIEL, M.V.; et al. Extratos vegetais usados no controle de dípteros vetores de zoonoses. Rev. bras. plantas med., Botucatu, v. 12, n. 1, p. 105-

112, 2010. Disponível em:

$<$ http://www.scielo.br/scielo.php?script=sci_arttext\&pid=S1516-

05722010000100015\&lng=en\&nrm=iso >. Acessado em: 20/08/2018

MATA, J.S.; FERREIRA, R.L. Agrotóxico No Brasil - Uso e Impactos ao Meio Ambiente e a Saúde Pública. EcoDebate Site de informações, artigos e notícias socioambientais. Disponível em: <

https://www.ecodebate.com.br/2013/08/02/agrotoxico-no-brasil-uso-e-impactos-aomeio-ambiente-e-a-saude-publica-por-joao-siqueira-da-mata-e-rafael-lopesferreira/>. Acesso em: 11/07/2017

MARIZ, S. R. et al. Estudo toxicológico agudo do extrato etanólico de partes aéreas de Jatropha gossypiifolia L. em ratos. Rev. bras. farmacogn., João Pessoa , v. 16, n. 3, p. 372-378, 2006 . Acesso em:

$<$ http://www.scielo.br/scielo.php?script=sci_arttext\&pid=S0102-

695X2006000300015\&lng=en\&nrm=iso >. Acesso em 12/09/2018.

MBONGUE F. G., et al. Effect of the aqueous extract of dry fruits of Piper guineense on the reproductive function of adult male rats. Indian $\mathbf{J}$ Pharmacol. v.37, p.30-32. 2005.

MELLO CRUZ, A.P.; LANDEIRA-FERNANDEZ, J. Modelos animais de ansiedade e o estudo experimental de drogas serotonérgicas. Métodos em psicologia. Disponível em: <

http://www.nnce.org/Arquivos/Artigos/2012/cruz_etal_2012.pdf>. Acessado em: $18 / 01 / 2018$

MELO FILHO, G.A., RICHETTI, A. Aspectos socioeconômicos da cultura do milho - Milho-Informações técnicas. Dourados: EMBRAPA (EMBRAPA - CPAO), 1997. Circular Técnica, 13-38. Disponível em:

<https://ainfo.cnptia.embrapa.br/digital/bitstream/item/39000/1/CT5-97-Milho.pdf>. Acesso em: 11/10/2018

MENDEZ, M. C., et al. Intoxicação experimental com frutos de Melia azedarach (Meliaceae) em suínos. Pesq. Vet. Bras. Rio de Janeiro, v. 26, n. 1, p. 26-30, 2006.

MISHRA, R.K.; SINGH, S.K. Effect of aqueous leaf extract of Azadirachta indica on the reproductive organs in male mice. Indian Journal of Experimental Biology. v.43, p. 1093-1103. 2005. Disponível em: < http://nopr.niscair.res.in/handle/123456789/23279>. Acesso em 31/08/2018.

MOSAFERI, S. et al. Biophysical and biochemical characteristics of bactrian camel semen collected by artificial vagina. Theriogenology. v. 63 , n. 1, p.92-101, 2004.

MORANDI FILHO, W. J. et al. Ação de produtos naturais sobre a sobrevivência de Argyrotaenia sphaleropa(Meyrick) (Lepidoptera: Tortricidae) e seletividade de inseticidas utilizados na produção orgânica de videira sobre Trichogramma pretiosum Riley (Hymenoptera: Trichogrammatidae). Ci. Rural, v. 36, n. 4, p. $1072-$ 1078, 2006.

MOREIRA, M.D; et al. Uso de inseticidas botânicos no controle de pragas. In: VENZON, M.; PAULA JÚNIOR, T. J.; PALLINI, A. (Ed.). Controle alternativo de pragas e doenças. Viçosa: Epamig/CTZM, p. 89-120. 2006. 
MOREIRA, J.C.; et al. R. Avaliação integrada do impacto do uso de agrotóxicos sobre a saúde humana em uma comunidade agrícola de Nova Friburgo, RJ. Ciência \& Saúde Coletiva.Rio de Janeiro. v.7, n.2, 2002. Disponível em: < http://www.scielo.br/pdf/csc/v7n2/10249.pdf>. Acesso em 27/05/2016.

MORGAN, E.D. Azadirachtin, a scientific gold mine. Bioorganic \& Medicinal Chemistry. n.17, p.4096-4105. 2009. Disponível em:

$<$ https://www.sciencedirect.com/science/article/pii/S0968089608011346>. Acesso em 27/02/2018.

MOSSINI, S. A. G.; KEMMELMEIER, C. A árvore nim (Azadirachta indica A. Juss): Múltiplos usos. Acta Farmacêutica Bonaerense, v.24, p.139-148, 2005.

Disponível em: <

http://www.latamjpharm.org/trabajos/24/1/LAJOP_24_1_7_1_3E9IR6431G.pdf>. Acesso em: 11/10/2018.

MOURÃO, S. A. et al. Seletividade de extratos de nim (Azadirachta indica A. Juss.) ao ácaro predador Iphiseiodes zuluagai (Denmark \& Muma) (Acari: Phytoseiidae).

Neotrop. Entomol., Londrina , v. 33, n. 5, p. 613-617, 2004.

MUKHERJEE, S., GARG, S., TALWAR, G.P. Early post implantation contraceptive effects of a purified fraction of neem (Azadirachta indica) seeds, given orally in rats: possible mechanisms involved. Journal of Ethnopharmacology. v.3, n.67. p. 287 -296. Disponível em: <

https://www.sciencedirect.com/science/article/pii/S0378874199000689?via\%3Dihu b>. Acesso em: 10/01/2019.

MURTA, D.V.F., GOMES, V.C.L., MARTINEZ, L.C.R. A organização celular dos testículos de mamíferos. Rev Cient Eletrônica Med Vet. v.11, n.20, p.1-12. 2013.

NACIF DE ABREU, I.; MAZZAFERA, P. Effect of water and temperature stress on the content of active constituents of Hypericum brasiliense Choisy. Plant Physiol Biochem. v.43, n. 3, p.241-8. 2005. Disponível em:

<https://www.ncbi.nlm.nih.gov/pubmed/15854832>. Acesso em: 12/04/2018.

NIAZI, J.; et al. Anti-inflammatory, analgesic and antipyretic activity of aqueous extract of fresh leaves of Coccinia indica. Inflammopharmacology. v. 17, n. 14. p. 239 - 244. 2009. Disponível em: < https://www.ncbi.nlm.nih.gov/pubmed/19626277>. Acesso em 19/08/2018.

OFEM, O.E.; IKPI, D.E., ESSIEN,N.M. Increased bile flow rate and altered composition of bile induced by ethanolic leaf extract of Azadirachta indica (neem) in rats. Niger J Exp Clin Biosci. v. 1, p.18-22. 2013. Disponível em:

<: http://www.njecbonline.org/text.asp?2013/1/1/18/123958>. Acesso em: 18/09/2018.

OLIVEIRA, T.K.B.; et al. Análise do extrato aquoso de Arachis hipoagea L. no combate à dislipidemia e ao ganho ponderal de ratos Wistar submetidos à dieta hiperlipídica. Pesq. Vet. Bras. v.36, n.11, p.1121-1126. 2016. Disponível em: < https://www.ingentaconnect.com/content/doaj/0100736x/2018/00000036/00000011 /art00011 >. Acesso em 12/09/2018.

OJEWALE, A.O.et al. Testiculo Protective Effects of Ethanolic Roots Extract of Pseudocedrela kotschyi on Alloxan Induced Testicular Damage in Diabetic Rats.

British Journal of Medicine \& Medical Research. v.4, n.1, p. 548-563, 2014 
OLIVEIRA, V.; et al. Síndrome dos cílios imóveis. Abordagem diagnóstica e terapêutica de um caso raro de infertilidade. Rev Int Androl. v.1, n.4, p. 35-8. 2006.

ORGANIZAÇÃO MUNDIAL DA SAÚDE - OMS. WHO laboratory manual for the Examination and processing of human semen. Fifth edition. Genebra: WHO Press, 2010. Disponível em:

<http://apps.who.int/iris/bitstream/10665/44261/1/9789241547789_eng.pdf?ua=1>. Acessado em: 04/12/2017.

OSHIO, L.T.; et al. Efeito do Extrato de Ginkgo biloba (EGb) sobre a toxicidade sistêmica e órgãos do sistema reprodutor masculino de ratos Wistar adultos. Revista Interdisciplinar de Estudos Experimentais, v. 6, n. único, p. 7-14, 2014.

PANNOCCHIA, M.A.; et al. Estratégia efetiva de fixação do testículo de ratos Wistar para avaliar os parâmetros morfológicos e morfométricos do epitélio seminífero. ConScientiae Saúde. v. 7, n.2, p. 227-233. 2008.

PAZ, J.; et al. Hepatotoxicidade de plantas medicinais. xxxii. Ação da infusão de Achyrocline satureioides (lam.) d.c no rato. Investigação - Revista Científica da Universidade de Franca. Franca (SP) v. 5, n. 1/6, p. 154 -159. 2010. Disponível em: $<$

http://publicacoes.unifran.br/index.php/investigacao/article/viewFile/208/162>. Acesso em: 12/09/2018.

PESSOA, M. C. P. Avaliação da toxicidade do extrato contendo Nim (Azadirachta indica L.), andiroba (Carapa guianensis Aublet) e cana-de-açúcar (Saccharum officinarum L.) em ratas Wistar. 2009. 51 f. Dissertação (Programa de Pós-Graduação em Ciência Veterinária) - Universidade Federal Rural de Pernambuco, Recife. 2009.

PIRES JÚNIOR, H. B. Efeitos toxicológicos agudos de extratos de Melia azedarach (MELIACEAE) em ratos (Rattus novergicus), camundongos (Mus musculus) e Artemia salina 2010. 70 f. Dissertação (Mestrado em Ciências Agrárias - Veterinaria) - Universidade Federal de Goiás, Goiânia, 2010.

PIRES JÚNIOR, H. B.; BORGES, L.; SOUSA, L.; CUNHA, L.; LINO JÚNIOR, R.; MELO, D. et al. Avaliação da toxicidade aguda do extrato hexânico de frutos de Melia azedarach (Meliaceae) em camundongos. Ciência Animal Brasileira, v. 13, n. 4, p. 512-519, 2012.

POSSAMAI, F. Teste do nado forçado repetido: avaliação dos efeitos da imipramina sobre o comportamento e a neurogênese hipocampal dos ratos alojados em ambiente enriquecido. 2013. 88 f. Dissertação. (Mestrado em Ciências Fisiológicas) - Programa Multicêntrico de Pós-Graduação em Ciências Fisiológicas da Universidade Federal de Santa Catarina. Florianopólis. 2013. Disponível em: <https://repositorio.ufsc.br/handle/123456789/107269>. Acessado em: 18/01/2018

PORSOLT, R. M.; et al. Depression: a new animal model sensitive to antidepressant treatments. Nature, v.266, p. 730-732, 1977.

PRATES, H. T.; VIANA, P. A.; WAQUIL, J. M. Atividade de extrato aquoso de folhas de nim (Azadirachta indica) sobre Spodoptera frugiperda. Pesq. agropec. bras. Brasília, v. 38, n. 3, p. 437-439, 2003.

RAJAEI, Z., ET AL. Antihyperglycemic and antihyperlipidemic effects of hydroalcoholic extract of Securigera securidaca seeds in streptozotocin-induced diabetic rats. Advanced Biomedical Research, v.4, n.33, p. 1-15, 2015. 
Disponível em :< https://www.ncbi.nlm.nih.gov/pmc/articles/PMC4333482/>. Acesso em 25/05/2018.

REANMONGKOL, W., NOPPAPAN, T., SUBHADHIRASAKUL, S. J. Antinociceptive, antipyretic, and anti-inflammatory activities of Putranjiva roxburghii Wall leaf extract in experimental animals. Journal of Natural Medicines. v. 63, p. 290 -296, 2009. Disponível em: <https://doi.org/10.1007/s11418-009-0336-6>. Acessado em: 19/08/2018.

ROCHA, A.O.B. Efeito toxicológico do extrato hidroalcoólico de Pradosia huberi Ducke em ratos Wistar. Rev. Bras. Farm. v.93, n.3, pp. 371-378, 2012.

SANTOS, M. C. Avaliação do potencial tóxico reprodutivo do extrato de Cordia ecalyculata Vell: em ratos Wistar. 2014. 76 f. Dissertação (mestrado) Universidade Estadual Paulista Júlio de Mesquita Filho. Faculdade de Ciências e Letras de Assis, 2014. Disponível em: <http://hdl.handle.net/11449/121858>. Acesso em 31/08/2018.

SANTOS, M.M.R. Avaliação do consumo de diferentes concentrações de farinha de bocaiuva em ratos Wistar alimentados com dieta hipercalórica. 2017. 88 f. Dissertação (Mestrado). Programa de Pós-graduação em Saúde e Desenvolvimento na Região Centro-Oeste. Campo Grande. 2017. Disponível em: < https://posgraduacao.ufms.br/portal/trabalho-arquivos/download/4198>. Acesso em: 01/02/2018

SACHETTI, C. G., et al. Avaliação da toxicidade aguda e potencial neurotóxico do óleo-resina de copaíba (Copaifera reticulata Ducke, Fabaceae). Rev. bras. farmacogn., João Pessoa, v. 19, n. 4, p. 937-941, 2009. Disponível em: $<$ http://www.scielo.br/scielo.php?script=sci_arttext\&pid=S0102695X2009000600025\&Ing=en\&nrm=iso>. Acessado em: 18/01/ 2018.

SHARMA, S.K.; et al. Mechanism of Action of NIM-76: A Novel Vaginal Contraceptive from Neem Oil. Contraception. v.54, n. 6, p.373-378, 1996.

SATHIYARAj, K. et al. Spermicidal activity of Azadirachta indica (Neem) aqueous leaf extract on male Albino rats. International Journal of PharmTech Research. v.2 n.1 p.588-591, 2010.

SILVA, M. P. L.; et al. Bioatividade de Extrato Aquoso de Chenopodium ambrosioides L., no Controle de Toxoptera citricida Homóptera: Aphididae em citros. Cadernos de Agroecologia, [S.I.], v. 4, n. 1, p. 1-3, 2009. Disponível em: $<$ http://revistas.aba-agroecologia.org.br/index.php/cad/article/view/3470>. Acesso em: 20/08/2018.

SILVA, R. F. Efeitos da estimulação ultra-sônica sobre a espermatogênese de ratos pré-púberes e adultos: estudo experimental. 2007. $110 \mathrm{f}$. Dissertação (Mestrado em Bioengenharia) - Bioengenharia, Universidade de São Paulo, São Carlos, 2007. <http://www.teses.usp.br/teses/disponiveis/82/82131/tde-30072007152256/en.php>. Acesso em: 13/10/2018.

SILVA, V. C. L. Avaliação da toxicidade reprodutiva de ratas Wistar submetidas à ingestão do extrato etanólico das folhas de nim(Azadirachta indica A. Juss). 2010. 50 f. Dissertação (Programa de Pós-Graduação em Ciência Veterinária) - Universidade Federal Rural de Pernambuco, Recife. 2010.

SILVEIRA-BARBETTI, C.F. Avaliação seminal, dos receptores de D-manose e reação acrossomica em homens inférteis com varicocele. 2008. $92 \mathrm{f}$.Tese (Doutorado). Universidade Estadual de Campinas. Faculdade de Ciências 
Médicas. Campinas. 2008. Disponível em:

<http://repositorio.unicamp.br/jspui/handle/REPOSIP/313699>. Acesso em 12/09/2018.

SOUSA, P.V., et al. Avaliação morfológica dos espermatozóides de ratos wistar tratados com extrato diclorometânico de folhas de bacupari Cheiloclinium

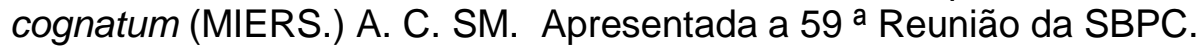

SATYANARAYANA, K., et al. Molecular approach to identify antidiabetic potential of Azadirachta indica. Journal of Ayurveda and Integrative Medicine, v. 6, n.3, p.165-174. 2015. Disponível em:

<https://www.ncbi.nlm.nih.gov/pmc/articles/PMC4630690/\#!po=2.08333>.

Acessado em: 24/04/2018.

SHARPE, R.M. Lifestyle and environmental contribution to male infertility. British Medical Bulletin. v.56, n. 3, p. 630-642, 2000. Disponível em:

$<$ https://doi.org/10.1258/0007142001903436>. Acessado em 26/07/2018

SCHUMACHER, M. Anti-inflammatory, pro-apoptotic, and anti-proliferative effects of a methanolic neem (Azadirachta indica) leaf extract are mediated via modulation of the nuclear factor-k B pathway. Genes Nutrition. v. 6, p. $149-160.2011$.

Disponível em: <

https://genesandnutrition.biomedcentral.com/articles/10.1007/s12263-010-0194-6 >. Acesso em 17/08/2018.

SILVA, A.P. et al.; Ácidos graxos plasmáticos, metabolismo lipídico e lipoproteínas de ratos alimentados com óleo de palma e óleo de soja parcialmente hidrogenado. Rev. Nutr. Campinas, no 18, v.2, p. 229-237.2005. Disponível em: < http://www.scielo.br/pdf/rn/v18n2/24379.pdf>. Acesso em 13/05/2018

SILVA MADUREIRA, A.M.A. Espermograma. Puc- Minas. p. 85 -90. Disponível em: $<$

http://www1.pucminas.br/imagedb/documento/DOC_DSC_NOME_ARQUI2013091 6153400.pdf>. Acesso em 22/01/2018.

SILVA LIMA, C. Estudo da toxidade não clínico em ratos submetidos ao tratamento com óleoresina de Copaifera duckei dwyer (subcrônico e reprodutivo).2014, $265 f$.

Tese (doutorado) - Fundação Universidade Federal do Amapá, Programa de PósGraduação em Biodiversidade Tropical.2014. Disponível em: < http://www2.unifap.br/ppgbio/files/2012/02/TESE-COM-FICHACATALOGRAFICA_CLARISSA.pdf>. Acesso em 21/06/2017

SILVA, S.L., et al. Avaliação da toxicidade aguda pré-clínica do extrato metanólico das cascas do caule de Parahancornia amapa (Apocynaceae). Acta Amazônica. vol. 46, n-1, 2016. Disponível em: < http://www.scielo.br/pdf/aa/v46n1/1809-4392aa-46-01-00073.pdf>. Acesso em: 20/06/2017.

\footnotetext{
SOCIEDADE BRASILEIRA DE PATOLOGIA CLÍNICA/MEDICINA LABORATORIAL. Recomendações da Sociedade Brasileira de Patologia Clínica/Medicina Laboratorial (SBPC/ML): coleta e preparo da amostra biológica. - Barueri, SP: Manole: Minha Editora, [487-]. Disponível em: < http://www.sbpc.org.br/upload/conteudo/livro_coleta_biologica2013.pdf>. Acesso em 22/01/2018.
}

SONMEZ, M.; TURK, G.; YUCE, A. The effect of ascorbic acid supplementation on sperm quality, lipid peroxidation and testosterone levels of male Wistar rats.

Theriogenology. v. 63 , p.2063-72. 2005 
SOUZA CHAGAS, A.C. Controle de parasitas utilizando extratos vegetais. Revista Brasileira de Parasitologia Veterinária, v.13, supl.1, p.156-160, 2004

SUBAPRIYA, R.; S. NAGINI. Medicinal Properties of Neem Leaves: A Review.

Curr. Med. Chem. - Anti-Cancer Agents. v. 5, p. 149-156, 2005.

VIANA, P.A.; RIBEIRO, P.E.A. Efeito do extrato aquoso de folhas verdes de nim (Azadirachta indica) e do horário de aplicação sobre o dano e o desenvolvimento larval de Spodoptera frugiperda (j.e. smith, 1797) (Lepidoptera: noctuidae) na cultura do milho. Revista Brasileira de Milho e Sorgo, v.9, n.1, p. 27-37, 2010.

VIANA, P.A.; PRATES, H.T.; RIBEIRO, P.E.A. Uso do Extrato Aquoso de Folhas de NIM para o Controle de Spodoptera frugiperda na Cultura do Milho.

Circular Técnica 88 EMBRAPA. 5 . Disponível em: < https://www.embrapa.br/documents/1344498/2767891/uso-do-extrato-aquoso-defolhas-de-nim-para-o-controle-de-spodoptera-frugiperda-na-cultura-domilho.pdf/f1d204a5-fa0d-4818-b859-59d30d039605 >. Acesso em 17/08/2018.

WEBER, A.L. Comparação entre os valores seminais e a fertilidade do rato. Florianópolis: Universidade Federal de Santa Catarina. 1998. Disponível em: <https://core.ac.uk/download/pdf/30392344.pdf>. Acessado em: 02/02/2018.

WINTOLA, O.A., SUNMONU, T.O., AFOLAYAN, A.J. The effect of Aloe ferox Mill. in the treatment of loperamide-induced constipation in Wistar rats. BMC

Gastroenterology. v. 10, n. 95, p. 1-5, 2010. Disponível em: < https://bmcgastroenterol.biomedcentral.com/articles/10.1186/1471-230X-10-95>. Acesso em 17/07/2018. 